\title{
A INCORPORAÇÃO DOS PRINCÍPIOS E DAS DIRETRIZES DO SISTEMA ÚNICO DE SAÚdE AOS CURSOS DE FORMAÇÃO DO AUXILIAR DE ENFERMAGEM: \\ O Projeto Larga Escala no período de 1989 a 1992
}

\author{
ALVA HELENA DE ALMEIDA
}

Dissertação de Mestrado apresentada ao Departamento de Prática de Saúde Pública da Universidade de São Paulo para obtenção do Grau de Mestre em Saúde Pública

Área de concentração: Serviços de Saúde Pública

ORIENTADORA: PROF”. DRª. CÁSSIA BALDINI SOARES

Săo Paulo

onnn 
UNIVERSIDADE DE SÃ0 PAULO

FACULDADE DE SAÚDE PÚBLICA

SERVICQO DE APRIMORAMENTO

Av. Dr. Arnaldo, 715 - CEP $01246-904$ - São Paulo - Brasil

Telefones: (55-11) 30667734 - fone/fax (55-11) 30647314

ATA DA SESSÄO PÚBLICA DE ARGÜIÇÄO E DEFESA DA DISSERTAÇÄO DE MESTRADO APRESENTADA PELA CANDIDATA AO TITULO DE "MESTTRE EM SAUUDE PÚBLICA" - AREA DE CONCENTRAÇÃO SERVIÇOS DE SAUUDE PÚBLICA - ALVA HELENA DE ALMEIDA.

Aos quatorze dias do mês de dezembro de 2000, às 9h30min, realizou-se na Sala Prof. Diógenes Augusto Certain da Faculdade de Saúde Pública da Universidade de São Paulo, a sessão pública para argüiçäo e defesa da dissertação intitulada "A INCORPORAÇÃO DOS PRINCIPIOS E DAS DIRETRIZES DO SISTEMA ÚNICO DE SAÚDE AOS CURSOS DE FORMAČÃO DO AUXILIAR DE ENFERMAGEM: O PROJETO LARGA ESCALA NO PERIODO DE 1989 A 1992", apresentada por Alva Helena de Almeida, candidata ao título de "Mestre em Saúde Pública" - área de concentraçăo Serviços de Saúde Pública. A Comissão Julgadora foi constituida pelos membros Professora Marina Peduzzi - Departamento de Orientaçăo Profissional da EE/USP, Professor Paulo Capel Narvai - Departamento de Prática de Saúde Pública da FSPIUSP e Professora Cássia Baldini Soares Departametno de Enfermagem em Saúde Coletiva da EE/USP - (Orientadora e Presidente da Comissão). A Comissăo Julgadora passou à argüição pública da candidata. Encerrados os trabalhos de argüiçäo, os examinadores deram 0 parecer final:

Professora Doutora Marina Peduzzi Aprovado(a) Reprovado

Professor Doutor Paulo Capel Narvai Aprovado(a) $\bar{X}$ Reprovado $\square$

Professora Doutora Cássia Baldini Soares Aprovado(a) $\bar{x}$ Reprovado

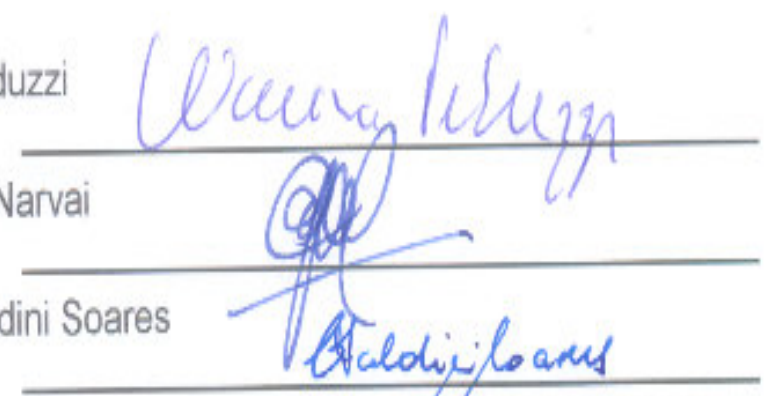

Presidente da Comissâo Examinadora

- orientadora - 


\section{ERRATA}

Nos agradecimentos onde se lê Marie Ozuma, leia-se Marie Azuma.

À tista de siglas apresentada acrescento as seguintes:

CEFORH - Centro de Formação de Recursos Humanos

ETSUS - Escola Técnica de Saúde para o SUS

IPTU - Imposto Predial Territorial Urbano

LOS - Lei Orgânica da Saúde

MS - Ministério da Saúde

OMS - Organizaçăo Mundial de Saúde

PLE - Projeto Larga Escala

PREV-SAÚDE - Programa Nacional de Serviços Básicos de Saúde

PT - Partido dos Trabalhadores

NRP - Núcleo Regional de Planejamento

SAR - Secretaria das Administrações Regionais

SUDS - Sistema Unificado e Descentralizado de Saúde

Ainda com relaçăo à lista de siglas apresentada,

onde se lê, CEPAL - Comissăo Econômica das Naçōes Unidas leia-se Comissão Econômica das Nações Unidas para a América Latina;

onde se lê OPAS - Organização Panamericana de Saúde, leia-se Organização Pan-americana de Saúde;

onde se lê PIDA - Programa de Integraçăo Docente Assistencial, leia-se Programa de Integraçăo Docente-Assistencial.

Na p.10, parágrafo 1, onde se lê Instituto Nacional de Previdência Social INAMPS - leia-se Instituto Nacional de Assistência Médica da Previdência Social INAMPS.

Na p.52, nota de rodapé(6) $12^{\mathrm{a}}$ linha onde se lê 5) Para OLIVIERA (1966, p.33) leia-se 5) Para OLIVEIRA (1966, p.33). 
Na p.59, parágrafo 2, penúltima linha onde se lê (...) enfermeiras que participaram do programa de treinamento e que não forma incluídas (....), leia-se, enfermeiras que participaram do programa de treinamento e que näo foram incluídas (....).

Na p.81, parágrafo 1 onde se lê atendentes de consultório dentário - $A C D$, Técnico de Higiene Dental - THD (....), leia-se Atendentes de Consultório Dentário - ACD, Técnico em Higiene Dental - THD (...).

Na p.97, parágrafo 4 onde se lê Nosso dados revelam-se (...) leia-se Nossos dados revelam-se (....).

$\mathrm{Na}$ p.101, parágrafo 2 onde se lê (...) determinado curso se promoveu determinados insites, mudanças e tal, (...) leia-se (....) determinado curso se promoveu determinados insights, mudanças e tal (...).

Na p.102, parágrafo 2 onde se lê Muitos foram os esforços empreendidos, até que - CEFOR se vinculasse a uma Escola da rede municipal de ensino (...) leia-se Muitos foram os esforços empreendidos, até que o CEFOR se vinculasse à Escola Municipal de Primeiro e Segundo Grau - EMPSG - Derville Allegretti da rede de ensino (....).

Na p.106, parágrafo 1 onde se lê '( ....) além das tarefas de formaçăo no 'stritu sensu (...), leia-se (...) além das tarefas de formação no stricto sensu (....)

Na p.116, parágrafo 6 onde se lê (...) entăo esse projeto veio de encontro com essa proposta anterior leia-se (....) então esse projeto veio de encontro (sic) com essa proposta anterior.

Na página 132, na última linha onde se lê (...) os de nivel superior, leia-se (...) os de nivel universitário 
Aos meus pais, (ele in memoriam) pela nobreza dos valores éticos, sedimentados fora da escola, e transmitidos aos filhos, apesar das adversidades da vida;

Aos meus amigos negros - Maira Inês, Gevanilda, Maria José, Fernanda, Batista - que triunfaram neste caminho da pós-graduação, no qual me empenhei em segui-los, superando barreiras estabelecidas, apesar da democracia racial 
Agradecimentos às mulheres, maioria absoluta nos serviços de saúde:

A Isabel dos Santos, por constituir-se em referência nacional, nessa longa luta em defesa da qualificação dos trabalhadores do setor saúde e do pessoal do nivel elementar e médio, em particular;

À Maria do Carmo Sales Monteiro, por representar, a referência local, da competência e da autodidaxia frente a problemática dos recursos humanos em saúde com quem sempre, procurei aconselhar-me;

Às colegas de trabalho, Pasqualina e Suely, que solidariamente, me esclareceram muitas dúvidas nessa descoberta;

À Maria Celeste que mesmo distante do CEFOR e da equipe, ouviu-me atentamente, sugeriu, questionou;

À Marie Ozuma, pelo companheirismo, tão logo iniciei a pós-graduaçăo;

À Alice Derntl, a primeira Orientadora, pela tolerância a minha desorientação;

A Joana Azevedo Silva, por fornecer-me informaçōes preciosas sobre algumas das pesquisas realizadas sobre este tema;

À Milta Torres, pela generosidade;

À Suzy, pela solidariedade;

À Elizete do CEFOR, Sérgio e Evellyn - EEUSP - por socorrer-me com a digitação;

À Orientadora, Cássia Baldini, pelo acolhimento e pelo respeito profissional. 
Aos profissionais que viabilizaram, mediante os seus depoimentos, a coleta de dados desta pesquisa.

Aos homens, minoria nesse contexto, porém importantes:

Ao João Palma por transmitir tamanha segurança e me fornecer aquela informação "chave" no momento certo;

Ao João Marcolan pela amizade e pelo incentivo;

Aos rapazes da 'gráfica' - Eni, Marcelo e Carlos - pela colaboração

Ao Jorge pela bondade. 


\begin{abstract}
The change of São Paulo city administration in 1989, had ordered, particularly to the health sector, many innovations related to the management of the health services aiming at the implementattion of the Brazilian Public Health System - BPHS -. To accomplish that, one of the main strategies was the qualfication of health workers. This qualitative study has the objective of analyzing how the political principles of the BPHS were incorporated to the courses promoted to form nurses auxiliaries through the Large Scale Formation program. Using the concepts that had nurtured the construction of the health system political principles, derived from the Sanitary Reform movement, the methodology of the study consisted of: 1) a document research; 2 ) interviews with program coordinators of the central and regional levels of the Municipal Department of Health. Data analysis allows to recognize that: 1 ) the policies of this administration were compromised with the Sanitary Reform movement: it had prioritized the qualification of health workers that did not had this opportunity before; and it had adopted a pedagogical practice in order to conduct a process of transformation of the health agents towards their health practice and their rights as workers and citizens; 3) most of the coordinators were motivated to develop this qualification proposal and they had viewed the process as an important tool to implement the public health system; 4) the regional level coordinators had a limited understanding of the qualification process, isolating the technical from the political dimension.
\end{abstract}




\section{SIGLAS UTILIZADAS}

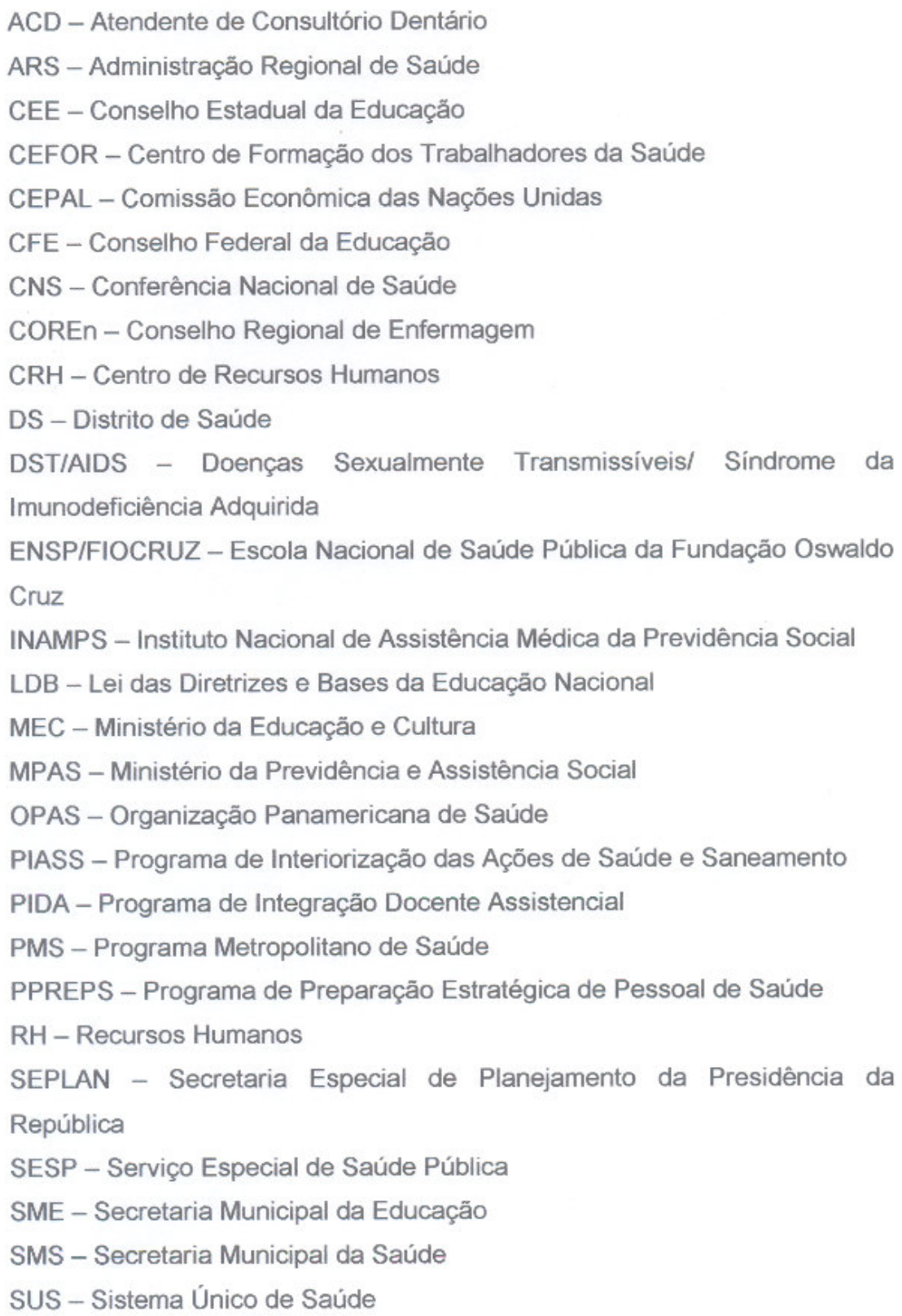




\section{ÍNDICE GERAL}

1. INTRODUÇÃO: A QUALIFICAÇÃO DOS TRABALHADORES DA SAÚDE E O GOVERNO MUNICIPAL NO PERÍDO DE 1989 A 1992

1.1. O objeto e o problema de estudo

1.2. Os objetivos e a finalidade do estudo SANITÁRIA E DO SISTEMA ÚNICO DE SAÚDE

2.1. Princípios e diretrizes políticas do SUS

2.1.1. Descentralização

23

2.1.2. Universalidade

2.1.3. Eqũidade

2.1.4. Integralidade

2.1.5. Participação popular

2.2. A política de formação de recursos humanos em saúde no

2.2.1. Antecedentes históricos

2.2.2. As transformações sociais da década de 80 e o PLE

2.2.3. As atendentes de enfermagem e o PLE

3. TRAJETÓRIA METODOLÓGICA DA PESQUISA 56

3.1. Procedimentos para a apreensão do objeto 56

3.2. As entrevistas $\quad 57$

3.2.1. Os sujeitos pesquisados $\quad 57$

3.2.2. Os roteiros de entrevista 59

3.3. Análise dos resultados 61

4. O PLANO DA POLITICA: APROPRIAÇÃO DOS PRINCIPIOS E 63 DIRETRIZES DO SUS NO CONTEXTO DA GESTÃO MUNICIPAL DO PT

4.1. A descentralização e o governo Luíza Erundina 63

4.2. A universalidade e o governo Luíza Erundina 65

4.3. A integralidade e o governo Luíza Erundina 66

4.4. A eqüidade e o governo Luiza Erundina 67

4.5. A participação popular e o governo Luíza Erundina 68

4.6. O Centro de Formação dos Trabalhadores da Saúde como espaço 71 institucional de mudança

4.7. O Projeto Larga Escala como estratégia de qualificação de pessoal de 76 nível médio

4.8. A metodologia problematizadora como eixo de reordenação do processo 82 educativo 
5. O PLANO DA PRÁTICA: A COMPREENSÃO DOS ENVOLVIDOS NO PROCESSO DA QUALIFICAÇÃO DOS TRABALHADORES DE SAÚDE

5.1. A opinião dos coordenadores do nível central 88

5.1.1. Quanto aos princípios e diretrizes do SUS 88

5.1.2. Quanto à política de recursos humanos 92

5.1.3. Quanto ao Centro de Formação e ao Projeto Larga Escala 98

5.1.4. Quanto ao Centro de Formação dos Trabalhadores de Saúde 103

5.2. Opinião dos coordenadores regionais 111

$\begin{array}{ll}\text { 5.2.1. Quanto aos princípios e diretrizes do SUS } & 114\end{array}$

6. CONSIDERAÇÖES FINAIS: MAIS PARA TÉCNICO DO QUE 135 PARA POLÍTICO

6.1. Os princípios, as diretrizes do SUS e o PLE para o nivel central 135

6.2. Os princípios, as diretrizes do SUS e o PLE para o nível regional 137

7. REFERENCIAS BIBLIOGRÁFICAS 143

ANEXOS $\quad 157$

$\begin{array}{lr}\text { ANEXO } 1 & 160\end{array}$

$\begin{array}{lr}\text { ANEXO } 2 & 173\end{array}$

$\begin{array}{ll}\text { ANEXO } 3 & 187\end{array}$ 


\section{INTRODUÇÃO: A QUALIFICAÇÃO DOS TRABALHADORES DA SAÚDE E O GOVERNO MUNICIPAL NO PERÍODO 1989- 1992}

A vitória nas eleições municipais à prefeitura de São Paulo da candidata de oposição Luiza Erundina em 1988, se concretizou pelo significativo apoio dos movimentos populares. A sua trajetória política dentro do partido - Partido dos Trabalhadores (PT) - e particularmente, em defesa das lutas sociais junto aos movimentos sociais organizados favoreceu a sua vitória nas urnas (JACOBI 1991).

Nesse governo municipal, estavam colocados dois grandes objetivos: governar para a maioria com uma inversão de prioridades, e governar com a participação popular (SADER 1992, p.23).

A plataforma político-eleitoral e o programa de governo, defendido na campanha, tiveram assento numa proposta democrática e popular de governo, e pressupunham "um compromisso de inverter prioridades, reorientando os investimentos públicos de modo a atender prioritariamente às necessidades e aos direitos sociais da população “(JACOBI 1991).

Dessa forma, constituíram-se algumas marcas desse modo de governar:

- a participação popular - "tanto por garantir a aplicação do plano de governo, tanto por sustentar uma articulação entre democracia representativa e as formas diretas de representação da sociedade civil”, buscando garantir uma participação efetiva nas decisões, no controle e fiscalização da ação governamental (BITTAR 1992, p.22);

- a inversão de prioridades - que buscava direcionar os principais investimentos para as áreas mais carentes além, de "recuperar a qualidade do serviço público e garantir a igualdade de acesso aos serviços urbanos básicos” (BITTAR 1992, p.22).

Ao assumir a prefeitura, Luiza Erundina e sua equipe encontraram uma situação econômica e administrativa totalmente adversa. Vigorava no país um novo plano econômico, herdou-se dos governos anteriores uma dívida global de quase um bilhão e meio de dólares, empréstimos obtidos junto ao governo federal, ou no 
exterior, foram cortados, provocando a paralisação de obras na cidade. "O governo priorizou o saneamento das finanças municipais, a recuperação da situação salarial do funcionalismo e a reforma de equipamentos abandonados pela gestão anterior como creches, escolas, hospitais, praças e parques" (SADER 1992, p.25).

"Uma decisão do governo para viabilizar a administração local consistiu em recolher impostos de quem tem mais e dar benefícios a quem tem menos" (SADER 1992; KOWARICK e SINGER 1993, p.205).

No caso do projeto do Imposto Predial Territorial Urbano - IPTU da prefeitura de São Paulo, "tratou-se simplesmente de aplicar o princípio democrático da progressividade dos impostos à propriedade imobiliária", valendo-se da extensão das áreas, dos serviços urbanos e outras vantagens de sua localização. Com esse mecanismo progressivo, a prefeitura buscou simplesmente recuperar o poder de arrecadação do IPTU, o qual estava em declínio desde 1979, cobrando o imposto dos mais afortunados e "aplicando o dinheiro recolhido em áreas como transporte, moradia, saúde e educação - serviços cruciais para a maioria da população" (SADER, 1992 p.110-1; KOWARICK e SINGER 1993, p.206).

Houve um avanço indiscutível no que se refere à arrecadação, e também no que diz respeito ao gasto. $\mathrm{O}$ aumento no dispêndio com a área social refletiu-se, sobretudo, em resultados positivos no setor de educação, e na área da saúde. Ao longo de toda a administração cerca de $48 \%$ dos recursos orçamentários foram destinados à área social (COHN 1991).

“A canalização de recursos efetivada entre 1989 a 1992 parece ter imprimido um avanço na direção de uma política municipal capaz de atender às necessidades de educação e saúde dos grupos de baixa renda” (KOWARICK e SINGER1993, p.208).

"A Secretaria de Saúde foi a que recebeu mais verbas em 1991, e teve uma dotação grande também em 1992” (KOWARICK e SINGER 1993, p.208); os recursos orçamentários destinados à saúde foram gradativamente aumentados no decorrer da gestão, variando de $10,6 \%$ no primeiro ano a $15,4 \%$ no último ano (COHN 1991).

No setor saúde, as principais propostas dessa administração estavam “centradas na participação popular, na descentralização, e na democratização dos serviços de saúde, tendo por objetivo a implementação do Sistema Único de Saúde 
na cidade de São Paulo" (COHN e col.1993). A implementação desse sistema significa a descentralização das ações de saúde para a gerência do município, "implica gestão democrática, criação do Conselho Municipal e participação da sociedade nos vários níveis de decisão" (BITTAR 1992, p.139).

Em abril de 1989, a Secretaria de Higiene e Saúde passou a chamar-se Secretaria Municipal da Saúde - SMS e, foi subdividida em 10 Administrações Regionais de Saúde, ARSs. Cada ARS ganhou maior autonomia políticoadministrativa, passou a gerenciar todos os tipos de equipamentos municipais de saúde situados dentro da sua área geográfica o que posteriormente viabilizou a implantação dos Distritos de Saúde - DS (TELESI JUNIOR 1998, p. 43).

Em todas as instâncias administrativas foram instituídos canais de participação dos usuários e dos trabalhadores de saúde. Para SINGER (1996, p.239), a diretriz fundamental que marcou o governo da prefeita Luiza Erundina foi $a$ democratização do Estado, inaugurando um novo estilo de relacionamento entre prefeitura e munícipes.

Para JACOBI (1991, p.35) e KOWARICK e SINGER (1993, p.216), a metamorfose mais significativa que se verificou nessa gestão foi relativa ao trato da Coisa Pública principalmente no que se refere aos procedimentos prévios do processo decisório das ações governamentais, com ênfase nos mecanismos de participação e controle populacional. Além disso, buscou-se implementar medidas efetivas voltadas "para a valorização do servidor municipal, não só no plano salarial mas na gestão dos recursos humanos, apesar de todos os entraves existentes e do burocratismo da máquina administrativa municipal”.

A gestão dos recursos humanos foi vista como sendo um dos maiores desafios devido à sua extrema complexidade (COHN e col. 1993). Para esse modo de governar, "a prestação de serviços de saúde (...) [deve ser feita] fundamentalmente através de recursos humanos qualificados. Não há nada que substitua a ação do profissional qualificado" (BITTAR 1992, p.144).

Esse entendimento quanto a importância da valorização do trabalhador dos serviços públicos oferecidos à população, não foi privilégio do setor saúde. O setor educacional também pode otimizar os resultados da Secretaria Municipal da Educação - SME, mediante uma atuação pautada nas diretrizes da democratização da 
gestão das escolas, na democratização do acesso do aluno ao ensino municipal, na melhoria da qualidade de ensino e na implantação de programas especiais de educação de jovens e adultos (SADER, 1992).

A escolha dos Secretários desses setores esteve comprometida com um determinado perfil profissional, político e ético, que viabilizasse os seus respectivos projetos. No setor saúde, através do médico sanitarista com reconhecida participação no Movimento de Saúde, além de efetiva contribuição para a Reforma Sanitária, o deputado federal Dr. Eduardo Jorge, e na educação, o notável educador, Paulo Freire, internacionalmente conhecido pela sua contribuição à prática pedagógica no $3^{\circ}$ mundo com a alfabetização de adultos (FREIRE e SHOR, 1986).

$\mathrm{O}$ ingresso de profissionais aos serviços, fez-se unicamente através dos concursos públicos, de acordo com o que foi estabelecido na Constituição. A política de recursos humanos definida para a Secretaria Municipal de Saúde norteou-se pela profissionalização dos trabalhadores buscando a garantia de alguns direitos, entre eles, o da educação e da profissionalização.

Essa gestão municipal, frente ao compromisso de implantar o Sistema Único de Saúde - SUS -, tomara a decisão de desenvolver uma política estratégica de Recursos Humanos (RH) voltada para a qualificação do pessoal de nível médio para o trabalho em saúde, com reconhecimento pelo sistema formal de ensino, ao mesmo tempo que se propunha a dar sustentação técnica e gerencial ao novo modelo de atenção instalado.

O Centro de Formação dos Trabalhadores - CEFOR -, na condição de uma estrutura administrativa e de apoio técnico-pedagógico, ligado ao Centro de Recursos Humanos da Secretaria Municipal de Saúde de São Paulo, incorporou essa estratégia de formação de pessoal auxiliar e implementou cursos de qualificação dos servidores nas Administrações Regionais de Saúde do município, a partir de 1990.

O desenvolvimento dos cursos de formação do Projeto Larga Escala, denominado apenas como Larga Escala ou ainda, o PLE representou um dos alicerces de uma política de RH da SMS cujos "princípios da valorização, profissionalização e participação dos funcionários, buscavam produzir mudanças na mentalidade e nas ações visando uma postura de respeito e dignidade ao trabalho e 
aos trabalhadores em saúde, de acordo com os interesses e necessidades da população" (SECRETARIA MUNICIPAL DA SAÚDE, 1989, p.1-2 ).

\subsection{O objeto e o problema de estudo}

O objeto deste estudo constitui-se nas relações estabelecidas entre o projeto de formação de pessoal em serviço - o PLE - e as políticas de saúde implantadas pela administração municipal.

As decisões políticas da gestão municipal de que estamos tratando, referentes à reorganização dos serviços de saúde, mediante a incorporação de novos profissionais e de novas práticas de saúde, através de concursos públicos e do reequacionamento de pessoal, colocaram para os profissionais de saúde da rede municipal, a necessidade de se posicionar frente a sua integração nesse processo.

$\mathrm{Na}$ condição de trabalhadores engajados nesses serviços de saúde, estivemos diante de várias oportunidades de discussão e posicionamento quanto a uma nova atribuição definida para as enfermeiras: desenvolver cursos de formação dos auxiliares de enfermagem, durante a jornada de trabalho, através do Projeto Larga Escala. Particularmente, na encarregatura de uma Unidade de Emergência, indagávamo-nos o quanto as condições de trabalho existentes não permitiriam assumir, de forma adequada e simultaneamente, um encargo de tamanha abrangência e complexidade.

Nesse contexto, fomos convidados para compor o quadro de pessoal do Centro de Formação dos Trabalhadores da Saúde com a responsabilidade de coordenar a capacitação do pessoal auxiliar das equipes do Atendimento Préhospitalar junto ao Núcleo de Desenvolvimento ${ }^{1}$ desse centro. Na condição de técnica especialista de uma área assistencial, tal proposta pareceu-nos adequada à nossa formação e experiência: era plausível estabelecer as relações entre o conhecimento por nós acumulado e os novos referenciais que advinham da nova proposta e, portanto, havia o potencial para desenvolver uma prática de ação educativa para o pessoal auxiliar das equipes de saúde.

\footnotetext{
${ }^{1}$ Este núcleo desenvolve cursos para a capacitação técnica e gerencial dos profissionais envolvidos nas práticas dos serviços.
} 
Ao mesmo tempo, constatávamos a complexidade do PLE em termos: do envolvimento de profissionais (alunos e instrutores); de providências administrativas; de ações componentes, das intercomunicações necessárias; dos eventos a serem desenvolvidos, entre outros. Experimentamos, em diferentes momentos, sentimentos de admiração e de certa perplexidade ao tentar compreender o processo de implementação do PLE, que provocava uma série de conflitos.

$\mathrm{O}$ fato é que, somente depois de cinco anos desenvolvendo atividades junto ao CEFOR, tivemos oportunidade de fazer um curso de Capacitação Pedagógica para Instrutores e Monitores do PLE, logo em seguida, vindo a desenvolver a função de Monitora de um curso de Especialização para Enfermeiras na área de Saúde Pública. Naquele momento passamos a compreender, de maneira diferenciada, a responsabilidade do profissional da área de saúde frente à qualificação do pessoal auxiliar na perspectiva da compartilha do saber, favorecendo assim o alcance da qualidade do trabalho realizado pela equipe de saúde.

Finalmente, a partir de 1996, ano de início de nossa qualificação no nível de mestrado, viemos a compor a equipe do Núcleo de Formação ${ }^{2}$ do CEFOR, o que nos aproximou da possibilidade de compreender as relações entre o projeto de formação dos auxiliares de enfermagem e as diretrizes da gestão municipal de saúde no período de 1989 - 1992.

O PLE representava no discurso e, certamente na prática, a efetiva experiência dos serviços de saúde em realizar a capacitação do pessoal auxiliar, na perspectiva da adequação à realidade determinada pela reorganização estrutural dos serviços e pela incorporação de diferentes práticas de saúde.

Recorremos então à pesquisa bibliográfica buscando o suporte teórico para compreender as políticas e estratégias de formação de RH para o setor saúde, restringindo-nos à temática da "Formação de RH para o SUS".

Na tentativa de objetivar um pouco mais o nosso estudo, estabelecemos um recorte na área temática, enfocando as discussões a respeito da Formação de $R H$ de nível médio, particularmente, na área de enfermagem, uma vez que os trabalhadores dessa área representavam, nos anos 80 , cinqüenta por cento da força de trabalho

\footnotetext{
${ }^{2}$ Este núcleo desenvolve os cursos de qualificação profissional do pessoal do nível médio.
} 
do setor saúde (MEDICI 1987; SANTOS, e col. 1988;VIEIRA e SCUCATO 1988; TORRES 1994).

Essa característica da composição da força de trabalho do setor saúde foi resultado do jogo de interesses econômicos e políticos dessa área na década anterior, que gerou a expansão da rede privada assistencial, além dos inúmeros ambulatórios de especialidades e da rede básica de saúde no sub-setor público, mediante a oferta de emprego para um enorme contingente de pessoal, sem nenhuma qualificação para o trabalho em saúde (MEDICI 1987; SANTOS e col. 1988).

O SUS, tendo seu marco de formação na VIII Conferência Nacional de Saúde (CNS) que reconheceu os encaminhamentos do movimento da Reforma Sanitária Brasileira como postulante de um conceito ampliado de saúde e de uma nova ordenação do sistema, demandou o estabelecimento de uma nova política de formação de RH que respondesse às novas exigências dos serviços de saúde.

Para compreender a situação da novidade na qualificação dos trabalhadores de nível médio em saúde, recuperaremos, brevemente, os dados do período anterior à VIII CNS, caracterizado pela desarticulação entre as necessidades de saúde e as características da formação e que, progressivamente, foi tentando incorporar os ideais da reforma à problemática da formação de RH em saúde.

De acordo com PAIM (1994), o Programa de Preparação Estratégica de Pessoal de Saúde - PPREPS - foi uma primeira experiência expressiva no sentido de promover a formação de pessoal de saúde articuladamente aos serviços de saúde no Brasil. O Programa teve origem em 1974, mas com início efetivo em 1976, através dos Ministérios da Saúde e da Educação, com a cooperação da Organização Panamericana de Saúde (OPAS)/Organização Mundial de Saúde (OMS) (Macedo e col.1980, citado por PAIM 1994, p.37). Um dos objetivos do PPREPS era preparar em massa pessoal de nível médio (técnico e auxiliar) e elementar, para permitir a extensão de cobertura e a melhoria dos serviços (PAIM 1994, p.38).

Poucos anos depois, no início da década de 80, diante de uma franca crise da economia brasileira e da Previdência Social, foi proposto um projeto ambicioso, com respaldo político da VII CNS, denominado Programa Nacional de Serviços Básicos de Saúde - PREV-SAÚDE - encomendado a um grupo interministerial com apoio da 
OPAS e que tinha como objeto a universalização dos cuidados primários de saúde em todo o território nacional (MENDES 1993, p.34).

O PROJETO LARGA ESCALA foi apresentado nesse contexto, como proposta de capacitação de recursos humanos para promover a política de expansão dos serviços básicos de saúde. Elaborado em 1981, como resultado de um acordo entre os Ministérios da Saúde, Educação e Cultura, Previdência e Assistência Social e a OPAS, denominou-se PROGRAMA DE FORMAÇÃo DE PESSOAL DE NÍVEIS ELEMENTAR E MÉDIO PARA OS SERVIÇOS DE SAÚDE PROJETO LARGA ESCALA (SECRETARIA MUNICIPAL DA SAÚDE, 1993).

A formação em larga escala do pessoal de níveis médio e elementar, empregados nos serviços de saúde, surgia como uma proposta inovadora, que interrelacionava o ensino e o serviço de saúde através do seu próprio quadro de profissionais. Propunha-se a capacitar os trabalhadores, respeitando os seus esquemas de assimilação, buscando a reflexão através da prática do serviço, na busca de mudanças qualitativas, na relação entre os sujeitos aprendizes e a população usuária dos serviços.

A situação da formação de RH em saúde carregava no seu bojo outras demandas para as quais as novas práticas precisavam atentar, especialmente, a entrada em vigor em 25 de junho de 1986, da Lei n.7.498, que regulamentava o Exercício Profissional da Enfermagem. Passou-se a reconhecer como profissionais da área, apenas a auxiliar, a técnico e a enfermeira com o conseqüente descredenciamento das atendentes de enfermagem; estes, além, de terem as suas atividades profissionais bastante restringidas, deixavam de serem vistas como profissionais, tendo o prazo de dez anos para se qualificar. Assim, o PLE se configuraria também como uma modalidade de formação que viria ao encontro dos requisitos dessa lei.

Sabemos que várias foram as experiências de implantação do PLE nos municípios brasileiros, a partir de 1985 - particularmente nas unidades do Instituto Nacional de Previdência Social - INAMPS - no Rio de Janeiro, Goiás, Maranhão, Bahia, Pernambuco além das experiências dos Estados do Piauí e Minas Gerais (TORRES 1994). Há um número expressivo de referências avaliando positivamente a proposta, mas, também, publicações questionando a sua efetividade. 
Haddad e col (1990) citado por BÓGUS ( 1992, p.31), num artigo que retratou os principais trabalhos desenvolvidos na área de educação continuada na América Latina, fez referência ao PLE, como um processo dinâmico que auxiliaria na construção de um modelo assistencial de qualidade para a população, através da qualificação do trabalhador de saúde, resgatando suas habilidades e sua cidadania.

VIEIRA (1990), ao enfocar a formação do Atendente de Enfermagem como um desafio a ser superado na configuração do SUS, pôde avaliar, mesmo considerando a circunstância de ser uma modalidade de formação recente e de lentidão processual que o PLE vinha resultando em baixo impacto sobre o contingente de desqualificados na prestação de cuidados de saúde à população.

Para BÓGUS (1992), o PLE configurava-se como uma alternativa, praticamente isolada, de capacitação de pessoal de nível médio, que se instalou no país de uma forma mais sistemática.

PAIM (1994) cita estudos sobre o Larga Escala que reconhecem seus aspectos positivos, especialmente por tratar-se de uma iniciativa de caráter renovador, embora discuta, por outro lado, a existência de obstáculos de diversas ordens na sua implementação.

Na década de 90, o PLE foi marcado definitivamente pelo ideário da reforma sanitária contemplado na Constituição Brasileira que estabelece nos artigos 196, 198 e 200, respectivamente:

- A saúde é direito de todos e dever do Estado;

- As ações e serviços públicos de saúde constituem uma rede regionalizada e hierarquizada e constituem um sistema único, organizado de acordo com as diretrizes de descentralização, atendimento integral e participação da comunidade;

- a ordenação da formação de recursos humanos na área de saúde.

A adoção constitucional do ideário da reforma sanitária acabou por impor aos serviços de saúde, centros formadores, escolas técnicas e universidades, uma outra lógica para a formulação de políticas e estratégias de formação de RH, no sentido de contribuir para a implantação do próprio sistema e dos seus princípios e diretrizes.

Nesse sentido, estabeleceu-se um consenso técnico e político da necessidade de ampliação do espaço de influência do novo modo de organização dos serviços de 
saúde sobre o processo educacional dos agentes dessa prática (I CONFERÊNCIA NACIONAL DE RECURSOS HUMANOS 1986; SILVA 1993; TEIXEIRA 1993; SCHRAIBER 1993; PAIM 1994; MINISTÉRIO DA SAÚDE/RH/SUS s/d).

Em outras palavras, tratou-se de um consenso entre aqueles que desejavam implementar as estratégias de operacionalização do SUS, diante da visão de que a formação de RH no setor saúde pressupõe, por um lado, o reconhecimento de relações estreitas entre a política de saúde - que expressa determinadas formas de produção - e a política de formação dos agentes das práticas de saúde - materializada nas instituições de ensino (TEIXEIRA 1982 citado por PAIM 1994, p.7).

Por outro lado, pressupõe a necessidade de transcender a dimensão utilitarista dos recursos humanos, de forma que o trabalho desenvolvido pelo indivíduo não seja só o instrumento da sua participação, de sua cooperação no desenvolvimento dos serviços de saúde e da sociedade, mas também o instrumento do seu bem-estar social na busca da auto-realização como cidadão (SILVA 1993).

Apesar dos esforços de alguns projetos reformadores na preparação de trabalhadores de saúde e, de uma relativa autonomia das instituições de ensino, constata-se uma certa "timidez" nos resultados relativos às mudanças das práticas nos serviços de saúde. Há de se reconhecer que ainda nos dias de hoje, persiste com fôlego a orientação da matriz flexneriana, determinando a valorização da prática clínica, individualizante, conservadora, departamentalizada e dependente de interesses capitalistas médico - industriais (PAIM 1994, p.49-53).

Segundo Teixeira (1982) citado por (PAIM 1994, p.57) mudanças curriculares são indiscutivelmente necessárias frente à reorganização dos serviços porém, insuficientes para alterar o modo de produção dos seus agentes. No entanto, PAIM (1994) advoga a valorização de iniciativas que ampliem o debate sobre o desenvolvimento de RH e políticas de saúde, mesmo diante de conjunturas desfavoráveis.

Para o autor, um movimento cultural, em torno de um dado projeto de formação de RH em saúde, pode transformar-se em movimento político de maior vulto, alterando a correlação de forças institucionais. Como ele, acreditamos "que a estratégia com maior potencial de viabilizar mudanças na formação dos agentes é atuar sobre a estrutura das práticas de saúde, articulando, cada vez mais intensa e 
organicamente, o mundo do ensino ao mundo do trabalho" (PAIM 1994, p.56, o destaque é nosso).

A exemplo do que ocorreu em outras instituições de saúde, a SMS -SP dispunha de um quadro de pessoal no qual os trabalhadores de nível médio e elementar, correspondia a, aproximadamente, cinqüenta por cento dos servidores, sem acesso à educação geral e/ou qualificação profissional para o exercício das atividades no setor saúde (SECRETARIA MUNICIPAL DA SAÚDE, 1989; 1993).

A estratégia de formação desse contingente de pessoal, através da mediação de conhecimentos e da própria prática nos serviços, deveria atender aos princípios finalísticos e às diretrizes do novo modelo de atenção à saúde: a universalização, a equidade, a integralidade das ações, a descentralização e a participação popular para o exercício do controle social.

Partimos da premissa de que o PLE, nessa administração, representou uma estratégia de formação de pessoal a serviço da implementação dos princípios e das diretrizes políticas do Sistema Único de Saúde e, portanto, dos ideais do movimento da reforma sanitária.

Ao escolher esse projeto de formação, a gestão municipal estabeleceu como objetivo, provocar mudanças no comportamento dos trabalhadores de saúde, que lhes permitissem refletir sobre a organização dos serviços, a partir do reconhecimento da função social do trabalho em saúde e do respeito à população na perspectiva da qualidade da atenção e do compromisso social.

Originalmente, o desenvolvimento do curso buscava solidificar um conhecimento que não se restringisse aos aspectos técnicos, "estandardizados", da prática dos serviços. Almejava-se incorporar o contexto social e político das práticas sociais, através da construção coletiva do conhecimento alimentada pelos pontos de vista diversos e divergentes diante dos problemas de saúde a serem enfrentados (MINISTÉRIO DA SAÚDE, 1982).

Assim, as experiências do processo ensino-aprendizagem possibilitariam o conhecimento e a identificação de uma dada realidade social - mediante o reconhecimento da condição de cidadania do trabalhador - e o compromisso com a comunidade na construção de uma consciência sanitária (VIEIRA e SCUCATO 1988; TEIXEIRA 1989). 
Nesse sentido, segundo Schraiber (1991) citado por PAIM (1994, p.65) "para conceber a totalidade do real e compreender as múltiplas implicações da ação social, será preciso (...) que o sujeito tenha consciência da história e da sociabilidade da vida cotidiana. Não é só o domínio da consciência técnica, portanto, o que permite ao profissional e à população experimentar socialmente uma melhor expressão de si mesmo, mas sobretudo, a consciência política e social".

A pesquisa realizada por OLIVEIRA (1996) condiciona o sucesso das intervenções que objetivam a integração ensino-serviço a três fatores: o espaço político das ações, os recursos disponíveis, e a compreensão que os atores sociais têm das propostas educativas.

A divulgação de resultados de trabalhos, ao longo dos anos 90, cujo objeto de pesquisa foi o PLE, vem reforçar o nosso entendimento sobre a pertinência deste novo estudo:

a) AZEVEDO (1992) se propôs a investigar em que medida a metodologia de base problematizadora estava sendo implantada pela Escola de Auxiliar de Enfermagem do INAMPS - Rio de Janeiro, e para tanto dedicou-se a pesquisar sobre a contribuição da educação crítica para o desempenho de uma prática social transformadora. Segundo os resultados da pesquisadora, "a Escola estava implementando medidas capazes de efetuar mudanças significativas em prol do alcance dos objetivos do PLE embora, a prática docente apontasse, em parte, para aquela metodologia, necessitando ainda de aprimoramento no seu todo";

b) TORRES (1994) desenvolveu um estudo exploratório destinado a explicitar a dimensão "política" do projeto de qualificação dos trabalhadores de nível médio e sua influência na transformação das condições e relações de trabalho. Para a autora, a análise do processo de trabalho, que lhe pareceu um subsídio importante para facilitar a articulação das dimensões pedagógica e política, permitiu inferir a compreensão existente sobre a referida dimensão, ao relacionar "a competência técnica e o desenvolvimento da consciência política dos seus atores referenciada na prática profissional mais próxima à realidade";

c) OLIVEIRA (1996) desenvolveu um estudo voltado para a compreensão do processo de construção da modalidade de qualificação profissional do Projeto Larga Escala na formação do Auxiliar de Enfermagem, a partir do resgate das 
experiências vivenciadas pelos sujeitos educandos, numa região do município de São Paulo. Para essa autora, a pesquisa revelou "parte de um processo de formação em serviço que ainda não adquiriu a dimensão da transformação da prática mas, promoveu o consenso para a construção coletiva do conhecimento, participação e mobilização de trabalhadores de nível médio de enfermagem, renovando assim as práticas do trabalho e ampliando o seu sentido".

\subsection{Os objetivos e a finalidade do estudo}

Assim posto, nos propusemos a compreender a vinculação dos princípios e das diretrizes políticas do Sistema Único de Saúde aos conteúdos e estratégias dos cursos de formação do Auxiliar de Enfermagem através do Projeto Larga Escala. Chamou-nos a atenção a possibilidade de explicitar a relação ocorrida entre o espaço político das ações desenvolvidas pela administração municipal e a compreensão dos atores sociais sobre as propostas educativas referenciadas naquelas ações.

Estabelecemos então como objetivo:

- analisar a incorporação dos princípios e das diretrizes do SUS aos cursos de formação de Auxiliar de Enfermagem do Projeto Larga Escala da Secretaria Municipal de Saúde do Município de São Paulo, no período 1989 - 1992.

Por entender que a qualificação dos trabalhadores de saúde do nível médio, "passa necessariamente pela reelaboração dos paradigmas da formação profissional em função dos perfis ocupacionais dos serviços de saúde" (SANTANA 1990), acreditamos que os resultados desse trabalho possam fornecer subsídios para a análise e proposições de estratégias de reordenação da qualificação desses trabalhadores frente às sucessivas demandas do setor saúde. 


\section{POLÍticas PÚBLICAS DE SAÚDE: O CONTEXTO DA REFORMA SANITÁRIA E DO SISTEMA ÚNICO DE SAÚDE}

Propusemo-nos a realizar a aproximação da temática dos recursos humanos em saúde revendo o processo histórico que levou à proposição do SUS, para compreender o caráter das transformações que estavam em jogo e que, em maior ou menor escala, deveriam ser apropriadas pelo processo de qualificação dos trabalhadores de saúde. Sem querer esgotar aqui a compreensão do processo de formulação da política social pública de saúde no Brasil - já exaustiva e preciosamente estudada por autores consagrados do campo da saúde coletiva - não podemos, no entanto, nos furtar de percorrer a trajetória conceitual que culminou com sua formulação, especialmente no que se refere ao movimento da reforma sanitária, entendida como um sujeito político coletivo (COUTINHO, 2000).

Assim é que, recorremos inicialmente a COUTINHO (1989) para entender o “jogo" da formulação das políticas sociais públicas. Para esse autor, quando falamos de política, estamos nos referindo em grande medida à representação de interesses e, por conseguinte, à formulação de políticas que implementam ou bloqueiam tais interesses. Sob o capitalismo, a evolução da concepção marxista de Estado, mais propriamente vista a partir de Gramsci, vai afirmar o compromisso do Estado com o capital, mediado pela sociedade política, esteja ele nas mãos de industriais ou do setor financeiro. Porém, ao formular que no interior do Estado também está presente a sociedade civil, Gramsci reconhece a possibilidade de concorrerem interesses de outras classes, que atuarão de acordo com a correlação de forças entre as classes para a formulação das políticas.

A segunda metade do século XIX e o século XX se caracterizaram pela contínua expansão de direitos políticos e direitos sociais. A ampliação da cidadania levou, nesse período, a uma importante transformação na ordem liberal, manifestando-se na abertura do espaço político à representação de novos interesses. (COUTINHO 1989). Assim, é possível ver, como quer POLANTZAS (1990, p.148) que o "Estado não é pura e simplesmente uma relação, ou a condensação de uma 
relação; é a condensação material e específica de uma relação de forças entre classes e frações de classe".

Nesse movimento de constituição da sociedade civil, ocorre o estímulo à socialização política ou seja, "a ampliação do número de pessoas e de grupos empenhados organizadamente na defesa de seus interesses”. Com a socialização política, por sua vez, vai se formando uma complexa rede de organizações coletivas, de sujeitos políticos, "com um papel mais ou menos decisivo na correlação de forças que determina os equilíbrios de poder" (COUTINHO 2000, p. 26) e algumas concessões (FALEIROS 1991).

A sociedade civil passa então a ser estruturada por um poder de se organizar e influir nas decisões do Estado, através do controle de políticas sociais públicas que revertam em favor da sociedade como um todo e não somente de uma classe. A expressão políticas sociais refere-se àquelas medidas governamentais destinadas a garantir, em níveis mínimos, a reprodução da força de trabalho (DEMO 1988), significando o "esforço planejado de reduzir as desigualdades sociais". O que tem ocorrido sistematicamente é que o usufruto da cidadania tem sido diretamente proporcional aos recursos disponíveis aplicados na efetivação das políticas públicas, refletindo rígidas e gritantes desigualdades sociais e políticas (DEMO 1988).

Essas medidas são caracterizadas por programas, ações, benefícios, principalmente nas áreas básicas, de saúde, habitação, educação e trabalho, na verdade, setorizando, fragmentando e separando em diferentes esferas de competência governamental o que está indissoluvelmente integrado na vida, na realidade social (VALLA e STOTZ 1989).

A política de saúde faz parte da política social do Estado, é uma política setorial voltada para a preservação e/ou recuperação da saúde dos trabalhadores (VALLA e STOLTZ 1989). Segundo COHN (1991) a saúde, dentre as políticas setoriais, é a que se destaca na sociedade brasileira, devido a sua acentuada politização e forte presença de grupos de pressão.

Ao longo da década de 80, pudemos reconhecer, no cenário político brasileiro, diversos movimentos da sociedade civil na luta pela garantia de melhores condições de vida e justiça social, buscando o estabelecimento de direitos sociais 
através de políticas públicas, em busca de liberalização política e enfim, da democracia: "Um amplo debate perpassou a sociedade como um todo, no qual a possibilidade de reverter as enormes desigualdades sociais e a extrema extensão da pobreza se traduziu em propostas políticas que se centraram na redefinição de políticas sociais" (GERSCHMAN 1995, p.41).

Na luta pela transformação do sistema de saúde - que até aquele momento caracterizava-se pelo acesso desigual da população aos serviços de saúde, mediante a contribuição previdenciária - e, também das próprias condições de saúde dos brasileiros, foi se configurando um sujeito político coletivo (Coutinho 1984, citado por ESCOREL 1989) constituído inicialmente por intelectuais com atuação no campo da saúde, conhecido como Movimento Sanitário. Entre suas principais características podemos destacar a sua dimensão suprapartidária e sua organicidade. Tal característica pressupõe, de um lado, uma linguagem comum, cuja identidade se construiu através do código do pensamento médico social, e, de outro, um projeto de transformação das condiç̃̃es de saúde da população brasileira (o destaque é nosso) (Escorel 1987, citado por ESCOREL 1989, p.185).

Assim, o Movimento Sanitário configurou-se como um projeto contrahegemônico que englobou também a ética. "A ética remete-se à atitude do homem em relação ao mundo, no caso da saúde, à atitude de profissional de saúde para com seu "mundo": a profissão e a maneira como ela é exercida" (DÂMASO 1989, p. 94). Também é própria desse movimento, a influência determinada pelo meio acadêmico, mais particularmente, pela criação dos Departamentos de Medicina Preventiva nas Faculdades de Medicina, na década de 70, de onde se difundiu o pensamento crítico da saúde, trazendo para a ordem do dia a discussão sobre os determinantes sociais do processo saúde-doença. "É nesse limiar crítico que se constituirá uma teoria histórico-estrutural da doença, que fundará um novo objeto de estudos: o da saúde coletiva. É como se assistíssemos na realidade, a um deslocamento desde um paradigma clínico em direção a um paradigma histórico-estrutural" (DÂMASO 1989, p. 81).

De acordo com Escorel (1988), citada por COUTINHO (1989, p. 68), o Movimento Sanitário provocou uma reviravolta na saúde, transformando os 
conceitos, incluindo a política na análise e na prática da saúde (o destaque é nosso)." O movimento sanitário concentrou sua ação estratégica na ocupação do aparelho administrativo executivo do Estado e a partir daí, realizou tentativas de transformações nas relações entre Estado e sociedade através da política de saúde". A institucionalização do movimento sanitário deu origem à denominada Reforma Sanitária (LUCCHESI 1989, p.176).

\footnotetext{
O conceito de Reforma Sanitária refere-se a um processo de transformação da norma legal e do aparelho institucional que regulamenta e se responsabiliza pela proteção à saúde dos cidadãos que corresponde a um efetivo deslocamento do poder político em direção às camadas populares, cuja expressão material concretiza-se na busca do direito universal à saúde e na criação de um Sistema Único de Serviços sob a égide do Estado (TEIXEIRA 1989, p.194).
}

O "direito à saúde defendido na Reforma Sanitária" trouxe intrinsecamente o apoio, a participação e a pressão dos setores populares. Isso passou a significar que “o direito social de ter garantida a condição de saúde de uma população supõe o próprio movimento dessa população em conseguir o reconhecimento e efetivação desse direito" (Sposati e Lobo 1992, citado por CAPISTRANO e col. 1992, p.22).

Esse processo teve como princípio orientador a ampliação social e a constituição da cidadania na construção da democracia (GERSCHMAN, 1995).

O processo da reforma sanitária impulsionou a realização da VIII Conferência Nacional de Saúde, convocada pelo Ministério da Saúde e realizada em 1986. Ao contrário do caráter tecnicista das conferências anteriores, os debates que se travaram no decorrer da VIII CNS trouxeram à tona a discussão de que as políticas deveriam ser encaminhadas por diferentes setores da sociedade, marcando contundentemente a história da saúde no Brasil, uma vez que definiu um Programa para a Reforma Sanitária. Além disso, a Conferência representou um avanço técnico e um pacto político, ao propor a criação do Sistema Único de Saúde - SUS, tendo entre seus princípios e diretrizes: a descentralização, a universalidade, a equidade, a integralidade das ações e a participação social.

O processo de mobilização da sociedade teve continuidade nos trabalhos de elaboração da nova Constituição Brasileira, a denominada "Constituição Cidadã" na 
qual a Comissão Nacional da Reforma Sanitária e a Plenária Nacional de Entidades de Saúde elaboraram um capítulo inédito que versa sobre a saúde." Os principais pontos aprovados na Carta Magna de 1988 foram: o direito universal à saúde; a saúde como um dever do Estado; a constituição do Sistema Único de Saúde - SUS" (BERTOLOZZI e GRECO 1996, p.392).

\begin{abstract}
Esta nova formulação para uma política de saúde incorporou o conceito mais abrangente de saúde, entendendo-o como resultante de fatores relativos ao meio físico (condições geográficas, disponibilidade de água, habitação), ao meio sócio-econômico e cultural (ocupação, renda, educação), aos fatores biológicos (idade, sexo, herança genética) e da oportunidade de acesso aos serviços que visem a promoção, proteção e recuperação da saúde. Trata-se então, de uma política pública, de responsabilidade do Governo, onde são necessárias ações em vários setores afim de se garantir os princípios doutrinários do sistema: universalidade, livre acesso de todos os cidadãos brasileiros; equidade, garantia das ações e serviços em todos os níveis de acordo com as necessidades prestação de assistência integral ao indivíduo a partir da visão deste e integralidade, como sendo um complexo biopsico-social (ALMEIDA 1995, p.33).
\end{abstract}

Além da criação do Sistema Único de Saúde e da estipulação de suas diretrizes, era preciso regulamentá-lo e torná-lo uma realidade. Para isso, foi necessária uma série de leis complementares, como a 8.080, de 12 de setembro de 1990, e a 8.142, de 28 de dezembro de 1990, além das Normas Operacionais Básicas do Ministério da Saúde - NOB (BARRETO JUNIOR, 1999).

Apesar de toda a mobilização da sociedade civil organizada ao longo da última década, que marchou rumo à democratização do país e, no caso do setor saúde, resultou na formulação do SUS, vivemos, ao final dessa década, uma crise social jamais vista. $\mathrm{O}$ continente latino-americano sofreu os reflexos de uma crise mundial, gerada no interior do sistema capitalista, que permitiu a ascensão de uma força político - ideológica neoliberal - postulante do mercado como o melhor mecanismo tanto para o desenvolvimento da economia quanto para a satisfação individual - portanto, a intervenção do Estado na economia precisaria ser minimizada e os direitos sociais eliminados (LAURELL 1999).

A operacionalização do SUS tem enfrentado uma política hegemônica, de influência internacional, caracterizada por uma redistribuição regressiva da riqueza, levando a um processo maciço de empobrecimento populacional, pela transferência das responsabilidades sociais do Estado aos investimentos privados, pela destruição 
das instituições públicas mediante a privatização do financiamento e da produção dos serviços e ainda, pelos cortes dos gastos e pela redução dos benefícios sociais. "Portanto, o neoliberalismo opõe-se radicalmente à universalidade, igualdade e gratuidade dos serviços sociais" (LAURELL 1999, p.163).

Nessas circunstâncias, defender a operacionalização do SUS e os princípios doutrinários da Reforma Sanitária Brasileira, consiste em não abandonar o espaço político que a sociedade civil ocupou na correlação de forças que se estabeleceu a partir da década de 80 , posicionando-se contra o projeto neoliberal instalado no país. Significa incrementar um movimento nacional de resistência comprometido com a concretização da saúde como direito social, o que, aliás, é reconhecido no artigo $6^{\circ}$ da Constituição Federal de 1988. 


\subsection{Princípios e diretrizes políticas do SUS}

Como já descrevemos em capítulo anterior, duas são as Leis Orgânicas da Saúde - LOS - que referem-se à implementação da política de saúde no Brasil. Neste capítulo, far-se-á uma incursão mais pormenorizada por alguns princípios e diretrizes do SUS, tomados a priori como categorias de análise, derivadas dos marcos teóricos da reforma sanitária que orientam esta pesquisa: descentralização, universalidade, equidade, integralidade e participação popular.

Consideramos necessário esclarecer que a pesquisa aqui realizada a respeito dos princípios e diretrizes do SUS respaldou-se na publicação de Guido I Carvalho e Lenir Santos, 1992. Para esses autores, o Sistema Único de Saúde obedece aos seguintes princípios: universalidade, integralidade da assistência, igualdade de assistência, participação da comunidade, descentralização políticoadministrativa com direção única em cada esfera de governo (os grifos são nossos) entre outros.

As diretrizes que advém desses princípios determinam como o Sistema Único de Saúde deva estar organizado, ou seja, de acordo com a descentralização, o atendimento integral; e a participação da comunidade (os grifos são nossos).

Em consonância, o ABC DO SUS: doutrinas e princípios, Ministério da Saúde, 1990, embora utilizando-se de uma terminologia diferente, interpreta que a construção do SUS se norteia pelos princípios doutrinários da universalidade, equidade e integralidade, regida pelos princípios organizativos [ou diretrizes] da regionalização e hierarquização, resolubilidade, descentralização, participação dos cidadãos e prevendo a complementariedade do setor privado, filantrópico e conveniado.

\subsubsection{Descentralização}

Até a aprovação do SUS, o sistema de saúde existente no Brasil era considerado centralizado tendo as decisões político-administrativas concentradas nos âmbitos federal e estadual (SILVA 1996, p.83). A descentralização vai, 
historicamente, se constituindo como uma preocupação do setor saúde - mais propriamente daqueles que pleiteavam a mudança do sistema de saúde brasileiro desde o início da década de 70, com as experiências localizadas e desenvolvidas por técnicos e governos de oposição (ELIAS 1996) - para ser finalmente promulgada, como uma das diretrizes do SUS, no capítulo II da LOS de 1990:

\section{$I X$ - descentralização político-administrativa, com}

\section{direção única em cada esfera de governo:}

\section{a) ênfase na descentralização dos serviços para os} municípios;

\section{b) regionalização e hierarquização da rede de serviços}

de saúde;( os destaques são nossos).

O desenvolvimento dessa diretriz na lei teve suas bases na Constituição de 1988 que preconiza (art. 18) a autonomia dos diversos níveis de governo da federação, atribuindo aos municípios a competência de (art. 30, VII)

"prestar, com a cooperação técnica e financeira da União e do Estado, serviços de atendimento à saúde da população" citado por SILVA (1996, p.82).

Em termos gerais, descentralização poderia ser conceituada, com ligeiras diferenças, de autor para autor, como:

a transferência de poder do nível nacional para instâncias subnacionais, para planejar, gerir, executar e tomar decisões. No âmbito das políticas públicas, a descentralização significa um processo de reestruração interna ao aparelho do Estado, que perpassa as várias esferas de governo, envolvendo aspectos políticos, administrativos, técnicos e financeiros (SILVA 1996, p. 81).

ou,

uma questão de natureza essencialmente política, que implica redistribuição de poder decisório, prestando-se, na ação política, à apropriação de diferentes segmentos do espectro ideológico, frequentemente associada a um projeto político mais amplo. No caso das políticas sociais e das de saúde em particular, o processo de descentralização desdobra-se em três dimensões independentes, ainda que sempre articuladas entre si: a política, envolvendo os aspectos referentes à autonomia para formular e proceder as escolhas desta natureza; a financeira, versando sobre a liberdade para alocação de recursos e os critérios de aplicação; e a administrativa, envolvendo a liberdade para 
adoção dos princípios e diretrizes voltados para organização da máquina administrativa (ELIAS 1996, p. 100).

Assim, esses e outros autores que discutem a política de saúde no Brasil têm feito diversas incursões para conceituar a descentralização aplicada a esse setor. Como vimos, o tema é tratado por ELIAS (1996) numa complexa e ampla discussão sobre o caráter diferenciado que a descentralização pode assumir, a depender da abordagem teórica que a orienta: tratada pela ótica do Estado, estando em jogo sua reestruturação, a descentralização pode adquirir um caráter transformador ou conservador.

A descentralização, concebida com um caráter de transformação do Estado envolve uma série de objetivos a serem atingidos no decorrer do seu processo de implementação: o controle social, a participação, a equidade e a democracia. "Tal concepção implica na transferência de poder decisório associado aos recursos mínimos necessários para garantir o seu exercício concreto” (p. 71), o que por sua vez implica a implementação de mecanismos para a democratização das decisões.

O caráter conservador da descentralização é evidenciado por seu objetivo racionalizador, para garantir a manutenção da relação dominante entre as classes, reproduzindo o capital nos seus momentos de produção e de consumo.

O conceito de descentralização contido na proposta do SUS foi estruturado a partir das metas da Reforma Sanitária, no que se refere à implementação de um sistema que imprimisse autonomia ao nível local.

Toma-se aqui por pressuposto que a abordagem que orientou a reforma sanitária brasileira nutriu-se dos conceitos relacionados à necessidade de transformar o Estado. Assume-se portanto que esse movimento estava historicamente relacionado a:

\footnotetext{
um processo de transformação da norma legal e do aparelho institucional que regulamenta e se responsabiliza pela proteção à saúde dos cidadãos e corresponde a um efetivo deslocamento do poder político em direção às camadas populares, cuja expressão material se concretiza na busca do direito universal à saúde e na criação de um sistema único de serviços sob a égide do Estado (TEIXEIRA 1989, p.39).
}

A efetivação da descentralização, não obstante constar na lei e orientar-se pela direção transformadora dada pela reforma sanitária, depende, em última 
instância, da distribuição de competências para o município desde a sua administração até a sua execução.

\begin{abstract}
Os meios para atingir este objetivo [fortalecer a esfera local] referem-se à transferência de algum tipo de poder decisório, ou de ação estatal, ao poder local, o que demanda deste capacitação de várias ordens técnica, financeira, administrativa, gerencial, entre outras. Desta ótica, a descentralização exige pré-requisitos do nível local para sua efetivação; e mais, mesmo na inexistência desta, a esfera central encontra-se comprometida com a local, no sentido do provimento do auxílio necessário para a obtenção desses requisitos (ELIAS 1996, p. 81).
\end{abstract}

\title{
2.1.2. Universalidade
}

A Constituição Brasileira refere-se à universalidade como sendo uma condição inerente ao direito à saúde:

Art.196 - "A saúde é direito de todos e dever do Estado, garantido mediante políticas sociais e econômicas que visem à redução do risco de doenças e de outros agravos e ao acesso universal igualitário às ações e serviços para sua promoção, proteção e recuperação" (o destaque é nosso).

No dispositivo da Lei 8080/90 cap.II essa diretriz é tratada da seguinte forma:

“Art. $7^{\circ}$ - As ações e serviços públicos de saúde e os serviços privados contratados ou conveniados que integram o Sistema Único de Saúde (SUS) são desenvolvidos de acordo com as diretrizes previstas no art. 198 da Constituição Federal, obedecendo ainda aos seguintes princípios:

I - universalidade de acesso aos serviços de saúde em todos os níveis de assistência"' (o destaque é nosso).

O reconhecimento de que as políticas públicas de saúde estiveram, historicamente, dependentes dos interesses econômicos e, excluíram a maioria da população do acesso à saúde, é fundamental para dimensionar a amplitude das reivindicações do movimento sanitário e, em particular, a diretriz da universalidade. A sua incorporação no texto constitucional tem por finalidade estender a cobertura da 
atenção à saúde a todos os cidadãos brasileiros, de forma justa, desatrelada de qualquer condição.

Quando recorremos aos dados históricos que contextualizam a política econômica brasileira no início do processo de industrialização, constatamos que as ações e serviços de saúde desenvolvidos na época, limitavam-se à parcela dos trabalhadores beneficiários da previdência social, criada em 1923 e vinculados às Caixas de Aposentadoria e Pensão e posteriormente, aos Institutos de Aposentadorias e Pensões. "Cabe ressaltar que desde o início, o sistema previdenciário não foi baseado no conceito do direito à previdência social, inerente à cidadania, mas considerado um direito contratual, baseado em contribuições ao longo do tempo" (Possas 1981 citada por BERTOLOZZI e GRECO 1996, p.383).

Essa condição permaneceu inalterada durante décadas ao longo da expansão capitalista do desenvolvimento industrial e do denominado milagre brasileiro. A assistência à saúde esteve destinada, privilegiadamente, aos previdenciários e, a partir de 1971, foi estendida aos trabalhadores rurais e depois aos empregados domésticos e aos autônomos; continuou sendo vista porém, como um direito que se adquire pelo trabalho.

Ressaltamos a visão tradicional nas políticas de saúde brasileiras, que relacionava a aquisição de direito à atenção à saúde ao exercício do trabalho, sobretudo o trabalho urbano e formal. Essa condição poderia tornar os serviços médicos inacessíveis à maior parte da população brasileira isto é, às crianças, às donas de casa, aos jovens não empregados, aos velhos sem aposentadoria, aos subempregados da economia informal, aos desempregados (LUZ 1994).

A essa parcela significativa da população, sem direito ao benefício da previdência, foi implantado em 1974, o Plano de Pronta Ação - PPA -, destinado à prestação de assistência às urgências. Novamente, a Previdência Social foi a responsável pelo credenciamento de inúmeros prestadores de assistência nos denominados "pronto atendimento" e "pronto socorros", mediante distintas formas de pagamento (MENDES 1993).

Alguns outros mecanismos foram criados e regulamentados, permitindo a setores da economia oferecer serviços assistenciais a segmentos da população, 
mediante o financiamento do setor público. Estabeleceu-se de forma hegemônica o denominado modelo assistencial médico privatista (MENDES 1993).

A partir da década de 80, com a crise da economia brasileira, da Previdência Social, e no contexto da redemocratização do país, houve uma verdadeira eclosão de movimentos sociais organizados para resgatar direitos sociais, na busca por melhores condições de vida mediante a melhor distribuição da riqueza e de serviços, tomando vulto na área de saúde, como já vimos, o movimento sanitário (MENDES 1993; LUZ 1994).

No cenário de saúde brasileiro surgem propostas respaldadas por organismos internacionais, baseadas na Conferência Internacional de Cuidados Primários de Saúde, de Alma-Ata em 1978, comprometidas com o desenvolvimento de assistência de baixo custo às populações marginais e com a extensão da cobertura assistencial.

Algumas foram as propostas reformadoras do sistema de saúde na década de 80. Primeiramente, propôs-se o denominado Programa Nacional de Serviços Básicos de Saúde - PREV-SAÚDE - que tinha como objetivo a universalização dos cuidados primários em saúde em todo o território nacional que não conseguiu ser implantado.

Em seguida, tentou-se uma transformação com a proposição de um Conselho Nacional de Administração de Saúde Previdenciária - CONASP - comprometido com a redução dos custos da assistência médica e com a priorização das ações primárias com ênfase na assistência ambulatorial.

A partir de 1982, foi o Plano de Ações Integradas de Saúde - AIS -que representou a implementação de mudanças na relação entre o setor público/privado, passando a privilegiar o financiamento do setor público, e propondo alterar o modelo médico assistencial, dando prioridade à assistência ambulatorial, com o propósito de permitir a extensão da cobertura e a melhoria da qualidade dos serviços. As AIS foram substituídas pelo Sistema Unificado e Descentralizado de Saúde - SUDS a partir de 1987 (MENDES 1993; LUZ 1994; BERTOLOZZI e GRECO 1996).

Essas mudanças já se efetivavam no interior da reforma sanitária e de acordo com a capacidade de pressão dos grupos que participavam culminando na VIII CNS, em 1986. Nesse processo, as reivindicações tinham como sustentação teórica um conceito ampliado de saúde, definida como um direito do cidadão e, consequentemente, um dever do Estado e a proposta de instituição de um SUS que 
guarde entre outros o princípio da universalidade da atenção à saúde (MENDES 1993).

“Aqui, num terreno eminentemente político, propugna-se a transição de uma cidadania regulada, base das políticas de saúde compensatórias, para uma cidadania plena que reconheça o direito igual de todos às ações de saúde” (Santos 1987, citado por MENDES 1993, p.43).

“A universalização é a expressão liberal na relação Estado/Sociedade em que ““Todos os cidadãos têm direito à Saúde”" (....) (HEIMANN e col. 1992, p.35).

Assim posto, podemos reconhecer que a incorporação dessa proposição na Constituição Federal Brasileira, (Cap.II), "pode ser considerada com uma das conquistas mais notáveis da história das políticas de saúde” (LUZ 1994).

\begin{abstract}
A ampliação do acesso à atenção à saúde, provendo a um maior número de pessoas um leque maior e mais diversificado de ações e serviços de saúde, tem sido implementada através de uma série de mecanismos legais, institucionais e organizacionais, que buscam unificar e descentralizar essa atenção, construindo o Sistema Único de Saúde (GIOVANELLA e FLEURY 1996, p.177).
\end{abstract}

\title{
2.1.3. Equidade
}

A Constituição Federal do Brasil no seu artigo 196, e a Lei Orgânica da Saúde no seu inciso $1^{\circ}$, definem "a saúde como direito do cidadão e dever do Estado, garantido mediante políticas sociais e econômicas que visem à redução do risco de doenças e de agravos e do acesso universal e igualitário (o destaque é nosso) às ações e serviços para sua promoção, proteção e recuperação”.

Para compreendermos o que se objetiva no dispositivo da Lei com relação ao acesso igualitário, é necessário, uma vez mais, recorrermos ao ideário do Movimento Sanitário Brasileiro e lá resgatar as discussões voltadas para as condições de assistência à saúde da população. Tal ideário compreendia a necessidade de reduzir as desigualdades na distribuição dos recursos públicos e da saúde em particular, reconhecendo-a também como um direito universal. 
A igualdade pretendida somente seria atingida mediante $\mathrm{o}$ desenvolvimento de políticas que buscassem a justiça social (PELICIONI 1989; TEIXEIRA 1989).

Assim, KADT e TASCA (1993, p.13) ao referir-se à equidade, a colocam no âmbito da justiça social, posto que se refere a questões que envolvem juízos de valor freqüentemente relacionados com a distribuição de renda, de riquezas, e de outros benefícios, assim como opções políticas quase sempre associadas à alocação de recursos.

GERSCHMAN (1995) compartilha dessa idéia ao afirmar que a questão da equidade é um componente principal da democracia. "A equidade é embutida na idéia da cidadania, não como princípio, mas como o resultado das lutas sociais que transformaram a idéia de cidadania na obtenção de direitos concretos pela população" (p.32) "Assim, a equidade, enquanto resultado, nada mais é do que a maneira pela qual as modernas democracias sociais traduziram politicamente, sob o capitalismo, as desigualdades sociais em distribuição mais eqüitativa da riqueza e maior bem-estar social" (p.33).

No início dos anos 90, a maioria dos governos incorporou a equidade em suas diretrizes políticas para a saúde. A plataforma da OMS para o ano 2000 Saúde para Todos - apontava claramente o objetivo da equidade na assistência à saúde. Muitos planos de ação elaborados por autoridades do setor saúde enfocavam iniquidade e desigualdades, enfatizando muitas vezes profundas disparidades no âmbito da saúde em países diferentes ou no interior de um mesmo país. Frente a isto, "tanto ministros de saúde quanto organizações internacionais recomendaram que a política de saúde deveria estar voltada para ações cujas metas seriam atingir 'os menos privilegiados'(o destaque é nosso)" (KADT e TASCA 1993, p.11-2).

COHN e col. (1991, p.21-2) reconhecem que as políticas de saúde implementadas no país cristalizaram um acesso extremamente desigual da população aos serviços de saúde. Se por um lado, elas instituíram a concepção do direito, por outro, o vincularam à contribuição previdenciária e/ou de seguros de saúde privados. Reverter esse processo, isto é, perseguir a equidade, significa não "apenas eliminar privilégios de grupos e pessoas, mas também contemplar a discriminação positiva, a fim de garantir 'mais' direitos a quem tiver 'mais' necessidades, (o destaque é 
nosso), dada a própria especificidade da saúde, em que doenças iguais não significam doentes com necessidades iguais" (Vianna 1989, citado por COHN e col. 1991).

A equidade tornou-se uma finalidade comum aos programas da política social, embora muitas vezes tenha sofrido diferentes interpretações. No plano internacional, a equidade vem sendo apontada como uma meta a ser perseguida pelo setor saúde. Assim, CHIESA (1999, p. 21) destaca que em 1988, na Conferência realizada em Adelaide, Austrália, as discussões centraram-se no tema das Políticas Públicas Saudáveis, com enfoque para o conceito de equidade como uma meta para a superação das desigualdades decorrentes da inserção social desigual.

Da mesma forma, na Conferência Internacional de Promoção à Saúde, realizada em Santa Fé de Bogotá, em 1992, a importância da equidade é novamente resgatada propondo-se "transformar as relações excludentes, conciliando interesses econômicos e propósitos sociais de bem-estar social” (CHIESA 1999, p.21).

\footnotetext{
Hipoteticamente, há três situações possíveis tanto para a desigualdade como para a iniquidade, que assim são concebidas:

- desigualdade com iniquidade, é a situação mais comum em áreas urbanas dos países menos desenvolvidos, cujos serviços públicos são mais disponíveis, acessíveis e efetivos para grupos mais privilegiados;

- iniquidade sem desigualdade aparente, freqüente nos países mais desenvolvidos, onde há ampla distribuição de serviços de infra-estrutura de qualidade relativamente boa, mas que efetivamente não têm capacidade de atingir os grupos mais desfavorecidos.

- desigualdade aparente sem iniquidade, onde os recursos são alocados de modo desigual, de modo a aliviar a situação dos que se encontram em piores condições de saúde (KADT e TASCA 1993, p.14).
}

Para CHIESA (1999), “o planejamento de ações centradas no princípio da equidade deve ampliar os poderes dos indivíduos e grupos para atuar nos processos geradores da saúde-doença". O desafio da Promoção à Saúde, "está centrado na transformação das relações excludentes, através de estratégias de trabalho intersetorial que conciliem interesses para ampliar o desenvolvimento e a garantia do bem estar social, como condição indispensável para a melhor qualidade de vida" (p.162). "O fortalecimento da ação intersetorial esbarra em condições políticas propícias ao desempenho do papel das instituições promotoras de políticas públicas cujo objetivo é, a promoção da equidade e a integralidade no atendimento ao cidadão "(p.189). 
Iniquidade na saúde implica de modo evidente uma falta de satisfação das necessidades de saúde, possivelmente em decorrência de uma distribuição de serviços de saúde que não leva em consideração a distribuição heterogênea das necessidades da população. Portanto, conhecer a distribuição das necessidades de saúde é crucial para a implementação de uma política de saúde equiitativa. Ela leva em conta o diferencial de necessidade na alocação de recursos financeiros e humanos para serviços e atividades que pretendam dar uma resposta a tal necessidade. "Adotar a equidade requer concentrar-se nos mais necessitados, (o destaque é nosso) mas isso pode ser muito oneroso" (KADT e TASCA 1993, p.19).

\subsubsection{Integralidade}

Para discutirmos a diretriz da Integralidade, recorremos inicialmente a um debate realizado em 1986, promovido pela Associação Paulista de Saúde Pública, denominado A propósito da reforma sanitária, onde a integralidade, entre outras diretrizes, foi citada como síntese de uma proposta de texto constitucional, da seguinte forma:

“integralidade das ações de saúde,(o destaque é nosso) isto é, ausência de dicotomia ou de discriminação institucional entre as ações de promoção, proteção e recuperação da saúde, nos diferentes níveis de atenção”.

A Constituição Federal no artigo 198 determina que "As ações e serviços públicos de saúde integram uma rede e constituem um sistema único organizado de acordo com as seguintes diretrizes:

II - atendimento integral, (o destaque é nosso) com prioridade para as atividades preventivas, sem prejuízo dos serviços assistenciais”.

A Lei $8080 / 90$ em seu art. $7^{\circ}$, destaca entre outros princípios o da “integralidade da assistência, entendida como um conjunto articulado das ações e serviços preventivos e curativos, individuais e coletivos, exigidos para cada caso em todos os níveis de complexidade do sistema” (o destaque é nosso). 
CARVALHO (1991), ao estudar a integralidade por referência aos modelos assistenciais de unidades básicas de saúde, discorre a respeito do entendimento de assistência integral recorrendo, inicialmente, à expressão de Gentile de Melo (1980), que articula uma compreensão do homem em suas dimensões - biológica, psíquica e social - à concretização da prática dos serviços de saúde, através da prestação de ações integradas de saúde. Assim, por trás do conceito de integralidade, existe um entendimento da complexidade do ser humano e de como deve ser abordada a sua saúde (CARVALHO 1991, p.35).

Raggio (1992), citado por SILVA JUNIOR (1996, p.90) apresenta uma conceituação da integralidade das ações de saúde a partir das resoluções da VIII Conferência Nacional de Saúde. Naquele momento, buscou-se uma correlação dos problemas de saúde cuja definição compreende uma totalidade biopsico-social de cada indivíduo e de cada grupo social, ao seu enfrentamento que requer também uma totalidade que supere as dicotomias preventivo-curativo, clínico-epidemiológico e individual-coletivo.

"Entende-se por ações integrais de saúde o conjunto articulado de medidas de promoção, proteção, recuperação e reabilitação prestadas por uma equipe de saúde" (Ministério da Saúde/Ministério da Previdência e Assistência Social - Programa Nacional de Serviços Básicos de Saúde - PREV-SAÚDE citado por CARVALHO 1991, p.34-5).

Um documento da Secretaria de Organização das Unidades do Sistema Unificado de Saúde - SESUS - SG/MS de 1990 citado por CARVALHO (1991, p.35) refere o princípio da integralidade como um dos mais importantes do modelo assistencial, pois ele preconiza que se deve "assegurar aos indivíduos o direito à atenção à saúde, dos níveis mais simples aos mais complexos, da atenção curativa à preventiva, bem como a compreensão do indivíduo em sua totalidade e dos indivíduos/coletividades em suas singularidades".

Na opinião de CARVALHO (1991), a viabilização da atenção integral só será possível se houver uma equipe multiprofissional em cada unidade que atue a partir 
de uma abordagem interdisciplinar ${ }^{3}$ do que seja a atenção em saúde ao indivíduo e à população na realidade em que se insere.

Além disso, a assistência à saúde deve ser vista mais amplamente com sendo atenção à saúde, pois esta expressão "se coaduna mais com o conceito e a proposta de trabalho em saúde que se quer desenvolver, onde a assistência individual tradicional, através da consulta médica e/ou de enfermagem, é apenas uma modalidade de atenção” UCBS (1989) citado por CARVALHO (1991, p.38).

Atenção integral pode ser conceituada tanto para o indivíduo, quanto para o coletivo. Assim, atenção integral a uma pessoa "significa também prestar ações curativas, preventivas e sanitárias integradamente, mediante a atuação de uma equipe interdisciplinar, eliminando o atendimento por especialidades que se justapõem e garantindo a referência e contra-referência a níveis mais complexos “(CARVALHO 1991, p. 38).

No nível coletivo, "significa atender a toda uma população, cobrindo todos os grupos etários, entendendo e incorporando à prática uma concepção ampla de saúde, coerente com formas não tradicionais de atuação e relacionamento equipecomunidade, possibilitando à população a oportunidade de compreender os determinantes do seu processo de saúde/doença, e contribuindo para o desenvolvimento de sua consciência sanitária “(CARVALHO 1991, p. 39).

CARVALHO (1991) apresenta e discute uma concepção de integralidade que se contrapõe à divisão crescente do trabalho e portanto, à tendência à alienação, a departamentalização, e cuja operacionalização é um desafio.

Segundo esse pesquisador, “do ponto de vista estratégico, adotar a integralidade significa atuar visando a ampliação da cobertura, melhoria de qualidade e eficácia das ações, (....) ao mesmo tempo que se introduzem mudanças nos objetivos, métodos e práticas de prestação de serviços. Tal estratégia visa transformar o modelo assistencial privatista em um modelo integrado e racionalizado, em que as ações de assistência individual se ampliem para a assistência à família, aos grupos populacionais e às ações sobre o meio ambiente. A conseqüência deste processo será a construção de um modelo de atenção integral à saúde que materialize uma nova

\footnotetext{
${ }^{3}$ Japiassú (1976) citado por CARVALHO (1991, p.36) afirma que a "interdisciplinaridade caracteriza-se pela intensidade das trocas entre os especialistas e pelo grau de integração real das disciplinas”.
} 
concepção de saúde-doença como fenômeno biológico e social" (Plano diretor da cidade do Rio de Janeiro 1991, p.38 citado por CARVALHO 1991, p.67).

MENDES (1993, p.143-9), ao abordar a dimensão técnica do processo de distritalização da saúde, apresenta a integralidade como um dos princípios organizativo-assistenciais cuja incorporação à prática sanitária manifesta-se em duas dimensões:

“a) numa integração, definida por um problema a enfrentar através de um conjunto de operações articulados pela prática da vigilância à saúde;

b) numa integração, dentro de cada unidade de saúde, entre as práticas sanitárias de atenção à demanda e da vigilância à saúde“.

É entendimento desse autor, que a "integralidade exige, exatamente, uma intervenção integradora, no seu âmbito tecnológico, sobre indivíduos, famílias, ambientes coletivos, grupos sociais e meio ambiente".

SILVA JÚNIOR (1996), ao pesquisar as diversas estratégias de operacionalização do SUS, apresenta três experiências comprometidas com o princípio da integralidade:

- a atuação no Distrito de Saúde de Pau da Lima - BA, onde o enfrentamento do problema das doenças diarreica e o cólera teve como sustentação a discussão teórica de MENDES e o princípio da integralidade no distrito sanitário;

-. o Projeto Nascer em Curitiba vale a vida, organizado para enfrentar a morbidade e a mortalidade infantis a partir de critérios de classificação por risco através das Declarações de Nascidos Vivos encaminhadas às Regionais de Saúde;

- e a proposta Em Defesa da Vida, desenvolvida pela Secretaria Municipal de Saúde de Campinas, que se propõe a incorporação de elementos da psicanálise e da análise institucional na atuação da equipe de saúde para ampliar a capacidade de perceber a demanda e oferecer serviços mais adequados.

\subsubsection{Participação popular}


COÊLHO (1999), ao analisar a Constituição Federal de 1988, afirma que "a referida constituição inaugura uma nova ordem normativa, qual seja, o Estado de Direito, cujo ponto inicial encontra-se no reconhecimento da soberania popular como a única fonte de poder legítimo":

“Todo poder emana do povo, que o exerce por meio de representantes eleitos, ou diretamente, nos termos desta constituição“. (Constituição Federal, artigo $1^{\text {o }}$, parágrafo único citado por COÊLHO 1999, p. 92).

Na Seção II Da Saúde - Artigo 198, inciso III, a participação da comunidade(o grifo é nosso) é uma das diretrizes que norteará a organização do Sistema Único de Saúde.

A incorporação dessa diretriz ao texto constitucional não é condição suficiente para garantir a saúde da população mas representa uma característica dos processos de implantação de uma reforma.

Voltando ao contexto do final dos anos 70 e começo dos anos 80 - marco na política brasileira em torno do processo de democratização do país - é possível perceber o amplo espectro de forças sociais (sindicatos, entidades profissionais, associações de bairro, movimentos contra a carestia, movimentos de saúde, habitação) ${ }^{4}$ envolvidos na luta política para concretizar as eleições diretas para presidente da República.

Nesse contexto, originou-se o movimento social em saúde como aquela parte específica do movimento social cuja articulação e reivindicações são relacionadas à questão saúde. Para GERSCHMAN, 1995, o movimento social em saúde foi composto pelo Movimento Popular em Saúde e pelo Movimento Médico 5 .

BÓGUS (1997, p.6) cita o Movimento de Saúde da Zona Leste como o mais importante movimento popular de saúde a partir do início da década de 70, e que inicialmente tinha uma atuação voltada para a reivindicação de uma infra-estrutura

\footnotetext{
${ }^{4}$ Estamos utilizando aqui o conceito de "movimento social" de GERSCHMAN (1995, p.65) como o conjunto destas novas formas de associação, independente de qual fosse o tipo de reivindicação e de qual tipo de articulação institucional tenham conseguido alcançar.

5 Da mesma forma, utilizamos o conceito de "Movimentos Populares em Saúde" (GERSCHMAN 1995, p . 66) como uma "denominação genérica de todas as formas associativas que agrupam os moradores de bairros e favelas em torno de reivindicações relacionadas à saúde da população, fossem elas referidas a atendimento médico, saneamento, condições de saúde da população, prevenção à saúde, ou, em estágio mais avançado de organização e articulação, às próprias políticas de saúde”.
} 
básica de prestação de serviços de saúde (Mulin e Neder 1993 citados por BÓGUS 1997, p.19).

Em 1986, num debate realizado em São Paulo, A propósito da Reforma Sanitária, um dos debatedores reconhece a participação como uma diretriz do sistema único e, um princípio fundamental: "é entendida de fato como responsabilidade do exercício do controle social, com a permeabilidade das instituições às pressões, às reivindicações sociais. É o reconhecimento da legitimidade das organizações sociais (....)“ (ASSOCIAÇÃO PAULISTA DE SAÚDE PÚBLICA 1986, p.16).

Ainda que contemplada pela lei constitucional, a implementação das políticas de saúde previstas na reforma sanitária necessitaram da continuidade e aprofundamento de um amplo processo democrático. Assim, a aprovação da Lei Orgânica da Saúde - Lei Federal 8080/90, foi possível graças à articulação das forças políticas nucleadas na Plenária das Entidades de Saúde. Essa Lei regulamentou o SUS, dando destaque a participação social, através das Conferências Nacionais de Saúde e dos Conselhos. Mas logo depois de sua aprovação foi vetada pelo presidente da República, precisamente nos tópicos referentes à participação social.

Uma nova Lei - nº 8142/90 - dispôs, especificamente, sobre a realização das Conferências e Conselhos de Saúde e sobre as transferências automáticas para Estados e Municípios, tornando obrigatório: a criação dos conselhos Estaduais/Municipais de Saúde e Fundos de Saúde (....) GERSCHMAN1995). Essa lei foi aprovada em resposta à pressão e à articulação da Plenária de Entidades.

COÊLHO (1999, p.98) entende a categoria "participação popular (o destaque é nosso) como o conjunto de práticas sociais através das quais a sociedade civil, por intermédio de suas organizações representativas (ou diretamente), coloca-se diante do poder instituído com vistas ao atendimento de suas demandas. Desta forma, a participação popular inevitavelmente implica uma dimensão política”.

\footnotetext{
Para MENDES (1993, p. 113) a "participação social significa, fundamentalmente, uma forma de redistribuição dos poderes técnico, administrativo e político, aproximando-os da periferia dos fatos e das pessoas que passam, em consequência, de objetos a sujeitos desse processo é portanto, fato político, porque representa o exercício de uma capacidade organizativa concreta da população - enquanto sociedade civil - tendo em vista o controle sobre atividades públicas.
} 
Somarriba (1989) é citada por MENDES (1993, p.114) como um dos teóricos que prefere "referir-se ao processo de apropriação institucional pela sociedade civil como participação popular (o destaque é nosso) expressão que reflete a ativação da sociedade civil e com a presença da população, em defesa de seus interesses”.

\begin{abstract}
No campo da saúde, a participação social poderia ser definida como o processo de intervenção da sociedade civil organizada nas deliberações sobre a saúde, na tomada de decisões que têm a ver com a satisfação de suas necessidades, no controle dos processos, assim como na assunção de responsabilidades e observação de obrigações derivadas do desempenho de sua faculdade decisória (MENDES 1993, p.114).
\end{abstract}

Para MENDES (1993) fica claro que a participação social depende da emergência de novos sujeitos sociais com capacidade deliberativa: ela variará de acordo com o grau de maturidade dos regimes democráticos e com o estilo de descentralização vigente.

Para BÓGUS (1997, p.20) o Movimento de Saúde sempre procurou manter um canal de interlocução com a população, independente da participação popular institucionalizada, a fim de poder orientar a atuação daquele pelas demandas populares. "A criação dos conselhos populares de saúde deveriam cumprir um papel tático de incentivo à participação e à organização popular, independentes do Estado e dos partidos políticos e sob a direção e controle da própria população”.

Valla e col. (1993) citados por BÓGUS (1997, p.30) "consideram que, de forma geral, os movimentos populares não costumam ter em sua relação com os órgãos públicos, as informações necessárias sobre os serviços básicos, para subsidiar suas lutas pela aquisição desses serviços em qualidade e de acordo com a sua realidade". No entendimento de BÓGUS ainda, essa capacitação técnica precisa ocorrer com a presença dos movimentos sociais, espaço onde essas questões emergem e, sempre têm em vista ações propositivas.

Para MENDES (1993) no nosso sistema de saúde, a participação nos Conselhos de Saúde deve representar o resultado de um processo de consensualização e controle.

$\mathrm{Na}$ análise de BÓGUS (1997, p.31), diversos trabalhos, recentemente realizados, verificam que ainda existem problemas quanto ao exercício da participação nos espaços institucionais representados pelos conselhos de saúde. 
"Nestes, a interação entre representantes dos órgãos administrativos, os profissionais de saúde e os representantes da comunidade, tem ocorrido com grande dificuldade, especialmente no momento da discussão conjunta sobre as questões relativas às ações de saúde". 


\subsection{A política de formação de recursos humanos em saúde no Brasil}

Anteriormente nos propusemos a recuperar parcialmente a história das políticas públicas em saúde, com o propósito de entendermos a inter-relação mais recente entre a dinâmica social e a formulação de políticas para o setor saúde. Neste momento, utilizando-nos também dos estudos de vários autores, vamos nos aproximar do tema da qualificação dos trabalhadores da saúde, com a finalidade de identificar as características da relação entre as políticas de saúde e as políticas de formação de recursos humanos em saúde no Brasil.

\subsubsection{Antecedentes históricos}

No denominado período colonial brasileiro, no qual as ações de saúde desenvolvidas pelas autoridades locais estavam voltadas para a erradicação e controle das doenças transmissíveis que pudessem prejudicar as exportações, a regulamentação dos cursos de formação, atendendo às necessidades do modelo econômico vigente, voltavam a atuação dos profissionais de saúde para o trabalho de fiscalização e controle sanitário (CHRISTÓFARO 1992; POZ e VARELLA 1994).

O sistema escolar, nesse período, não contemplava a formação de profissionais de nível médio, delegando as estratégias de treinamento para a qualificação dos trabalhadores leigos, aos próprios serviços de saúde, como as Santas Casas.

O processo de industrialização crescente, a partir da década de 30 , mudou o eixo de atuação dos serviços de saúde, voltando-o para os centros urbanos e para o atendimento da massa operária, visando a manutenção da força de trabalho em condições de produção, bem como a reintegração rápida ao processo produtivo além, da estruturação da Previdência Social brasileira. (POZ e VARELLA 1994; BERTOLOZZI e GRECO 1996). O curso de formação do auxiliar de enfermagem, 
por exemplo, foi regulamentado somente em 1946 (CHRISTÓFARO 1992; POZ e VARELLA 1994).

A década de 70 foi um período marcado pela valorização da expansão da produção no setor econômico e de pouca ênfase na formação de recursos humanos na área de saúde no território nacional. Embora o I Plano Nacional de Desenvolvimento (I PND - 1972/74) enfatizasse a necessidade de uma "Política de Aproveitamento dos Recursos Humanos do país como fator de produção e consumo", o que ocorreu de fato foi apenas a ampliação do emprego no setor (ENSP/FIOCRUZ 1982).

Vários estudos (ENSP/FIOCRUZ 1982; NOGUEIRA 1986; CORVINO 1991; POZ e VARELLA 1994) citam a expansão das escolas médicas, notadamente no Brasil, mas também em outros países da América Latina, incentivada por organismos internacionais como a Organização Mundial de Saúde e Organização Pan-americana de Saúde. Ao lado disso, outros organismos internacionais como a CEPAL (Comissão Econômica das Nações Unidas para a América Latina) propuseram a formulação de políticas de desenvolvimento social como mecanismo de enfrentamento do problema da marginalidade de grande parcela das populações. No ano de 1972, marco para as políticas de saúde da América Latina, os Ministros da Saúde aprovaram o $2^{\circ}$ Plano Decenal de Saúde para as Américas, que colocava como principal objetivo, a extensão de cobertura dos serviços à população (ROSAS, 1981) pois nenhum país latino-americano havia conseguido até 1972, preparar e colocar em execução um plano de desenvolvimento de recursos humanos integrado a um plano geral de saúde (CORVINO 1991).

A partir do II PND (1975-79), e da Lei 6.229 (1975) que trata da organização do Sistema Nacional de Saúde, houve um incremento do número de trabalhos interministeriais destinados a estudar a questão da formação dos recursos humanos em saúde no Brasil. Em 1976, foi elaborado por uma equipe de técnicos do Ministério da Educação e Cultura - MEC, Ministério da Saúde - MS, Ministério da Previdência e Assistência Social - MPAS e da Secretaria Especial de Planejamento da Presidência da República - SEPLAN, um documento intitulado Estudo sobre a Formação e Utilização dos Recursos Humanos na Área da Saúde, cujo objetivo principal era "propor diretrizes para as ações que permitam a correção das principais 
distorções que vêm ocorrendo na preparação e utilização de recursos humanos no setor Saúde" (ENSP/FIOCRUZ 1982).

$\mathrm{Na}$ conclusão desse relatório, a exemplo de vários fatos posteriores, nota-se um reconhecimento da necessidade de se integrar o sistema de saúde com o de ensino, declarando então, pela primeira vez, que o objetivo final do aparelho formador só seria alcançado mediante ampla e dinâmica articulação com os órgãos voltados à prestação de serviços de saúde; “a formação dos recursos humanos em saúde no Brasil, embora obedecesse às exigências do mercado e da distribuição de renda, deveria orientar-se, para uma atenção mais voltada às reais necessidades da população" (ENSP/FIOCRUZ 1982; CORVINO 1991).

Um dos problemas apontados referia-se à predominância de pessoal de nível superior (em particular de médicos) nas equipes de saúde em detrimento do pessoal de nível técnico e auxiliar qualificado. A formação daqueles profissionais estava atrelada ao mercado dos grandes centros urbanos, à assistência individual, curativa e especializada oferecida à parcela da população com direito à assistência previdenciária. Entretanto, grande parcela da população não tinha acesso a esse benefício e estava suscetível a um grande número de doenças infecto-contagiosas e endemias que passaram a assolar também as cidades. Enquanto ocorreu, de um lado, um aumento considerável no número de profissionais médicos lançados no mercado em decorrência da expansão das escolas médicas, houve, de outro, uma acentuada absorção pelas instituições de saúde, de mão de obra desqualificada e de baixo custo, representada pelas atendentes (ENSP/FIOCRUZ 1982; NOGUEIRA 1986; VIEIRA e SCUCATO 1988; SANTOS e SOUZA1989).

A política de extensão da cobertura de serviços de saúde está expressa no II PND como única resposta à crise originada pelo milagre brasileiro. Aquela engaja-se no movimento da medicina comunitária enquanto prática alternativa paralela à organização dominante da assistência médica cujos contornos compreendiam a participação comunitária, o privilegiamento da atenção primária, a medicina simplificada, a ênfase na utilização do pessoal auxiliar. Os programas desse modelo tiveram, como objetivo secundário, a formação de recursos humanos na tentativa de suprir a insuficiência ou inadequação técnica dos profissionais existentes (ROSAS 1981; CORVINO 1991). 
No seu processo de implantação, os programas de medicina comunitária incorporaram-se através do MS às Secretarias Estaduais. Em outra vertente, os programas de formação, como uma das variantes de experiência-piloto, assumiam cada vez mais sua natureza acadêmica, formalizando-se posteriormente nos PIDAs Programa de Integração Docente Assistencial (CORVINO 1991).

ROSAS (1981) revela no seu trabalho de pesquisa que a criação do Serviço Especial de Saúde Pública - SESP - em 1942, foi a primeira tentativa expressiva de extensão da cobertura em saúde nas áreas rurais. Em 1960, o SESP foi absorvido pelo governo brasileiro, transformado em fundação - Fundação SESP - e vinculado ao Ministério da Saúde. Eram funções da FSESP, promover nas áreas de expansão, programas de saúde, de saneamento, de treinamento de pessoal técnico e auxiliar e ensino de enfermagem. Em 1977, possuía uma rede de 272 unidades de saúde de complexidade diversa.

Como suporte ao Sistema Nacional de Saúde criado em 1975, e acoplado a um programa de extensão de cobertura, foi elaborado o PPREPS -Programa de Preparação Estratégica de Pessoal de Saúde - que só foi implantado em 1976: programa lançado pelo governo federal, e dirigido inicialmente às populações carentes do nordeste, deu sua maior contribuição ao PIASS (Programa de Interiorização das Ações de Saúde e Saneamento), fruto de ações conjuntas entre os MPAS e do Interior. O PPREPS, através de convênio da OPAS com o MS e MEC, propunha-se a “ 'adequar' a formação de pessoal à realidade do sistema de saúde”. Foi possivelmente, segundo CORVINO (1991), a primeira proposta mais sistematizada e explícita de desenvolvimento de recursos humanos em saúde, elaborada para subsidiar um programa institucional público no Brasil.

CORVINO (1991) recorreu à Declaração de Alma - Ata em 1978, na Conferência Internacional de Atenção Primária à Saúde, que reconheceu a importância dos recursos humanos como um dos importantes aspectos para se alcançar as metas traçadas nos planos de saúde. Vários documentos a partir desse evento, patrocinados na sua maioria pela OPAS/OMS, apontaram a importância do desenvolvimento de políticas e estratégias de preparação de pessoal, através do treinamento, da preparação de Instrutores, da supervisão de apoio e da atenção para a educação continuada. 


\subsubsection{As transformações sociais da década de 80 e o PLE}

A década de 80 representou, como vimos anteriormente, uma significativa mudança no cenário político, no contexto do setor saúde e, consequentemente, nas políticas de formação de Recursos Humanos para os serviços de saúde.

Diante da organização dos serviços de saúde, cuja pirâmide ocupacional tinha a sua base constituída de pessoal sem qualificação profissional, a proporção entre profissionais era inadequada, sobressaindo-se a inversão da relação médicoenfermeiro; tornava-se urgente o preenchimento do vazio ocupacional entre o nível universitário e o pessoal sem qualificação, através da preparação de pessoal de nível de $2^{\circ}$ grau, utilizando, a curto prazo, a via do ensino supletivo para qualificar o contingente de pessoal atuando no setor, bem como incrementando-se a profissionalização regular (ENSP/FIOCRUZ 1982).

Há de se registrar, que o contingente de pessoal sem qualificação representava a essa época $70 \%$ do pessoal empregado no setor (SANTOS e SOUZA 1989; AZEVEDO 1992; OLIVEIRA 1996).

Em 1980, frente a realização da $7^{\text {a }}$ Conferência Nacional de Saúde, cuja finalidade era a implantação de um Programa Nacional de Serviços Básicos de Saúde, havia uma necessidade imperativa de preparação de pessoal auxiliar. Em 1982, o Programa de Desenvolvimento de Recursos Humanos para o Setor Saúde, através do acordo Ministério da Educação e Cultura/Ministério da Saúde/Ministério da Previdência e Assistência Social/Organização Pan-americana da Saúde, elaborou o documento intitulado Recursos Humanos para os Serviços Básicos de Saúde, o qual definiu o denominado Programa de Formação de Pessoal de Nível Médio e de Nível Elementar, o conhecido Projeto Larga Escala.

O Projeto Larga Escala configurava-se como uma alternativa inovadora para qualificar os trabalhadores já empregados nos serviços de saúde. Adotava como princípio pedagógico a realidade da prática dos alunos, utilizava como corpo docente os próprios profissionais da rede de serviços, e garantia aos egressos a identidade profissional mediante o reconhecimento pelo sistema formal de ensino. 
No contexto político, a sociedade brasileira enfrentava uma das suas mais expressivas crises - econômica e da Previdência Social. Vários segmentos sociais organizavam-se reivindicando o acesso igualitário a bens, serviços e participação nas decisões de interesse sociais. Importantes foram as decisões desse período: as eleições diretas, a VIII Conferência Nacional de Saúde - o Projeto da Reforma Sanitária, a Assembléia Nacional Constituinte - a nova Constituição Brasileira - o novo Sistema de Saúde - SUS.

As modificações ocorridas nos serviços de saúde a partir de 1987, tendo por princípios e diretrizes as discussões da Reforma Sanitária e posteriormente, a definição na Constituição Federal e na Lei Orgânica da Saúde da competência do Sistema de Saúde em ordenar a formação de recursos humanos na área da saúde, passaram a demandar reorientações nas políticas de formação e desenvolvimento de pessoal para o setor (SANTANA 1990 ; CORVINO 1991; TEIXEIRA 1993 ; SIMIONI 1993).

Para OLIVEIRA Junior (1990) o debate sobre a administração de RH deixou uma posição secundária e passou a ter papel central em todos os fóruns onde se abordavam questões que envolviam a reorganização dos serviços de saúde. Tratavase, nessa perspectiva, de promover um rompimento com uma visão instrumental de RH: deixar de tratar o trabalhador de saúde como mais um entre os vários insumos necessários ao funcionamento dos serviços de saúde, para repensá-lo como um sujeito ativo de um processo social.

A prática profissional compreendida nesse novo processo social enfatizava a descentralização da gestão da saúde, a municipalização dos serviços, a adoção de modelos assistenciais que priorizassem as ações de vigilância à saúde, mediante a articulação de distintas categorias profissionais assentada sobre uma nova lógica nessas relações.

Trata-se, segundo TEIXEIRA (1993, p.21), do estabelecimento de um pilar para a reforma de sistemas de saúde, - o profissionalismo renovado - que "inclui, aspectos éticos, técnicos e políticos, isto é, a consolidação de uma ética da qualidade, a busca da competência técnica e o compromisso político com resultados, efetividade e respeito aos cidadãos“. 
Para tanto, os autores reconhecem os desafios que necessitam ser superados os quais referem-se a: 1) definição de políticas e estratégias de formação de RHs que possam contribuir para direcionar o Sistema de Saúde, em superação ao modelo assistencial privatista e de acordo com as realidades locais prevalecentes; 2) reorientação da ação conjunta do Ministério da Educação e Cultura, do Ministério da Saúde, e outras Instituições de tal forma que caberia ao MS o estabelecimento das diretrizes para a formação e capacitação de RHs, e ao MEC o cumprimento dessas diretrizes juntos às instituições formadoras; 3) capacitação técnica e gerencial das diversas instâncias de implementação do Sistema de saúde; 4) incursões dos setores da saúde e da educação em torno de um dado projeto de formação de RH que possa transformar-se em um movimento político de maior vulto, responsabilizando o Estado e a sociedade pela qualificação profissional em saúde e impulsionando a compreensão dos alunos e professores acerca da sua participação no processo de produção de serviços de saúde (SANTANA 1990; TEIXEIRA 1993; PAIM 1994).

Para SANTANA (1990) o debate sobre a formulação de políticas de recursos humanos nos serviços de saúde deveria assentar-se sobre dois pontos fundamentais: a recuperação da dignidade e a busca da identidade do trabalhador de saúde que, dada a sua natureza humana, é autor da sua própria história. Além disso, esse mesmo autor ressaltava os limites das intervenções sobre os recursos humanos cuja potencialidade não é suficiente, para isoladamente modificar os serviços de saúde.

Reiterando as proposições do projeto da Reforma Sanitária Brasileira e as deliberações da VIII CNS frente à constituição do SUS e sua competência para ordenar a formação de RH, buscamos resgatar algumas experiências que contribuíram para subsidiar as discussões acerca das políticas de formação de RH para o setor saúde.

Ao longo dos anos 80, através do financiamento estabelecido pelo Programa Metropolitano de Saúde - PMS - e resultante do acordo interministerial, foi trazido para São Paulo o Programa de Formação em Larga Escala para viabilizar a expansão dos serviços básicos de saúde. No estudo realizado por CORVINO (1991) o PMS desempenhou um importante papel na introdução de um processo de planejamento e organização da área de RH na Secretaria de Estado da Saúde. 
O Programa de Formação em Larga Escala representou nesse período um papel particular frente à problemática da desqualificação do pessoal de nível médio e elementar empregado nos serviços de saúde e, em especial para a área de enfermagem, além de desenvolver a educação continuada dos profissionais envolvidos com a formação - os Instrutores. Outros Estados brasileiros também implantaram esse Projeto: Minas Gerais, Espírito Santo, Piauí, Goiás, Pernambuco, Maranhão (TORRES 1994).

A partir da realização da I Conferência Nacional de Recursos Humanos, em 1986, é possível considerar alguns saldos organizativos com relação a formação de pessoal de nível médio dos quais apontamos o credenciamento das Escolas Técnicas de Saúde do SUS - ETSUS. Dentre estas, destaca-se a Escola Técnica de Saúde Joaquim Venâncio vinculada à Fundação Oswaldo Cruz, no Rio de Janeiro, que viabilizou a implementação de uma proposta de formação de RH de nível médio, mediante o desenvolvimento de diversos cursos de qualificação profissional comprometidos com a reorganização dos serviços e com os princípios da reforma sanitária (ESCOLA POLITÉCNICA DE SAÚDE JOAQUIM VENÂNCIO, 1996).

No ano de 1998, foi divulgada uma iniciativa do MS - o Projeto de Profissionalização dos Trabalhadores da Área de Enfermagem (PROFAE) destinada a profissionalizar os trabalhadores empregados nos estabelecimentos públicos, privados ou filantrópicos, que desenvolvem ou desenvolveram nos últimos 18 meses, atividades na área de enfermagem. Trata-se de um projeto com investimento internacional através do Banco Interamericando de Desenvolvimento (BID), do Fundo de Amparo ao Trabalhador (FAT) e do Tesouro Nacional, planejado para desenvolver-se no período de 2000 a 2003, promovendo a Complementação do ensino fundamental e a qualificação profissional de cerca de 225 mil trabalhadores cadastrados no território nacional (PROFAE, 2000).

Reconhecemos que, ao longo de praticamente duas décadas, não houve significativa transformação na característica ocupacional do setor saúde, no que se refere à qualificação profissional do pessoal auxiliar. Apesar do aumento do número de Auxiliares de Enfermagem, ainda temos um enorme contingente de atendentes empregados nos serviços de saúde sem a devida qualificação 
PAIM (1994) ao analisar as propostas de mudanças na formação do pessoal de saúde, constata resultados tímidos frente às demandas constituídas pela reorientação do sistema de saúde. No seu entendimento, pensar saúde numa concepção ampliada que extrapole a assistência e demande a articulação de políticas públicas numa perspectiva transetorial, permite à saúde estabelecer-se como eixo orientador das políticas sociais enquanto não prevalecer uma concepção globalizante do desenvolvimento da sociedade brasileira.

Esse processo permitirá a transformação de um movimento cultural em torno de um dado projeto de formação de RHs em um movimento político de maior vulto que alterará a correlação de forças institucionais instaurando um novo patamar de articulação ensino - serviço, que reforce a pertinência de articular e aproximar os mundos do ensino e do trabalho, bem como recuperar e valorizar a dimensão humana do agente em formação (PAIM 1994, cap.10 e 11).

\subsubsection{As atendentes de enfermagem e o PLE}

Nesse momento em particular, nos ocuparemos em expor algumas especificidades dos trabalhadores de nível médio empregados no setor saúde - as atendentes de enfermagem - e suas relações profissionais na equipe de enfermagem.

O processo de expansão da rede de serviços de saúde no Brasil, e o investimento particular no setor privado, provocou o aumento de número de leitos hospitalares, a expansão de unidades de assistência ambulatorial e da rede básica de saúde. Para viabilizar as ações assistenciais nesses locais, foi necessária a absorção, acentuadamente nos anos 80, de um enorme contingente de pessoal de baixa qualificação e de baixa escolaridade, a quem foi atribuída a responsabilidade de desenvolver atividades ditas "auxiliares" e de apoio (SANTOS e col.1987; SANTOS e col.1988).

Esses trabalhadores prestavam serviço em diversas áreas: administrativa, apoio - diagnóstico e assistencial e, inúmeras foram as denominações atribuídas a esses profissionais, que representaram de acordo com os dados divulgados por 
diferentes autores, $70 \%^{6}$ do pessoal empregado no setor saúde nos anos 80 (VIEIRA e SCUCATO 1988; VIEIRA 1990; AZEVEDO 1992; OLIVEIRA 1996).

Desse total, as profissionais que vieram a compor as equipes de enfermagem na função de atendentes, representavam $50 \%{ }^{7}$ do pessoal empregado (VIEIRA e SCUCATO 1988; SANTOS e col.1988; SECRETARIA MUNICIPAL DA SAÚDE, 1989). Eram suas características: a procedência das classes sócio-econômicas mais desfavorecidas; a baixa escolaridade - a maioria não tinha o $1^{\circ}$ grau completo; a predominância do sexo feminino, cuja possibilidade de emprego poderia estar assegurada junto a esse setor de prestação de serviços em decorrência do seu nível de exigência para o trabalho (MACHADO 1986; NOGUEIRA 1986; SECRETARIA MUNICIPAL DA SAÚDE 1989; ALMEIDA 1996; ABEn 1999; NOCA 1999).

Dentro da equipe de enfermagem as atendentes correspondiam à categoria de maior representação, e para quem ficavam atribuídas as tarefas "rotineiras" mais

\footnotetext{
${ }^{6}$ Vários autores vêm divulgando dados a esse respeito 1) MÉDICI (1987, p. 45) apresenta uma tabela intitulada Profissional em Saúde no Brasil 1970-80, cuja fonte foi o IBGE/ENSP através da Pesquisa sobre Recursos Humanos para a Saúde no Brasil, na qual o nível médio e elementar é representado nos anos 70 e 80 , respectivamente, por $72,35 \%$ e $70,58 \%$; 2) Para VIEIRA e SCUCATO (1988, p. 36-7) o total da força de trabalho em saúde em 1980, era composto por 233.000 trabalhadores sendo que cerca de $70 \%$ por profissionais de nível médio e elementar; 3) Para Nogueira (1986) citado por AZEVEDO (1992, p.2) a análise da força de trabalho em saúde do Brasil demonstra expressivo percentual $70,58 \%$ de trabalhadores com formação de nível médio e elementar, sem qualificação profissional; 4) Para VIEIRA (1990, p.62) os níveis médio e elementar participam, de forma intensa, da força de trabalho em saúde, representando, em 1984, 60\% dos empregos em saúde; 5) Para OLIVIERA (1996, p.33) os estudos sobre a força de trabalho em saúde no final dos anos 70 , evidenciam uma polarização entre profissionais altamente qualificados - médicos, cerca de $30 \%$ do total de empregos, e ocupacionais sem qualificação nenhuma - atendentes compondo os quase $70 \%$ restantes; 6) Para a SECRETARIA MUNICIPAL DA SAÚDE-CEFOR (1993, p. 4) no Brasil, os serviços de saúde possuem um grande contingente de pessoal de nível médio e elementar sem qualificação profissional que compunham quase $70 \%$ da totalidade do pessoal empregado em serviços de saúde no país; 7) Para ALMEIDA JLT(1996, p.53) a categoria que teve maior incorporação no mercado de trabalho foi a do atendente de enfermagem, que em 1980, representava $71,24 \%$ do total de empregos de nível médio e elementar na saúde.
}

${ }^{7}$ Da mesma forma, vários autores vêm divulgando dados a esse respeito: 1) Para VIEIRA e SCUCATO (1988, p.37) dentre os profissionais de nível médio e auxiliar que constituem a força de trabalho em saúde, $50 \%$ são profissionais com atividade na enfermagem; 2) Para SANTOS e col. (1988, p.203-4) a enfermagem brasileira foi a categoria, em função de sua representação majoritária no setor (cerca de $50 \%$ da força de trabalho em saúde),que certamente sofreu o maior impacto do projeto de modernização do setor (....); 3) Para a SECRETARIA MUNICIPAL DA SAÚDE (1989, p.5) o contingente de trabalhadores sem qualificação específica, basicamente os atendentes de enfermagem, representa mais de $50 \%$ da força de trabalho; 4) Para TORRES (1994, p.5-6) do contingente de trabalhadores sem qualificação específica para o trabalho em saúde, cerca de $50 \%$ compõe a equipe de enfermagem. 
desgastantes; proporcionalmente, a $2^{\mathrm{a}}$ maior categoria era a das auxiliares de enfermagem - profissionais com escolaridade mínima de $1^{\circ}$ grau - além da qualificação através do curso profissionalizante, a quem eram atribuídas atividades específicas e, em menor número, a categoria das enfermeiras - profissionais com formação de nível superior -, responsáveis pela gerência, supervisão e controle do processo de trabalho das demais categorias.

Numa pesquisa realizada pelo Conselho Federal de Enfermagem 1982-1983, as atendentes representavam $63,8 \%$ do total da força de trabalho em enfermagem no Brasil. Para o Conselho Regional de Enfermagem - Seção São Paulo, nos anos de 1980 e 1989, haviam os seguintes cadastros:

\begin{tabular}{|c|c|c|c|}
\hline & 19 & 19 & \\
\hline Enfermeiro & 5272 & 14241 & $15.26 \%$ \\
\hline Técnico de Enfermagem & 1617 & 5386 & $5.77 \%$ \\
\hline Auxiliar de Enfermagem & 13657 & 28899 & $30.97 \%$ \\
\hline Atendente & $\mathrm{n} / \mathrm{c}$ & 44773 & $47.98 \%$ \\
\hline
\end{tabular}

$\mathrm{Na}$ nossa compreensão, as categorias de nível médio e elementar são responsáveis por atividades que exigem certo grau de autonomia e julgamento e não são, na verdade, apenas executores de tarefas de caráter manual, indicadas por profissionais universitários.

\begin{abstract}
Há um entendimento de que o desenvolvimento dessa prática requer certo grau de autonomia, expresso pela realização de atos que exigem capacidade de observação, juízo e decisão. Desta forma, esses profissionais não se comportam como meros auxiliares, dotados de um papel acessório, como ocorre na tradicional divisão do trabalho no setor produtivo, ao contrário, gozam de autonomia de intervenção que é tanto maior quanto menos complexa for a unidade de saúde, ainda que suas atividades requeiram supervisão por parte de profissionais de formação universitária (MINISTÉRIO DA SAÚDE 1982;p.7).
\end{abstract}

Assim, a assistência de enfermagem prestada à população instituiu-se num processo de trabalho fragmentado, realizado por categorias socialmente diferenciadas, em sua maior parte por profissionais formalmente desqualificados. Cada categoria integrante vem cumprindo um conjunto de tarefas, de tal maneira 
isoladamente que se perde a noção de conjunto de seu papel social (VIEIRA e SCUCATO 1988; TORRES 1994):

\begin{abstract}
É importante ressaltar que esses trabalhadores sustentaram e sustentam a assistência de enfermagem no país e sua prática empírica, desprovida de conhecimentos e técnica, compromete os serviços, pois a esse trabalhador, até o momento foram negadas as condições para a necessária qualificação. Somam-se a este fato a desvalorização do seu trabalho que é extremamente mal remunerado; nesse sentido, esse grupo de trabalhadores faz parte da dívida social que necessita ser resgatada no processo de democratização da sociedade brasileira (SANTOS e col. 1988, p. 294).
\end{abstract}

No plano social, esses trabalhadores "não possuem identidade de categoria profissional podendo constituir-se em clientela cativa das instituições, sem possibilidade concreta de mobilidade de emprego no território nacional" (SANTOS e col. 1988, p.205).

Nesse contexto institucional, passa a vigorar a partir de 25 de junho de 1986, a Lei $\mathrm{n}^{\circ} 7.498$ que estabelece o exercício profissional da enfermagem à Enfermeira, à Técnica de enfermagem, à Auxiliar de enfermagem e à Parteira. "Ao pessoal que se encontrava executando tarefas de Enfermagem, em virtude de carência de recursos humanos de nível médio nesta área, sem possuir formação específica, foi emitida autorização para exercer atividades elementares de Enfermagem, durante o prazo de dez anos a contar da promulgação da Lei" (Lei n ${ }^{\circ} 7.498$ de 25.06.86).

É esse o panorama singular dos trabalhadores de enfermagem nos anos 80, que determinou às instituições de saúde a definição de políticas que corrigissem as distorções dessa área e assumissem a responsabilidade pela formação profissional desse pessoal (VIEIRA e SCUCATO 1988). 


\section{TRAJETÓRIA METODOLÓGICA DA PESQUISA}

\subsection{Procedimentos para apreensão do objeto}

Para apreender o objeto desta pesquisa, optou-se pelo uso de instrumentos qualitativos complementares: análise documental e entrevistas. As entrevistas semiestruturadas foram realizadas com profissionais que atuaram na área de recursos humanos, especialmente, aqueles que atuaram no desenvolvimento do PLE na referida administração. O roteiro de entrevista foi previamente elaborado para nortear a pesquisadora, com a flexibilidade necessária para garantir o reordenamento e a decodificação das perguntas, de acordo com as respostas dadas pelos entrevistados (MINAYO, 1994), permitindo-lhes a maior liberdade possível no encaminhamento da interação pesquisadora-entrevistada (LUDKE e ANDRÉ 1986). Tal eleição percorreu um caminho de "garimpagem" que, fundamentalmente, procurou seguir os encaminhamentos de uma:

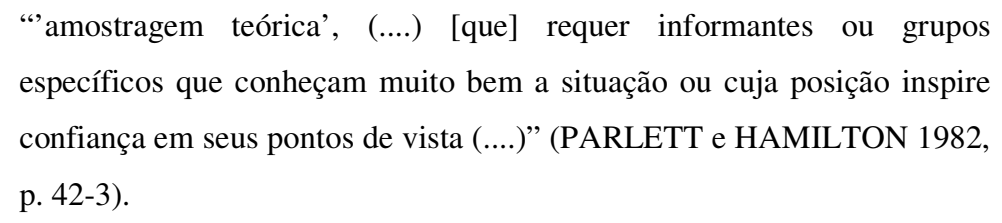

Os documentos foram selecionados mediante sua pertinência em relação ao contexto político-administrativo analisado e, especificamente, mediante sua focalização na prática adotada pela administração na formação de recursos humanos, no entendimento de que "a análise documental pode se constituir numa técnica valiosa de abordagem de dados qualitativos, seja complementando as informações obtidas por outras técnica, seja desvelando aspectos novos de um tema ou problema" (LÜDKE e ANDRÉ 1986, p. 38).

Foram então selecionados os seguintes documentos:

- Acordo MEC/MS/MPAS/OPAS. Programa de formação em larga escala de pessoal de níveis médio e elementar para os serviços básicos de saúde. 
- Ministério da Saúde. Recursos humanos para serviços básicos de saúde: formação de pessoal de níveis médio e elementar pelas instituições de saúde. Brasília (DF): Centro de Documentação do Ministério da Saúde; 1982.

- Ministério da Saúde. Responsabilidades institucionais no desenvolvimento do Projeto “Larga Escala”. Brasília (DF): Grupo Assessor Principal; 1983.

- Secretaria Municipal da Saúde. Proposta de formação de pessoal de níveis elementar e médio na Secretaria Municipal de Saúde. São Paulo: 1989.

- São Paulo (Município). Decreto n.28.625, de 30 de março de 1990. Cria o Centro de Formação dos Trabalhadores da Saúde - CEFOR, vinculado ao Centro de Recursos Humanos da Secretaria Municipal da Saúde. Diário Oficial do Município de São Paulo, São Paulo, 31 de março de 1989. p.1

- Brasil. Lei n.7.498, de 25 de junho de 1986. Dispõe sobre a regulamentação do exercício da Enfermagem e dá outras providências. Diário Oficial da República Federativa do Brasil, Brasília, 26 jun. 1986. Seção I, p.9.273.

\subsection{As entrevistas}

\subsubsection{Os sujeitos pesquisados}

Durante os meses de junho, julho, setembro e outubro de 1999, foram entrevistados profissionais que, durante a gestão municipal de 1989-1992, participaram do projeto de formação em dois níveis: central e regional. Dessa forma, 2 dos entrevistados faziam parte da coordenação do Centro de Formação dos Trabalhadores de Saúde (nível central) e 5 desenvolviam atividades junto ao projeto no nível regional, sendo que 3 deles participaram diretamente na função de instrutorcoordenador e 2 participaram na função de gerente ( 1 da equipe de recursos humanos e 1 do Serviço de Enfermagem).

Dado o fato de que a atividade de formação de recursos humanos fora descentralizada nas administrações regionais e considerando que o desenvolvimento dessas práticas fora diferenciado em cada uma das regiões - ajustando-se às particularidades internas nos diferentes Distritos Sanitários que compunham a região 
- no processo de escolha dos sujeitos de pesquisa, tentando acompanhar essa diversificação, selecionamos entrevistados em diferentes regiões do município cujas características consideramos fundamentais para expressar esse quadro de heterogeneidade. Assim, os entrevistados foram trabalhadores alocados: 2 na região leste, integrados na ARS-5 - região periférica do município com alto grau de exclusão social (SPOSATI, s/d) e intenso envolvimento no movimento de saúde que deflagrou a criação do SUS (JACOBI 1993) - considerados profissionais com alto grau de envolvimento no que se refere aos propósitos de transformação do novo modelo de assistência a ser desenvolvido nessa gestão e diferenciadamente compromissados em aceitar o desafio de trabalhar em condições precárias de organização e recursos; 1 da região leste, integrado na ARS-4 - mais próxima da região central, com menor grau de exclusão social (SPOSATI s/d) e menor envolvimento no movimento social por saúde - considerado um profissional com agilidade administrativa para a implementação das diretrizes da Secretaria Municipal de Saúde na área hospitalar; 2 da ARS-10 - região sul do Município, uma área também considerada carente, com envolvimento nos movimentos sociais, inclusive, por saúde (JACOBI 1993) - sendo 1 instrutora-coodenadora do PLE do distrito que atingiu a meta de formação de todos os atendentes da rede e 1 técnica da equipe de recursos humanos encarregada de viabilizar a implementação do PLE na região, que por ter assumido uma função mais abrangente foi identificada como um elemento chave para atingir as metas do projeto político de formação de recursos humanos da Secretaria Municipal de Saúde.

\subsubsection{Os roteiros de entrevista}

Dois tipos de roteiros foram utilizados para a realização das entrevistas: um para o nível central e um para o nível regional. Tomamos como referência as recomendações de PAYNE (1951). Os roteiros foram previamente testados e aprimorados com um teste piloto efetuado com enfermeiras que participaram do programa de treinamento e que não forma incluídas como sujeito de pesquisa. 


\section{Roteiro de entrevista para o nível central}

\section{Sobre o CEFOR}

1. Quais eram as diretrizes políticas da gestão do município? Quais eram as diretrizes políticas da Secretaria Municipal de Saúde?

2. Quais foram as prioridades estabelecidas por essa gestão em saúde?

3. Como foi vista a questão da formação de recursos humanos em saúde?

4. Fale sobre a formação do CEFOR: início das atividades, propostas, objetivos.

5. Qual foi a sustentação teórico-metodológica do CEFOR, suas metas a curto, médio e longo prazos; o entendimento sobre recursos humanos em saúde; modelo assistencial; conceito de saúde-doença, etc.?

6. Quais as dificuldades enfrentadas no processo de implementação do CEFOR, para atingir os objetivos propostos?

7. Como a enfermagem participou desse processo?

8. Quais as modificações ocorridas em função da nova administração 93-96?

\section{Sobre o PROJETO LARGA ESCALA}

9. O que foi o PLE -SP?

10.Quais foram as mudanças ocorridas a partir da proposta original do Ministério no período 89-96?

11.Quais foram as adaptações feitas nas diferentes regiões/ARS?

12.Em quais regiões/região o PLE se implantou em maior profundidade e com maior abrangência?

13.Descreva os problemas/dificuldades detectados nessa implantação/implementação.

14.Como o serviço absorveu e se estruturou em decorrência da formação em serviço?

15.Quais as transformações que você vê no desenvolvimento do PLE no período 89$96 ?$

\section{Roteiro de entrevista para o nível regional}


1. Qual foi o seu envolvimento com o Projeto Larga Escala? (motivações, responsabilidade(s), cargo que ocupava)?

2. O que era o PLE? Quais eram os seus objetivos? A que ele se propunha?

3. Em que contexto o PLE foi implementado em São Paulo?

4. Você avalia que o PLE contribuiu para a implementação das diretrizes do SUS? Por quê?

5. Quais os conteúdos e estratégias desenvolvidos no PLE que você considera estarem relacionados com essas diretrizes?

\subsection{Análise dos resultados}

A análise dos documentos e das entrevistas (nível central e regional) seguiram os encaminhamentos de uma análise temática. A análise temática foi realizada de acordo com as orientações de BARDIN (1977, p.105) que vê o tema [como] "a unidade de significação que se liberta naturalmente de um texto analisado segundo certos critérios relativos à teoria que serve de guia à leitura".

Seguindo as orientações compiladas por LUDKE e ANDRÉ (1986, p. 48), percorremos o caminho de categorização e "de codificação, isto é, uma classificação dos dados de acordo com as categorias teóricas iniciais ou segundo conceitos emergentes".

Nesse sentido, a análise temática privilegiou o reconhecimento de conteúdos que expressassem os princípios e as diretrizes do SUS: descentralização, universalidade, integralidade, equidade e participação popular.

Em seguida, apoiando-nos na consideração de que o "referencial teórico do estudo fornece geralmente a base inicial de conceitos a partir dos quais é feita a primeira classificação dos dados. Em alguns casos, pode ser que essas categorias iniciais sejam suficientes, pois sua amplitude e flexibilidade permitem abranger a maior parte dos dados" (LUDKE e ANDRÉ 1986, p. 48), estabelecendo "articulações entre os dados e os referenciais teóricos da pesquisa, respondendo às questões da pesquisa com base nos seus objetivos” (GOMES 1994, p. 78-9).

Os resultados serão apresentados em dois momentos: no capítulo 4, tratamos de analisar a apropriação dos princípios e diretrizes do SUS na política de saúde da gestão municipal: a criação do Centro de Formação dos Trabalhadores em Saúde 
(CEFOR) e seus encaminhamentos quanto à qualificação dos trabalhadores, principalmente, através da análise de documentos; no capítulo 5, tratamos da prática de qualificação dos trabalhadores de saúde nessa gestão através dos dados provenientes das entrevistas. 


\title{
4. O PLANO DA POLÍTICA: APROPRIAÇÃO DOS PRINCÍPIOS E DIRETRIZES DO SUS NO CONTEXTO DA GESTÃO MUNICIPAL DO PT
}

\subsection{A descentralização e o governo Luiza Erundina}

Sentimos necessidade, num primeiro momento, de buscar na bibliografia referente a essa gestão municipal, a discussão sobre seus encaminhamentos e entendimentos a respeito dos princípios e diretrizes do SUS. No caso brasileiro, as análises pós-LOS têm mostrado uma série de obstáculos de ordem política que dão a marca de retrocesso para a implementação do SUS. A orientação neoliberal do atual Estado brasileiro tende a minar e recrudescer as tentativas de implementação do SUS. Segundo LAURELL (1995, p.162-7) o discurso político-ideológico do neoliberalismo proclama

\begin{abstract}
a redução do Estado às funções relacionadas com o bem-estar social permitindo a ele só intervir com o intuito de garantir um mínimo para aliviar a pobreza e produzir serviços que o setor privado não pode ou não quer produzir(....) As estratégias criadas para reduzir a ação estatal objetivam destruir as instituições públicas para estender os investimentos privados a todas as atividades econômicas rentáveis,(....) o que só ocorre quando os serviços fornecidos pelo setor público são tidos como insuficientes ou de má qualidade. A descentralização neoliberal não tem por objetivo democratizar a ação pública, mas, principalmente, permitir a introdução de mecanismos gerenciais e incentivar os processos de privatização(....) (LAURELL 1995, p.174).
\end{abstract}

Assim, se a lei que criou o SUS representou avanços no processo de descentralização, a sua implementação esteve sempre limitada de um lado, pela manutenção do poder decisório na esfera central e, de outro, pela restrita regulamentação do repasse financeiro (SILVA 1996, p.82-3; ELIAS 1996).

Apesar de um forte apelo da experiência paulistana do governo petista 1989-1992 - rumo à descentralização, vários foram os empecilhos e dificuldades encontradas na sua implementação. Além das questões políticas mais gerais, pode-se apontar: a existência de um "sistema de secretarias municipais centralizador inclusive a secretaria da saúde; o clientelismo histórico dentro do serviço público; o 
corporativismo dos servidores, a desmoralização da administração pública;(....)" (BITTAR 1992).

No estudo realizado por OLIVER (1990) sobre a atenção à saúde da pessoa portadora de deficiência no sistema de saúde, no município de São Paulo, a autora obteve junto aos profissionais dessa rede de serviços, o entendimento de que as necessidades de saúde dessa população específica, devam ser resolvidas na própria rede básica, buscando-se a inserção das ações de saúde juntamente às demais ações desenvolvidas nas unidades, que devem estar próximas dos locais de trabalho e moradia dessa população com o intuito de oferecer atendimento o mais próximo possível da realidade dessas pessoas, desfavorecendo sua segregação, respeitando suas especificidades, mediante o treinamento dos recursos humanos (p. 73).

Os dados obtidos por essa mesma pesquisadora, junto aos profissionais do nível Federal que atendem à clientela portadora de deficiência, também ressaltam a necessidade da descentralização do atendimento como fator importante para facilitar o acesso da clientela. Além disso, para a garantia do atendimento, em resposta às especificidades e/ou complexidades das necessidades dessa população, o sistema de saúde deveria priorizá-la através de maior dotação orçamentária às unidades que desenvolvam algum tipo de ação, assim como a contratação de profissionais e a ampliação de espaço físico de trabalho (p.106).

TELESI JUNIOR (1998), ao analisar a política municipal de saúde no mesmo período do nosso estudo, reafirma o compromisso dessa com a implantação do SUS mediante a implementação da diretriz da descentralização na busca do fortalecimento do nível local, através de uma estrutura gerencial e administrativa modificada e integrada a um quadro de pessoal devidamente qualificado e motivado.

Nesse trabalho de pesquisa houve um reconhecimento que as mudanças pretendidas pela Secretaria Municipal de Saúde dependiam da política de pessoal e da sua valorização. Era pressuposto básico dessa política "a capacitação e a profissionalização do pessoal feita no sentido de resgatar, no trabalhador, a consciência de seu valor, não só pela melhoria do salário, mas também pela importância de sua prática (p. 52)".

$\mathrm{Na}$ opinião dos dirigentes entrevistados nesse estudo, para 
que o processo de descentralização pudesse vir a prosperar, seria imprescindível a definição das competências específicas das autoridades regionais e distritais, com estabelecimento dos graus de autonomia de cada nível decisório. Também foi citado a questão da autonomia dos DS que ficou aquém das expectativas, pois não haviam Unidades Orçamentárias e nem cargos em número compatível com o novo desenho organizacional (p.124). Além disso, a SMS foi a Secretaria com maior ímpeto e iniciativa para a democratização e foi prejudicada em suas diretrizes descentralizadoras devido ao conflito interno descentralização - centralização - existente no interior do governo municipal (p.151).

\subsection{A universalidade e o governo Luiza Erundina}

A principal intenção da Secretaria Municipal da Saúde, no período de 1989 - 1992, era a implantação do SUS no município de São Paulo. Na política de municipalização, a universalização da cobertura e a equidade foram as duas preocupações centrais dos dirigentes. Para enfrentar o compromisso da expansão da cobertura de modo eqüitativo, a Secretaria realizou a reforma administrativa, implantou novas unidades, dobrou o número de servidores, investiu no desenvolvimento do pessoal e desenvolveu esforços pela municipalização dos serviços de saúde (TELESI JUNIOR 1996, p.165-70).

Essa administração do município de São Paulo, assim como a administração de outros municípios brasileiros do governo petista inovou no desenvolvimento da gestão na área da saúde mediante alguns mecanismos: aumento da parcela do orçamento municipal destinada à saúde; aumento significativo do número de leitos hospitalares; ampliação da rede de Unidades Básicas de Saúde; ampliação da capacidade operativa dessas Unidades (ampliando o número de UBS que funcionavam com o $3^{\circ}$ turno de atendimento) além da implantação de diversas atividades e ações assistenciais e educativas (BITTAR 1992). Todas essas modificações tiveram, em última análise, a finalidade de ampliar a cobertura assistencial da população.

\subsection{A integralidade e o governo Luiza Erundina}


A delegação de poder e autonomia às estruturas administrativas criadas: as ARS's e os DS's, permitiu a implementação da regionalização e a hierarquização dos equipamentos de saúde afim de que as necessidades de saúde da população pudessem ser atendidas em serviços diferentes voltados para a complementaridade e complexidade ascendente das ações.

Permitiu também que se encaminhassem os esforços técnico-políticos dos dirigentes na busca das mudanças das práticas assistenciais com o objetivo de atingir uma assistência integral: capacitação técnica e gerencial das equipes, incorporação de tecnologias mediante a apropriação dos conhecimentos da epidemiologia e da vigilância sanitária, o desenvolvimento de trabalhos coletivos enfocando a interdisciplinaridade e buscando, o desnudamento da realidade do território e dos grupos populacionais com maior risco de adoecer e morrer, ampliando o campo de ação através das práticas da saúde coletiva com enfoque multissetorial (TELESI JUNIOR, 1998).

$\mathrm{Na}$ pesquisa realizada por TELESI JUNIOR (1998) uma parcela dos funcionários entrevistados reconhece que a diretriz da integralidade só poderia ser atingida mediante a integração da equipe interdisciplinar. Fora da Instituição, as ações se caracterizaram como episódicas e pontuais. Mencionaram práticas sanitárias integradas entre a saúde, a Educação, o Bem-Estar Social, a Cultura e o Esporte. (....) com as escolas, com as creches, com as ONG's, com associação de moradores, entre outras.

Tanto para os funcionários como para os dirigentes, "apesar do esforço da Secretaria para encontrar meios de integração entre os funcionários, a população e outros setores para enfrentar os problemas de saúde, essa diretriz não conseguiu produzir os resultados esperados" (TELESI JUNIOR 1998, p.88). Uma forte razão para esse tipo de dificuldade encontrada por essa gestão municipal, é sustentada pelo caráter político do comando central do governo, que não conseguiu dar continuidade às ações de caráter intersecretarial, através dos Núcleos Regionais de Planejamento 
- $N R P^{8}$ - que buscavam respostas comuns para resolução dos problemas de saúde mediante a identificação dos determinantes e das ações conjuntas de intervenção.

\subsection{A equidade e o governo Luiza Erundina}

Como vimos anteriormente, os dois grandes objetivos da administração pública municipal no período 1989 - 1992 eram: governar para a maioria, com uma inversão de prioridades, e governar com participação popular.

Desde o início da gestão, para caracterizar o primeiro dos temas foi utilizado o lema "governo para todos", como forma de expressar que agora, ao contrário das outras gestões, o governo deixaria de se realizar para uma minoria.(....) Não se tratava de governar igualmente para a elite e para os trabalhadores, mas exatamente o contrário. Pretendia-se então, governar para todos, privilegiando a maioria, invertendo as prioridades que historicamente tinham favorecido os que possuiam melhor nível de vida buscando dessa forma, atender a parcelas da população que dispunham de menor capacidade de organização e de pressão por mais e melhores serviços (SADER 1992, p.23-4).

No setor saúde em particular, há um reconhecimento de que a administração

municipal comandou movimentos associados na busca de justiça social: tentou-se

criar uma certa tecnologia, que fosse baseada numa visão mais epidemiológica, ou seja, tentou-se construir modelos de intervenção, com essa orientação, para resolver os problemas de saúde, atingir os grupos mais desfavorecidos (....) Buscou-se privilegiar a população mais carente, ao fortalecer o serviço público, ao montar unidades mais consistentes, com maior número de profissionais, com equipes multiprofissionais(....) (TELESI JUNIOR 1996, p.116-7).

Alguns dos dirigentes entrevistados por TELESI JUNIOR (1998) analisaram a política municipal de saúde - no período 1989 - 1992 -numa perspectiva de enfrentamento às iniquidades: "a prioridade colocada para aqueles setores mais excluídos; a expansão dos serviços em direção à periferia; o modo de pensar os problemas de saúde; a política de pessoal e de investimento(...) Se você junta a

\footnotetext{
${ }^{8} \mathrm{NRP}$ : esfera de decisão de gestores intersecretariais, que passa a funcionar a partir de março de 1989, em cada uma das Administrações Regionais. Tratou-se de uma proposta de planejamento integrado no nível local, encabeçada pela Secretaria das Administrações Regionais - SAR e pela Secretaria de Planejamento (TELESI JUNIOR, 1998).
} 
Saúde, com a creche, com a escola pública, chegamos à conclusão que a administração promoveu a equidade" (TELESI JUNIOR 1998, p.116).

\subsection{A participação popular e o governo da Luiza Erundina}

O projeto de governo do Partido dos Trabalhadores pressupõe, para ser implantado, uma radical modificação na maneira como o Estado exerce suas funções: de reprodução e acumulação no plano econômico, de coerção e legitimidade no plano político. "A ocupação de espaços no aparelho de Estado supõe a participação popular para garantir que a prática política administrativa esteja a serviço da correlação de forças entre classes populares e dominantes” (BITTAR 1992, p.22).

A proposta de um governo democrático e popular significa um processo de descentralização deste poder, o qual inicialmente se materializou na proposta de conselhos populares. Ao contrário da prática autoritária ou populista, o PT tem construído uma cultura política cuja referência principal são os direitos. Em outras palavras, a população, à medida que reconhece seus direitos, tem as referências para uma nova relação de controle e fiscalização das ações. Essa proposta de governo tem a expectativa que a participação popular cresça à medida que a população passe a compreender o sentido político deste ato e avalie o seu retorno em termos de conquistas na melhoria de sua qualidade de vida e de seus direitos individuais e coletivos (BITTAR 1992, p.24).

O entendimento do governo democrático e popular a respeito da participação popular na gestão municipal, é a de configuração de uma mudança da qualidade de participação; a qual favorece a constituição como sujeito coletivo de uma alternativa popular para toda a sociedade. "Cabe ao movimento popular se constituir nesse sujeito" (BITTAR 1992, p.25).

Nos diversos municípios onde o Partido dos Trabalhadores constituiu-se governo, a questão da democratização da gestão dos serviços de saúde configurou-se

como uma das suas marcas tendo sido estimulada com bastante intensidade a participação dos usuários e dos trabalhadores de saúde na constituição dos conselhos 
municipais de saúde e de conselhos gestores de unidade de saúde (BITTAR 1992, p.142).

Esse modo característico de trabalhar resultou num leque ampliado de mudanças estruturadas

\begin{abstract}
a partir da implantação de atividades mais dinâmicas (como, por exemplo, trabalho em grupo além do atendimento individualizado), da discussão de temas de saúde junto à população como forma de socialização do conhecimento técnico, até a realização de assembléias, plenárias e conferências municipais, como espaços de deliberação das diretrizes e prioridades da política de saúde (BITTAR 1992, p.142).
\end{abstract}

$\mathrm{Na}$ caracterização do governo municipal realizada por TELESI JUNIOR (1998),

o governo Luiza Erundina quando assumiu a Prefeitura da mais importante cidade do país declarava intenções de mudar as estruturas políticas administrativas vigentes e chamou para si as responsabilidades de priorizar, na esfera municipal, as políticas sociais de interesse coletivo, a partir do estímulo à interlocução e interação com movimentos populares.(....) Procurou instaurar mecanismos inovadores de relação e de comunicação entre o poder executivo e as representações sociais. Para racionalizar o uso dos recursos e aumentar a eficiência da máquina pública, o governo procurou inovar os procedimentos administrativos. Para isso, procurou estimular o desenvolvimento de ações integradas locais e regionais, entre as diferentes secretarias municipais. Criou canais de participação direta, através da abertura aos diferentes segmentos e representações populares nas discussões das políticas públicas municipais. (p.34) Para facilitar a participação social, foram criados vários Conselhos Populares, especialmente na área da saúde, educação, bem-estar social, cultura e habitação.(....) Essas representações civis e populares ganharam embasamento legal com a promulgação da Lei Orgânica do Município que sancionada em 5/4/1990, aprofundou o processo de democratização desencadeado na vida da cidade, regulamentando a participação direta dos cidadãos comuns nas decisões da prefeitura (TELESI JUNIOR 1998, p.36).

Os resultados das entrevistas realizadas por TELESI JUNIOR (1998, p.153) revelam que houve naquela administração uma tendência predominante, especialmente no segmento dos funcionários, de reconhecer "o interesse do governo no desenvolvimento de consciências críticas, com estímulo ao exercício da criatividade e da cidadania, no alargamento da base quantitativa de cidadãos e movimentos sociais envolvidos com a questão saúde". $\mathrm{Na}$ opinião dos dirigentes entrevistados por esse pesquisador, 
houve um grande avanço nos mecanismos de participação popular, com a implantação dos conselhos e comissões gestoras tripartires embora, os funcionários públicos tivessem mais dificuldades para organizaremse e, consequentemente, tiveram uma participação pouco expressiva nos conselhos de gestão (o destaque é nosso) (p.146).

Por outro lado, o processo de implantação das Comissões Gestoras nas Unidades de Saúde não ocorreu com a mesma intensidade nas dez ARS's. Com exceção de algumas regiões onde haviam movimentos populares, a implantação das Comissões Gestoras se deu por iniciativa dos próprios dirigentes. "Nos momentos de tomada de decisão, sempre pesou mais o segmento representado pela administração" (TELESI JUNIOR 1998, p.62).

Na pesquisa realizada por BÓGUS (1997),

a interlocução dos movimentos sociais organizados através dos seus representantes continua dificultada, especialmente nos Conselhos Estaduais e Municipais de Saúde, por prevalecer uma tradição política autoritária e pelo fato da população da maioria dos municípios brasileiros não ter acesso a informações básicas sobre a lógica de funcionamento dos serviços de saúde e sobre as possibilidades de mudança nas propostas de melhoria de condições de vida e saúde ( p.12).

As práticas desse governo municipal enfatisaram a participação da população no diagnóstico de necessidades de saúde, inclusive,

através de oficinas de trabalho (territorialização em saúde, sistema de informação e desenho de operações para o enfrentamento dos principais problemas de saúde) nos territórios de abrangência do nível local. Muitas delas contaram com a presença de três segmentos - administração, funcionários e cidadãos/usuários - visando à adoção de compromissos e responsabilidades comuns frente aos problemas encontrados(....) A impressão é que esse processo teve um caráter pedagógico amplo, (o destaque é nosso) que reforçou a consciência política, especialmente dos funcionários mais simples e dos cidadãos comuns, que se tornaram mais próximos, em função dos problemas e interesses levantados nas oficinas de trabalho (TELESI JUNIOR 1998, p.159).

Acreditamos que todo o processo representou avanços em relação ao modo de pensar as práticas de saúde, e contribuiu para a criação de novos sujeitos coletivos(....) Portanto, sujeitos coletivos foram criados pelo conjunto dos movimentos sociais, e pela política de saúde que se desenvolveu durante o governo Luiza Erundina (TELESI JUNIOR 1998, p.160). 


\subsection{O Centro de Formação dos Trabalhadores de Saúde como espaço institucional de mudança}

Para compreender o espaço que o CEFOR ocupou na qualificação das atendentes através do PLE é preciso reconhecer que a formação de pessoal auxiliar de saúde pelas próprias instituições de saúde constitui, no Brasil, uma tradição de muitos anos. Desde o início, essa iniciativa buscou atender às necessidades de imediata admissão ao serviço sem, no entanto, conseguir superar as dificuldades decorrentes do sistema de ensino que não conduzia à profissionalização em quantidade suficiente e, de acordo com as expectativas das instituições de saúde. Não existia adequação entre a prática a ser desenvolvida nos serviços de saúde e o processo de formação era estabelecido, prioritariamente, através de práticas em laboratórios e aulas expositivas. Além disso, as capacitações desenvolvidas a título de treinamento não dispunham de mecanismos que, junto ao sistema de ensino, garantissem o fornecimento de certificados de profissionalização (MINISTÉRIO DA SAÚDE, 1982).

A proposta de criação de instituições do setor saúde que, atendendo às exigências e normas dos órgãos competentes do setor de educação, pudessem viabilizar a formação de trabalhadores da saúde, empregados no setor e que não tivessem passado por escolarização geral e específica, teve origem na década de 70 , com o Programa de Preparação Estratégia de Pessoal de Saúde. Este Programa contribuiu na implementação dos Centros ou Núcleos de Desenvolvimento de Recursos Humanos nas Secretarias de Saúde dos Estados. Havia uma indiscutível necessidade de reformular os processos educativos e a abordagem pedagógica, procurando uma efetiva integração com a prática em serviço:

\footnotetext{
Tornara-se indispensável que os setores de saúde e educação estabelecessem diretrizes claras, no âmbito federal, para a formação de pessoal auxiliar e experimentassem conjuntamente, numa nova metodologia de capacitação nos estados, preferencialmente voltada para o atendimento das necessidades de recursos humanos da rede de serviços básicos de saúde (Ministério da Saúde 1982, p.5).
}

O Programa de Formação de Pessoal de Níveis Elementar e Médio para os Serviços de Saúde, criado em 1981, estabeleceu então como um dos seus objetivos 
específicos, a implantação de Centro(s) Formador(es) ou Escola(s) Técnica(s) de Saúde.

Nesse programa de formação de pessoal, o Centro Formador de Recursos Humanos para a saúde foi projetado para exercer uma função administrativa, através do registro do histórico escolar dos alunos indicado pelas avaliações de desempenho e indispensáveis para a emissão de certificados de profissionalização, além de apoiar pedagogicamente a ação dos instrutores nos momentos de concentração e nos momentos de dispersão nas unidades de saúde. Foi proposto para diferenciar-se estruturalmente de uma escola convencional, uma vez que seu campo de ensino não é a sala de aula, mas as unidades de saúde em que ensino e serviço acontecem de modo integrado (MINISTÉRIO DA SAÚDE 1983, p.8).

Finalmente, atribuiu-se ao Centro Formador funções relacionadas à reprodução de material didático e manutenção de uma biblioteca, atendendo às necessidades e demandas dos cursos oferecidos (MINISTÉRIO DA SAÚDE 1983; VIEIRA e SCUCATO 1988).

No ano de 1986, a Secretaria de Estado da Saúde do Estado de São Paulo propôs a autorização de funcionamento dos Centros de Formação de Recursos Humanos para a área de saúde junto às Escolas de Auxiliar de Enfermagem de Franco da Rocha, Assis e Pariquera-Açú. A partir daí, outros centros surgiram em diversas cidades do interior do Estado (SECRETARIA DE ESTADO DA SAÚDE $\mathrm{s} / \mathrm{d})$.

No município de São Paulo, a gestão da prefeita Luiza Erundina, em sintonia com as aspirações dos movimentos sociais e de saúde, e de comum acordo com as deliberações da VIII Conferência Nacional de Saúde, reconheceu a profissionalização dos trabalhadores de saúde como uma de suas tarefas prioritárias. Assim, em 30 de março de 1990, através do Decreto Municipal no 28.625/90, foi criado o Centro de Formação dos Trabalhadores de Saúde - CEFOR, vinculado ao Centro de Recursos Humanos da Secretaria Municipal da Saúde (D.O.M. 31.03.90).

O CEFOR estabeleceu-se, tendo como finalidade propiciar a formação e o aprimoramento dos trabalhadores da área da saúde através de: 
- cursos regulares ou supletivos $^{9}$ de qualificação profissional em nível de $1^{\circ}$ e $2^{\circ}$ graus $^{10}$

- cursos de especialização e aprimoramento e,

- produção e difusão de materiais de apoio às ações de desenvolvimento e formação de trabalhadores da saúde.

Assim que ficou definida a sua implantação, foi também escolhida uma diretoria mínima, que pudesse operacionalizar as primeiras deliberações e viabilizar a gerência dessa nova unidade da SMS. Na época, havia um entendimento que o papel do CEFOR seria o de, prioritariamente, desenvolver a formação do pessoal de nível médio e elementar porém, sem se restringir a essa função. À medida que a SMS foi se estruturando, através das Administrações Regionais e dos Distritos de Saúde, novas e importantes demandas foram criadas.

O CEFOR passou a consolidar-se como centro articulador das ações de desenvolvimento de recursos humanos, integrando as áreas de formação, seleção, administração e desenvolvimento. Ficaram sob sua responsabilidade a capacitação de profissionais para o desenvolvimento do projeto de formação e a capacitação de gerentes e centenas de técnicos da equipe de saúde através de cursos de aprimoramento e de especialização em parceria com a Universidade de São Paulo.

Sob seu comando, realizaram-se oficinas que promoveram a apreensão de novas tecnologias em saúde rumo ao novo modelo de atenção implantado, seminários, encontros municipais, bem como a produção e a divulgação de materiais didáticos e técnico-científicos de apoio a esses eventos tais como apostilas, vídeos, textos, cadernos, cartilhas, relatórios entre outros.

Houve modificação da estrutura administrativa inicial, transformando-a em uma estrutura matricial, constituída por 4 núcleos técnicos, que passaram a desenvolver suas ações através de projetos, cujas coordenações poderiam estabelecer parcerias externas à rede de saúde municipal.

Aos núcleos do CEFOR, cabiam as seguintes ações:

\footnotetext{
${ }^{9}$ Ensino ou curso supletivo é o processo de formação de adolescentes e adultos que não tiveram sua escolaridade regular em idade própria. Para regulamentar o ensino supletivo, o Conselho Federal de Educação - CFE - aprovou o Parecer no 699/72 (SILVA 1992, p.9).

${ }^{10}$ De acordo com a Lei de Diretrizes e Bases da Educação Nacional - LDB no 5692/71, a escolarização em nível de $1^{\circ}$ e $2^{\circ}$ graus correspondem, respectivamente, às oito séries do ensino básico, e às três séries do nível médio.
} 
I. Núcleo de Formação: coordenação das atividades de formação de pessoal de nível médio e elementar, através de qualificação profissional, autorizada pelo Conselho Estadual de Educação, e da formação geral, através de projeto de ensino supletivo, desenvolvido em conjunto com a Secretaria Municipal de Educação;

II Núcleo de Desenvolvimento: apoio às atividades de desenvolvimento técnico e gerencial dos serviços da SMS, através de atividades de educação permanente subsidiando a sua realização pelo nível local, buscando para tanto, parceria com universidades e outras instituiçõos públicas;

III Núcleo de Multimeios: organização da biblioteca, videoteca e do Centro de Documentação, além da produção, edição e difusão de materiais de apoio gráfico e audiovisual;

IV. Núcleo do Conselho de Ensino: desenvolvimento de atividades de formação, em serviço, de estudantes e profissionais não pertencentes ao quadro permanente da SMS, através de acordos de cooperação e/ou programas próprios, como residência e estágios. Atualmente, este Conselho e suas atividades não pertencem à administração do CEFOR.

\subsection{O Projeto Larga Escala como estratégia de qualificação de pessoal de nível médio}

Como vimos, no contexto social e político do final da década de 70 e início dos anos 80, caracterizado pela política de extensão da cobertura de serviços de saúde, pela organização dominante da assistência médica privatista, financiada pelo setor público de saúde, e pelo enorme contingente de pessoal leigo prestando assistência à saúde da população, foi assinado, em 1981, um acordo interministerial comprometido com a qualificação profissional dos trabalhadores já incorporados pelos serviços de saúde e também, com a capacitação pedagógica de técnicos de nível superior da área da saúde, denominado Programa de Formação de Pessoal em Larga Escala.

Diferentemente das experiências anteriores desenvolvidas pelas instituições de saúde com vistas a qualificação dos trabalhadores rescém-admitidos, o Projeto Larga Escala não se caracterizou como um mero processo de treinamento. Consistiu, 
efetivamente, na formação de um grande número de trabalhadores que, de forma inédita, não necessitou de afastamento do serviço, e que utilizou, como corpo docente, os próprios profissionais dos serviços na qualidade de instrutores/supervisores.

Quatro foram os princípios fundamentais que contribuíram para a definição do perfil próprio desse programa:

- Integração ensino-trabalho através da formação em serviço;

- Sistematização de um currículo de ensino-aprendizagem que integraliza a formação profissional em vistas de alcançar um perfil de atribuições, com estruturação de conteúdos e planejamento do trabalho pedagógico e com avaliação sistemática no processo;

- Legitimação do processo através de articulações com o sistema formal de ensino, por meio da via supletiva (Lei 5692/71 e Pareceres 853/71 e 540/77 do CFE), possibilitando a concessão de diplomas oficialmente reconhecidos para aqueles que alcancem um desempenho profissional adequado e complementado com os requisitos da educação básica;

- Busca da capacitação técnica indissociavelmente unida ao processo de reflexão crítica, tanto dos fundamentos teóricos, como dos processos sociais envolvidos (MINISTÉRIO DA SAÚDE 1983, p.4-5).

Eram objetivos deste Programa:

Geral:

- Qualificar e habilitar, por via supletiva, com avaliação no processo, pessoal de níveis médio e elementar engajado na força de trabalho ou em processo de admissão.

Específicos:

- Validar as modalidades de ensino promovidas pelas instituições de saúde, com vistas à valorização e ascensão dos profissionais, importando em melhoria de seus níveis de renda.

- Implantar Centros Formadores, que sirvam de base administrativa e pedagógica para a dinamização do processo de formação de recursos humanos nas múltiplas áreas profissionais do setor saúde. 
- Testar novas metodologias de qualificação profissional, tendo como suporte o treinamento em serviço e a utilização, como docentes, do pessoal vinculado à prestação de serviços básicos de saúde.

- Planejar, implantar e desenvolver um sistema de seleção, reprodução e distribuição de material didático, que atenda às necessidades dos treinandos e às peculiaridades do processo ensino-aprendizagem com treinamento em serviço (MINISTÉRIO DA SAÚDE 1983, p.7).

O projeto de formação propunha-se a contemplar no mesmo espaço educativo, três elementos essenciais: o ensino supletivo, o treinamento em serviço e o reconhecimento da habilitação profissional pelo sistema educacional (MINISTÉRIO DA SAÚDE 1983, p.5-6).

A sua realização implicou a assunção de responsabilidades multiinstitucionais e multi-setoriais, mediante a articulação de programas e atividades desenvolvidas pelo Ministério da Educação e Cultura, através das Secretarias Estaduais de Educação, pelo Ministério da Saúde e Secretarias Estaduais da Saúde. As Secretarias de Educação e Saúde participaram ativamente da implantação de Centros Formadores em seus aspectos pedagógicos, técnicos e administrativos, além de promoverem a supervisão e a avaliação de todo o processo. Aos Conselhos Estaduais de Educação coube a apreciação das categorias de formação indicadas pelo Larga Escala. A rede básica constituiu, efetivamente, o campo de educação levando a termo a integração ensino-serviço (MINISTÉRIO DA SAÚDE 1983, p.9-11).

\footnotetext{
O Projeto "Larga Escala" visa a uma integral formação profissionalizante dos adultos engajados na força de trabalho do setor saúde.(....) Entende-se por "Formação" ou educação profissionalizante a apropriação e pleno domínio de conhecimentos e habilidades através da associação teoria/reflexão/prática como um processo que se propõe a: 1) cultivar metodicamente a inteligência; 2) promover a reflexão coletiva sobre a comunidade; 3) estimular generalizações apoiadas em diferentes fontes de informação; 4) propiciar aos educandos a reformulação de suas representações iniciais para assumirem a transformação metódica de sua prática e de seu meio (MINISTÉRIO DA SAÚDE 1983, p.1).
}

A escolha da metodologia desse processo de capacitação foi um aspecto fundamental. Assim sendo, para que se propiciasse, de fato, o desenvolvimento das potencialidades do trabalhador, como cidadão e profissional, com autonomia de pensamento e uma prática crítica e criativa, alguns pressupostos didáticopedagógicos deveriam ser privilegiados: 
- O profissional a ser capacitado deve ser considerado sujeito e não apenas objeto do processo e, como tal, seus conhecimentos, suas experiências, seus problemas e anseios, passam a constituir ponto de partida do processo de ensino/aprendizagem;

- A definição dos objetivos das atividades de capacitação e a seleção dos conteúdos programáticos devem guardar uma relação direta com os problemas anteriores e ulteriores vivenciados pelos treinandos, com o intuito de conferir-lhes relevância dentro do seu universo e permitir assim uma identificação ou compromisso com o assunto, área ou problema em estudo;

- Considerando-se que a aquisição de conhecimentos, ou a aprendizagem, resulta da interação do sujeito com o objeto do conhecimento, na tentativa de apreendê-lo e intervir sobre ele, a prática em situação real deve ser considerada como a situação de ensino/aprendizagem ideal e desejável;

- Como se deseja desenvolver a atitude crítica do profissional que está sendo formado, diante da problemática de saúde que enfrenta, a discussão desses problemas, de pontos de vista diversos e divergentes, passa a ser uma condição para a sua efetivação. Assim, o trabalho de grupo, como experiência de ensino/aprendizagem, deve estar sempre presente e tornarse regra como instrumento de superação de conflitos, divergências e das dificuldades de compreensão dos fatos;

- A fim de que as experiências de aprendizagem alcancem efeito cumulativo, elas devem ser organizadas de modo a se reforçarem mutuamente. Assim, a exercitação dos principais elementos, a repetição, o desenvolvimento progressivo dos conhecimentos e habilidades, é baseada na experiência precedente, ampliando e aprofundando o conteúdo, favorecendo a integração e resultando em mudanças lentas e cumulativas na formas de pensar, em atitudes e no desenvolvimento de interesses (MINISTÉRIO DA SAÚDE 1983, p10-2.)

A avaliação deveria ser entendida como um processo a ser desenvolvido em todos os momentos da atividade pedagógica, como um mecanismo permanente de reflexão sobre o que está ocorrendo com o aprendiz, com o instrutor, com o programa, com o grupo, oferecendo elementos para as reorientações necessárias (MINISTÉRIO DA SAÚDE 1982, p.12-4).

A proposta pedagógica pressupunha uma capacitação de Instrutores/Supervisores, condição básica para o desempenho da função docente. Essa capacitação pedagógica concretizou-se num curso organizado por profissionais do Ministério da Saúde e pela OPAS, destinado aos técnicos da equipe de saúde envolvidos nos projetos de formação do pessoal auxiliar, com carga horária de 80h e conteúdo constituído por textos e exercícios a respeito das características das propostas pedagógicas utilizadas no ensino formal e nos serviços, esquemas de assimilação, características do processo de aprender. 
A partir dessa capacitação e do envolvimento desses profissionais no processo de formação, outras capacitações técnicas foram identificadas como necessárias, uma vez que, "a prática nos serviços de saúde na condição de supervisores, vinha se distanciando de aspetos técnicos específicos implicando em falta de domínio de conhecimentos e habilidades dessa mesma prática" (SANTOS e SOUZA 1989, p.63).

Considerando essa realidade, SANTOS e SOUZA (1989, p.64) propuseram a organização de programas de educação continuada para os profissionais de nível superior nas várias áreas do setor saúde, a fim de se evitar "a institucionalização da dicotomia entre instrutores (docentes) e prestadores de serviços o que inviabiliza a própria proposta metodológica de integração ensino/serviço do projeto Larga Escala. Tratava-se, em síntese, da concepção integral da prática profissional de nível superior articulada coletiva e especificamente para a consecução dos objetivos da Reforma Sanitária”.

\begin{abstract}
Assim, o próprio processo de capacitação, realizado mediante o princípio da integração ensino/serviço, de forma descentralizada, englobando atividades na sede das regionais e nas unidades locais, deve ser encarado como meio de organização interna das unidades. Deve-se compreender que existe uma influência recíproca entre, de um lado, a organização e descentralização operacional da rede, e, de outro, as atividades de desenvolvimento de recursos humanos baseado na metodologia de integração ensino/aprendizagem (MINISTÉRIO DA SAÚDE 1982, p.15)
\end{abstract}

Havia a expectativa que o Larga Escala produzisse, simultaneamente, alguns efeitos gerais, como a renovação dos aspectos pedagógicos da supervisão nas instituições de saúde associada a um maior ajuste na organização dos serviços (MINISTÉRIO DA SAÚDE 1983, p.15).

"Durante o desenvolvimento da capacitação dos profissionais, os serviços [deveriam] se organizar de forma concomitante. Ao mesmo tempo em que se [criavam] situações que facilitavam a aprendizagem, efetivava-se a melhoria da qualidade da assistência prestada" (VIEIRA e SCUCATO 1988, p.44).

O Larga Escala foi trazido para São Paulo, em 1985, através do Programa Metropolitano de Saúde e vinculado à Secretaria de Saúde do Estado (CORVINO1991). Nessa época, técnicos do Ministério da Saúde e da OPAS desenvolveram capacitações pedagógicas dos Instrutores Supervisores que 
posteriormente iniciaram o processo de formação de atendentes de consultório dentário - ACD , Técnico de Higiene Dental - THD, e do Auxiliar de Enfermagem, a partir do ano seguinte, 1986.

No âmbito municipal, o PLE foi considerado prioritário pela política de recursos humanos da Secretaria Municipal de Saúde, e divulgado em documentos oficiais, ao longo do ano de 1989. De acordo com as diretrizes estabelecidas naquela gestão municipal de participação e descentralização, foram realizados dois grandes seminários envolvendo os atendentes de enfermagem, categoria prioritária para o processo de profissionalização, e os enfermeiros, profissionais da área específica de formação, além de diretores dos Distritos de Saúde e técnicos da área de recursos humanos, sindicatos e outras entidades.

Os seminários foram palco de amplos debates para esclarecimentos da proposta de formação a ser implantada, os critérios de seleção das turmas, da escolaridade básica, entre outros aspectos. Definiu-se que os cursos seriam realizados de forma descentralizada junto aos Distritos de Saúde, com um número de turmas correspondente à disponibilidade de instrutores capacitados para o processo e no horário de trabalho dos servidores. As turmas assim estruturadas deveriam ter um local definido para os momentos de concentração (teorização) do curso, preferencialmente próximo ao local de trabalho dos servidores, o que, num segundo momento, tornar-se-ia o próprio local da dispersão (prática) (SECRETARIA MUNICIPAL DA SAÚDE, 1989).

Essa modalidade de formação profissional objetiva

\begin{abstract}
capacitar os indivíduos tecnicamente e ao mesmo tempo desenvolver a reflexão crítica tanto em relação ao conteúdo técnico como ao contexto social onde seu trabalho é desenvolvido. O conteúdo programático deveria ser compatível com a realidade epidemiológica e a organização dos serviços de saúde da região Busca-se a construção da consciência sanitária e o compromisso com o trabalho gerando um determinado grau de solidariedade. O reconhecimento do objeto de trabalho na área de saúde, o indivíduo e a coletividade, faria a distinção desse trabalho e o da área de produção de bens, o que resultaria no resgate da dimensão humana dessa prática, da sua valorização, e do exercício da cidadania, implicando no compromisso dos trabalhadores do setor com o efetivo funcionamento dos serviços públicos de saúde (SECRETARIA MUNICIPAL DA SAÚDE 1989, p.7-8).
\end{abstract}


A fim de cumprir tais objetivos, o Larga Escala deveria utilizar uma metodologia dita problematizadora, que "propicia a participação do aluno, respeitando seu ritmo de aprendizagem, e coloca o monitor e aluno como sujeito e objeto, ao mesmo tempo, no processo ensino-aprendizagem" além, de utilizar as equipes multiprofissionais dos serviços como o elemento formador, devidamente preparado, para viabilizar o processo com esse perfil (SECRETARIA MUNICIAPAL DA SAÚDE 1989, p.7-8).

\subsection{A metodologia problematizadora como eixo de reordenação do processo educativo}

No desenvolvimento deste nosso estudo, optamos por recuperar através de documentos, o ideário do PLE enfocando objetivos, pressupostos e a estratégia metodológica. Por tê-la considerado relevante na condução do processo de formação, vimos necessidade de situar aqui, mais detalhadamente, os pressupostos teóricos dessa metodologia assim como o contexto histórico-social em que foi proposta.

Para tanto, será preciso reconhecer que os educadores, ao classificar as tendências ou opções pedagógicas, o fazem a partir das relações entre a educação e a sociedade. Assim sendo, ao detalhar os aspectos da metodologia problematizadora, verificamos que sua proposição guarda relação com a co-responsabilidade dos profissionais da educação frente a opção de caminhos que possam facilitar o alcance de uma sociedade mais justa (BORDENAVE, 1981).

Mais especificamente, a metodologia problematizadora tem sua gênese em um grande movimento que surge na primeira metade deste século, chamado Escolanovismo ou Escola Nova, cuja manifestação foi mais nítida na América Latina, inicialmente no âmbito de escolas experimentais (SAVIANI, 1997). Nessa nova forma de conduzir a educação, a atitude da escola era a de aceitação incondicional do aluno e de respeito às diferenças. O processo educativo, centrado no aluno, passaria a valorizar os aspectos afetivos, ficando o ensino reduzido à dimensão do saber ser (DONATO s/d).

Os fatos demonstraram que esse tipo de Escola também não cumpriu o objetivo de "tornar aceitos os indivíduos rejeitados"; a flexibilização da disciplina e a 
negligência com a transmissão de conteúdos prejudicou os alunos das camadas populares e acentuou o problema da marginalidade.

Segundo SAVIANI (1997, p.23) surgiram então tentativas de desenvolver uma espécie de "Escola Nova Popular". Seus exemplos mais significativos foram as pedagogias de Freinet e de Paulo Freire, consideradas como progressistas por LIBÂNEO (1982, p. 12) que classificou as tendências pedagógicas, utilizando como critério a posição que adotam em relação às finalidades sociais. $\mathrm{O}$ autor empresta de Synders (1974) o termo 'Progressista' para “designar as tendências que, partindo de uma análise crítica das realidades sociais, sustentam implicitamente as finalidades sócio-políticas da educação" . A pedagogia progressista, numa sociedade capitalista, encontra seu significado como "instrumento de luta dos profissionais da educação ao lado de outras práticas sociais" .

Uma das versões da pedagogia progressista, ainda segundo LIBÂNEO (1982, p.12), é a Libertadora, mais conhecida como pedagogia de Paulo Freire; a segunda seria a Libertária, que reúne os defensores da autogestão pedagógica, tendo sido considerado significativo o trabalho de C.Freinet; a terceira, a dos Conteúdos, que acentua a primazia dos conteúdos no seu confronto com as realidades sociais.

“As versões Libertadora e Libertária têm em comum o anti-autoritarismo, a valorização da experiência vivida como base da relação educativa e a idéia de autogestão pedagógica. Em função disso, dão mais valor ao processo de aprendizagem grupal (participação em discussões, assembléias, votações) do que aos conteúdos de ensino. Como decorrência, a prática educativa somente faz sentido numa prática social junto ao povo, razão pela qual preferem as modalidades de educação popular "não formal"” (LIBÂNEO 1982, p. 12).

A tendência Progressista Libertadora em particular, quando trata da educação em geral, a refere como uma atividade onde professores e alunos, "mediatizados pela realidade que apreendem e da qual extraem o conteúdo de aprendizagem, atingem um nível de consciência dessa mesma realidade a fim de nela atuarem, num sentido de transformação social” (LIBÂNEO 1982, p. 15).

Os conteúdos denominados "temas geradores", são extraídos da problematização da prática de vida dos educandos. O importante não é a transmissão de conteúdos específicos, mas despertar uma nova forma de relação com a experiência vivida. A forma de trabalho educativo é o 
"grupo de discussão". Educador e educandos se posicionam como sujeitos do ato de conhecimento. Admite-se a avaliação da prática vivenciada entre educador educandos no processo de grupo e, às vezes, a autoavaliação feita em termos dos compromissos assumidos com a prática social (LIBÂNEO 1982, p.15).

GADOTTI (1986, p.47 ) ao analisar o trabalho de Paulo Freire, reitera que “(....) a educação não revoluciona a sociedade, mas é verdade que a educação também faz parte da sociedade, portanto, nela também existe o espaço político no qual se travam lutas políticas. Há uma unidade entre as lutas sociais e as lutas pedagógicas". Considera que, "depois de Paulo Freire, ninguém mais pode ignorar que a educação é sempre um ato político".

Realizando-se uma análise das possibilidades de atuação na área de formação de pessoal nas organizações, é possível reconhecer duas tendências opostas: "uma, onde as ações de formação não têm poder de transformação das pessoas, das relações de trabalho, nem da realidade profissional; uma outra, onde essas ações podem vir a representar um espaço político, embora limitado e de importância relativa, na superação de contradições internas e externas às organizações" ( BÓGUS 1992, p.61).

BÓGUS (1992), quando cita Amaral (1987) no que diz respeito à aplicação dos conceitos de FREIRE à formação de pessoal, "explicita o tipo de projeto político resultante: seria oposto a uma prática domesticadora e teria como objetivo a transformação de funcionários em produtores eficientes, segundo padrões determinados pelos que controlam as decisões nas organizações".

No entanto, o próprio FREIRE “quando indagado a respeito dos programas de formação e desenvolvimento de pessoal, salientou que o "problema principal é político e ideológico, muito mais do que um problema de pedagogia, técnico ou de método de ensino, pois tem a ver com os limites de ação do empregado que apesar de passar por um processo de desenvolvimento com uma visão progressista, não terá condições de atuar de modo transformador já que esse papel, geralmente não é o esperado pela instituição empregadora" (BÓGUS 1992; p.63).

Os profissionais do setor saúde, ao discutirem o desenvolvimento das ações de saúde junto às populações, valorizam a necessidade da utilização de métodos participativos que possam subsidiar a formação de uma consciência sanitária. "Dessa forma, ao analisarmos aqui algumas das características do processo de educação, 
partimos da admissão de que existem dois saberes: o saber técnico e o saber popular““ (PINTO s/d, p. 2). "O desempenho desses técnicos, educadores, comprometidos com o projeto político da Reforma Sanitária representa o abandono de "ações educativas informativas e normativas de preceitos de saúde, [para] se transformarem em provisores de ferramentas pedagógicas de um processo educativo eminentemente crítico" (WESTPHAL e PELICIONI 1991, p.70 ).

Para o alcance de uma consciência sanitária, a contribuição da educação em saúde junto ao pessoal de saúde requer a sua interferência "junto aos órgãos responsáveis por recursos humanos no sentido de fazê-los conhecer a importância social do seu trabalho, as necessidades da população que está atendendo e deixar de reproduzir as relações de poder que vivenciam ou que estão acostumados a presenciar entre profissionais e clientela". Além disso, é necessário o desencadeamento de ações cooperativas e democráticas entre todos os profissionais da equipe de saúde com vistas a uma pratica social comprometida com a causa popular" (WESTPHAL e PELICIONI 1991, p.70-1 ).

Mendes (1985) é citado por CORVINO (1991, p.85) ao discutir a

\begin{abstract}
importância da utilização de métodos que se tornam relevantes para o trabalho quando além de enfocar o contexto técnico, associam o embasamento humanístico e político. Percebe-se uma nítida intenção de superar a fragmentação dos conteúdos e a decantada separação entre teoria e prática, através da ação-reflexão-ação do processo ensinoaprendizagem, com o objetivo de transformar a realidade, a partir de análise das práticas profissionais.
\end{abstract}

CORVINO (1991) advoga a necessidade de

serem mais utilizadas as estratégias que privilegiam o desenvolvimento profissional centrado no próprio processo de trabalho, seja ele da esfera municipal, estadual ou federal, constituindo-se em efetivos centros de excelência ou referência assistencial para o desenvolvimento dos recursos humanos (p. 188).

"As atividades cotidianas devem compor o conteúdo do aprendizado, com seus conflitos, gerados inclusive pela aquisição de conhecimentos mais abrangentes, numa perspectiva de aperfeiçoamento profissional, necessário ao incremento de resolutividade do atendimento às demandas da comunidade" (CORVINO 1991, p.87). 
OLIVEIRA (1996, p. 13), ao discutir o acesso às oportunidades de formação enquanto direito social, amplia a influência desse processo para além dos limites de ajuste de mão de obra e de instrumentalização técnica. A utilização "de estratégias e ações de ensino que fazem do trabalho um espaço de intervenção na sociedade civil, imprimem um movimento de conquista e participação onde o processo ensinoaprendizagem assume caráter mediador e de transformação institucional”.

Visto que, a população alvo do processo de formação do PLE são adultos que, na sua maioria, não tiveram oportunidade de completar a sua escolarização básica na idade estabelecida para isso, entendemos que a escolha da metodologia problematizadora, para compor a estrutura de desenvolvimento do PLE, com os aspectos nucleares da tendência libertária, ofereceram as bases para 0 encaminhamento de uma qualificação dos trabalhadores da saúde na busca da transformação da realidade da situação de saúde e de assistência à saúde. 


\section{O PLANO DA PRÁtiCA: A COMPREENSÃO DOS ENVOLVIDOS NO PROCESSO DA QUALIFICAÇÃO DOS TRABALHADORES DE SAÚDE}

\subsection{A opinião dos coordenadores do nível central}

Respeitando o que foi estabelecido no caminho metodológico desta pesquisa, buscamos dados junto ao nível central da Secretaria Municipal de Saúde representada então, pelo Centro de Formação dos Trabalhadores da Saúde - CEFOR. Nessa oportunidade, foram entrevistados os profissionais que atuaram no período deste estudo como Diretor do Centro de Formação e como Coordenadora do Projeto Larga Escala que, no nosso entender, revelariam particularidades referentes ao objeto desta pesquisa além, do contexto técnico e político mais geral da SMS onde o projeto se inseriu e se desenvolveu.

\subsubsection{Quanto aos princípios e diretrizes do SUS}

Chamou-nos a atenção o valor atribuído às diretrizes descentralização e participação popular na gestão municipal, 1989 - 1992. Como denotam os depoimentos, cujas referências foram inúmeras vezes realizadas, o compromisso daquela administração com a implantação do Sistema Único de Saúde no município de São Paulo, determinou a reorganização dos equipamentos de saúde, além de profundas mudanças nas práticas desenvolvidas neste setor, tais como:

\footnotetext{
A diretriz principal era descentralização e participação popular na gestão.

(....) é descentralizar o poder das Secretarias, todas as secretarias trabalhavam em função disso.

Era investir nas sub prefeituras.

e na saúde isso também foi o que norteou toda a organização do nível central no sentido de dar autonomia pró nível local.

Era assim que se constituiu as $\operatorname{ARS(s),~assim~que~se~constituiu~os~}$ Distritos de saúde.
} 
e criar espaços de participação popular e, no caso da saúde (....) era também de participação do trabalhador nas decisões do serviço. (DEPOIMENTO 1, 1999)

(....) a idéia era, em primeiro lugar, de se fazer a municipalização dos serviços quer dizer... criar um processo de regionalização da cidade que primeiro a dividiu em 10 administrações regionais de saúde - ARS e cada ARS dessa depois se subdividiu num total de 32 distritos de saúde - DS (....)

(....) e uma idéia muito importante de gente do governo era a idéia do poder popular local, a questão de mecanismo de construção de poder local (....)

Então a idéia era descentralizar a cidade de São Paulo e não ser só a saúde que se descentralizaria, mas todas as demais secretarias deveriam se dividir em administrações regionais e criar sub prefeituras ou prefeituras regionais.

(....) o que era mais claro era justamente a perspectiva do controle público, do controle social dos equipamentos de saúde através da construção de conselhos gestores (DEPOIMENTO 2, 1999).

A descentralização da SMS, enquanto diretriz, vinha ao encontro dos interesses políticos mais gerais da reforma sanitária,

de viabilizar o acesso à saúde da população (DEPOIMENTO 1, 1999),

numa perspectiva de universalizar o atendimento da cidade (DEPOIMENTO 2, 1999).

Os depoimentos revelam também que a implantação do SUS no município,

requereu a universalização, a busca de igualdade no atendimento, a equidade quer dizer, fazer do uso da saúde um instrumento de justiça social, de redistribuição de poder, de qualidade de vida, (....) (DEPOIMENTO 2, 1999).

No que diz respeito mais especificamente ao atendimento, os depoimentos enfocaram uma grande preocupação em implantar programas de atenção à saúde sustentados por uma lógica diversa daquela existente, de uma lógica que valorizasse a vigilância epidemiológica.

Partia-se de um princípio que era de trabalhar com a equipe multidisciplinar e buscar uma prática que não fosse centrada no médico, na assistência médica (DEPOIMENTO 1, 1999). 
Nesse sentido, referendam que era preocupação do nível central atingir a integralidade das ações em saúde:

colocar a assistência médica individual não como fim, mas como parte, como um instrumento de uma política mais geral, mais orientada para a saúde coletiva (....) onde as ações curativas individuais tivessem um caráter de certa forma subordinado às características epidemiológicas, das determinações sociais do processo saúde-doença de cada bairro, de cada região...(DEPOIMENTO 2, 1999).

Reconhecemos então, que as diretrizes políticas da SMS estavam comprometidas com as proposições do movimento da Reforma Sanitária. As mudanças implementadas, constituídas em uma rede complexa de decisões, tinham como meta alterar padrões de serviços estabelecidos ao longo dos anos, e caracterizados pelo atendimento médico hospitalar de urgência e por unidades de assistência médica ambulatorial. Almejou-se para isso a modificação de processos de trabalho de tal forma que os determinantes do processo saúde-doença, as condições de maior exposição/risco de adoecer, as condições de acesso da população e a oferta de serviços adequados às suas necessidades fossem explicitados, tendo por objetivo a integralidade das ações mediante a inter-relação de diferentes profissionais, a utilização das ações de atenção à saúde nos diferentes níveis de complexidade e, até mesmo, através da utilização de bens e serviços disponíveis fora dos limites do setor saúde - através de ações de caráter intersetorial.

Assim posto, pudemos reconhecer a importância que a diretriz integralidade alcançou nesta gestão municipal, pois as modificações implantadas nas ações de atenção buscavam atender às necessidades de saúde da população nas suas várias dimensões. Também reconhecemos que a incorporação dessas mudanças exigiu a adoção de práticas democráticas de decisões: os trabalhadores foram ouvidos e envolvidos, a fim de compreender a natureza, a importância e a abrangência do seu trabalho junto à população. Inúmeras foram as oportunidades de participação naquela gestão, com vistas ao exercício do controle social sobre as atividades e os serviços de saúde.

\subsubsection{Quanto à política de recursos humanos}


No contexto de mudanças anteriormente relatado, o entendimento que a SMS tinha a respeito da política de recursos humanos era, necessariamente, diferente das anteriores e estratégica para fazer funcionar o serviço de saúde da forma como ele estava sendo idealizado

que pela própria natureza, tem o seu trabalhador como elemento central (DEPOIMENTO 2, 1999).

Nessa lógica, o recurso humano

deixa de ser visto como mais um 'insumo' e passa a ser visto como um 'sujeito' com necessidades, desejos, direitos, valores, formas de pensar etc (DEPOIMENTO 1, 1999).

A política de RH, então estabelecida, deveria inter-relacionar as

áreas de formação, administração, seleção e concursos que, historicamente, eram desenvolvidas de forma autônoma (DEPOIMENTO 2, 1999).

Buscou-se, então, estruturar a área de RH de tal forma, que esses três segmentos pudessem ter interlocutores em órgãos colegiados de cada uma das 10 ARSs e depois em cada um dos 32 DS.

A área de formação deveria ter um peso muito grande nesta política (DEPOIMENTO 2, 1999).

era como um instrumento, como uma estratégia na busca de construir novas práticas de saúde (DEPOIMENTO 1, 1999).

Podemos assimilar então, que a descentralização política e administrativa da SMS requereu a mesma condição da política de RH para de fato viabilizar as questões gerenciais. Esta política de RH foi planejada para desenvolver-se de forma articulada, integralizada, assentando-se sobre o princípio da valorização do trabalhador, fosse através da remuneração digna, fosse através da capacitação técnica para o trabalho ou ainda, através do incentivo à participação mediante as suas 
representações e em respeito à sua contribuição nas decisões para as mudanças na organização dos serviços.

Parece-nos importante destacar o entendimento sobre o alcance da proposta de formação nesse nível de gerência do PLE. Não havia dúvidas quanto a sua importância no entanto, tanto a direção do CEFOR quanto a coordenação do projeto, tinham clareza de que ela não seria a responsável pelas mudanças esperadas nos serviços mesmo que os currículos dos cursos fossem organizados com este viés

ou seja, para fazer mudanças nos serviços, não poderia ser através da formação de pessoal, mas através de mudanças na própria organização do trabalho (DEPOIMENTO 2, 1999).

SANTANA (1990), ao discutir a formulação de políticas de RH nos serviços de saúde, apresenta como um dos "pontos de partida" a consideração de que "apesar da importância que têm os recursos humanos no contexto da produção/oferta de serviços de saúde, às propostas de intervenção sobre esses recursos não pode ser dada uma potencialidade que elas, isoladamente, não podem ter: modificar os serviços de saúde. Este objetivo exige outras decisões e ações além daquelas dirigidas aos recursos humanos".

Havia uma necessidade imperiosa de reordenar a organização do trabalho, até porque a estrutura existente era uma estrutura médica de urgência e havia um indiscutível interesse de trabalhar numa outra perspectiva.

Existia um fosso entre os hospitais e a rede básica. Era isso que precisava mexer de algum jeito, de unir as coisas... (DEPOIMENTO 2, 1999).

\section{A [área de]}

formação foi vista, inicialmente, como um instrumento no sentido de buscar mudança, de transformar uma prática (DEPOIMENTO 1, 1999).

Mas no nosso discurso, e na nossa discussão com as pessoas, era esse o entendimento. Você tem um projeto de formação em trabalho, que tem que estar costurado com o movimento do próprio trabalho, as mudanças que estão acontecendo no próprio trabalho, e que termina no momento que você formou as pessoas que você pretendia formar (DEPOIMENTO 1, 1999). 
$A$ decisão política sobre a população alvo a ser escolhida para passar pelo processo de formação nos pareceu criteriosa e promotora de justiça uma vez que reconhecia que o pessoal de nível médio e elementar que, tradicionalmente, não era o escolhido para o desenvolvimento de treinamentos e atualizações, seria o pessoal estrategicamente priorizado [ em função de]

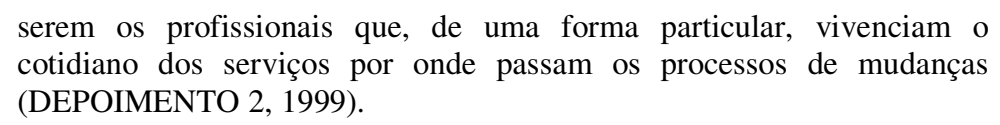

Nossos dados revelam-se coerentes com a discussão apresentada por TELESI JUNIOR (1996) que identificou na opinião dos dirigentes entrevistados o "reconhecimento de que a Secretaria promoveu a equidade ao organizar todo o processo de desenvolvimento dos recursos humanos ( o destaque é nosso) e, na incorporação de novas tecnologias que possibilitaram a resolução de problemas de saúde dos grupos mais desfavorecidos".

Ao analisar então, a política de RH definida pela SMS, podemos reconhecer nela a presença das diretrizes políticas do SUS: a implementação da descentralização, da integralidade, da equidade, e o incentivo e o respeito à participação, na busca da universalidade - contemplando todos os trabalhadores envolvidos - a propósito da melhoria da qualidade da atenção à população.

\subsubsection{Quanto ao Centro de Formação e ao Projeto Larga Escala}

Os depoimentos foram enfáticos ao contextualizar o PLE como um elemento imprescindível da política de RH da SMS. Num levantamento do quadro de pessoal realizado em 1989, constatou-se que o pessoal de nível médio e elementar constituía $50 \%$ dos trabalhadores dessa Secretaria. Ao descentralizar as políticas e a gerência, responsabilizou-se os níveis regionais para a profissionalização desse pessoal. Porém, optou-se por um dado processo de formação que viabilizasse o projeto político mais geral de implantação do SUS. 
A definição pelo projeto de formação de pessoal de nível médio, que pudesse servir a um contexto bastante diversificado de mudanças também determinou a escolha de um princípio pedagógico - a prática profissional -coerente com este processo e com as características do público com o qual se deveria atuar. Segundo os dados obtidos, discussões com pessoas fundamentais como Paulo Freire, com estudiosos de teóricos como Gramsci, além das próprias autoras do PLE, Isabel dos Santos e Ena Galvão, vieram a confirmar o acerto dessa decisão.

Autores como CORVINO (1991); PAIM (1994), também defendem o desenvolvimento de propostas de capacitação de trabalhadores do setor saúde, que reconheçam o trabalho como princípio pedagógico.

A direção do CEFOR respeitou a decisão da coordenação do PLE de manter uma autonomia frente ao projeto original que permitisse considerar os diferentes contextos locais, possibilitando, dessa forma, criar e modificar o projeto para servir às especificidades de cada realidade.

TORRES (1994) reconhece que o "desenvolvimento das qualificações profissionais e da consciência crítica dos trabalhadores, identifica-os com a fundamental opção político-pedagógica de promover uma qualificação emancipatória, onde o sujeito qualificará o seu trabalho, em oposição à 'qualificação para o trabalho"” (p.151).

Dessa forma, assumiu-se que o pressuposto de profissionalizar trabalhadores adultos no ambiente de trabalho - cenário de distintos processos de mudanças constituir-se-ia numa pedagogia facilitadora do desenvolvimento de "sujeitos críticos" que tivessem por referência as realidades locais de saúde e reconhecessem a importância da participação (própria e dos demais usuários dos serviços) na defesa dos seus interesses:

a idéia era que os usuários tivessem ampla maioria e que a unidade dos trabalhadores de saúde com os usuários enquanto unidade potencialmente estratégica, pudesse ser uma ampla maioria, que forçasse as políticas públicas num certo rumo (DEPOIMENTO 2, 1999).

Para PAIM (1994), tal decisão revela a responsabilidade dos envolvidos com as tarefas da formação e desenvolvimento de RH para o setor saúde, na identificação 
de oportunidades, do exercício da criatividade, na produção de fatos sociais que "contribuam para a construção de uma sociedade menos hostil para seus cidadãos".

Pareceu-nos importante resgatar as informações obtidas com o diretor do CEFOR com relação aos esforços empreendidos por essa instituição junto à Secretaria Municipal de Educação, para que esta autorizasse o Centro de Formação a certificar os cursos de formação desenvolvidos. Até aquele momento, havia um entendimento de que "formação" era atribuição da educação e, não poderia ser estendida para além dessa Secretaria. Muitos foram os esforços empreendidos, até que o CEFOR se vinculasse a uma Escola da rede municipal de ensino e assim, nessa condição, pudesse certificar os cursos de formação.

Podemos analisar então, que a SMS foi vitoriosa ao conseguir receber a delegação do setor educacional para a certificação dos cursos, competência até então exclusiva daquele setor. Também foi relevante nesse contexto, o projeto Supletivo desenvolvido pelo CEFOR. Uma das características da população a ser qualificada era a sua baixa escolaridade o que determinou o desenvolvimento de um projeto de escolarização dos alunos, através da via supletiva, em convênio com a SME. O primeiro projeto desenvolvido foi para a SMS e depois foi se estendendo para outras Secretarias.

Essas características identificadas no contingente de servidores da SMS estavam em absoluta concordância com as características reveladas por diferentes autores: MÉDICI 1987; CORVINO 1991; PAIM 1994; ASSOCIAÇÃO BRASILEIRA DE ENFERMAGEM 1999.

A direção do CEFOR teve um entendimento de que esses dois projetos, o PLE e o Supletivo, foram os responsáveis para dar a este Centro de formação a visibilidade e a credibilidade necessárias frente aos demais projetos gerenciais que os sucederam;

eram cursos longos, muita gente em formação, muitos técnicos envolvidos, grandes eventos, grandes formaturas, condições que deram sustentação política ao CEFOR frente aos projetos seguintes.

\subsubsection{Quanto ao Centro de Formação dos Trabalhadores da Saúde}


A decisão de criar o CEFOR trouxe a necessidade de se pensar numa estrutura física adequada aos seus propósitos. Deveria ser uma estrutura de apoio técnico, pedagógico, que utilizasse o próprio quadro de pessoal da rede de saúde municipal para o desenvolvimento dos seus projetos. Houve um confronto desse entendimento com a proposta defendida pelos técnicos dos Ministérios - a criação de Escolas Técnicas de Saúde no país. Para a direção do CEFOR, considerando entre outros fatores a diretriz da integralidade do SUS, seria um equívoco da equipe reduzir a atuação deste Centro apenas à formação do pessoal de nível médio e mais particularmente, à enfermagem, na sua condição de maior contingente de trabalhadores. A mudança que se buscava extrapolava a questão da formação. Por isso, desde o início, incorporou-se a discussão dos concursos, a ampliação da equipe de saúde através da contratação de diversos profissionais, a reorganização dos serviços, a adequação dos programas de atenção à saúde, a capacitação de gerentes, a especialização de técnicos etc.

(....) além das tarefas de formação no 'stricto sensu', de dar o diploma de auxiliar, de técnico, disso, daquilo, ele deveria mexer também com a questão de desenvolvimento de pessoal, quer dizer, de oferecer as atividades que a gente fazia...(DEPOIMENTO 2, 1999).

Os depoimentos nortearam ainda que, quando se buscou os referenciais teóricos que deram sustentação ao Centro de Formação, foi necessário retornar ao final da década de 70 e identificar os fatos importantes daquele período e as articulações sociais realizadas. Assim, recuperou-se três grandes vertentes que deram sustentação a um processo de ruptura e reordenação social: o surgimento de um "novo sindicalismo", os movimentos sociais urbanos e a articulação da Igreja através dos movimentos eclesiais de base e a Teologia da Libertação.

Estas matrizes propiciaram ao setor saúde algumas aproximações e articulações que reverteram em teorias e propostas de reorganização dos processos de trabalho em saúde: surgem os programas de atenção à saúde: saúde do trabalhador, saúde da mulher, saúde da criança, a luta antimanicomial. Também contribuíram alguns sanitaristas vinculados ao Departamento de Medicina Preventiva da 
Faculdade de Medicina da Universidade de São Paulo, que passaram a discutir o papel da saúde coletiva, seu objeto de trabalho, seus instrumentos, seus conceitos.

De acordo com os relatos, estas foram as fontes que contextualizaram importantes movimentos sociais e sujeitos sociais, que trouxeram para dentro da Secretaria Municipal da Saúde e, particularmente para dentro do CEFOR, as suas propostas de reorganização dos serviços de saúde municipais e de sustentação teórica para os cursos de formação.

O Centro de Formação ao finalizar os levantamentos dos trabalhadores interessados na profissionalização, procurou realizar as capacitações pedagógicas dos profissionais de saúde que desenvolveriam os cursos de formação, inicialmente as enfermeiras e os dentistas. Estas capacitações consistiam em cursos de 80 horas, destinados a fazer uma primeira aproximação teórica/metodológica com aqueles que seriam os Instrutores dos cursos de formação. Ocorreram diversos cursos coordenados pelo Cefor, num primeiro momento, nas dependências do próprio Centro de Formação e, num segundo momento, nas Administrações Regionais de Saúde que pudessem sediá-los e, em parceria com as equipes de recursos humanos daqueles locais.

Constatamos, com a incorporação de diferentes profissionais de saúde na rede municipal mediante os concursos públicos, que as próprias capacitações abarcaram outras categorias profissionais tais como as educadoras de saúde pública, as psicólogas, as médicas, as assistentes sociais, as farmacêuticas, as fonoaudiólogas, entre outras. Havia uma preocupação da Coordenação do PLE de não isolar o projeto de formação das demais atividades relativas a recursos humanos: buscou-se estimular que os coordenadores da formação participassem das demais atividades de RH do seu nível local além, de valorizar a composição multidisciplinar das equipes de coordenação e desenvolvimento dos cursos Havia um entendimento de que a formação deveria estar muito próxima da dinâmica do serviço.

Eles tinham que necessariamente envolver os educadores, psicólogos, assistentes sociais, médicos, porque eles precisariam disso, desses profissionais e isso é que ia dar uma cara para o curso voltada para o trabalho, que constituía a equipe multiprofissional (DEPOIMENTO 1, 1999).

A direção do CEFOR revelou que o seu empenho foi muito grande no sentido de manter a integração das questões relativas a $\mathrm{RH}$, o que veio posteriormente a 
determinar a realização das reuniões das equipes de RH no Centro de formação, onde seriam pontos de pauta todas as questões que envolvessem recursos humanos (formação e desenvolvimento de pessoal). Além dessas reuniões gerais de RH, o CEFOR também promovia as reuniões com os Coordenadores dos cursos de formação (profissionais que viabilizavam o desenvolvimento dos cursos em diferentes áreas) além das reuniões por área específica. (enfermagem, odontologia e posteriormente a farmácia).

A realidade nos mostrou que cada local, cada curso, desenvolveu-se como um sistema, com as características decorrentes da articulação de todos estes fatores, o entendimento da proposta, o envolvimento dos profissionais, as questões pessoais, as questões estruturais relativas ao serviço, e à dinâmica de cada região/local/curso/alunos/instrutores.

O CEFOR constituiu-se num legítimo palco articulador de todos esses eventos tanto na área de formação, quanto na área de desenvolvimento técnico e gerencial. Acreditamos que a política de RH teve esta possibilidade de articular e, fundamentalmente, de viabilizar as políticas da SMS porque desenvolveu-se mediante a descentralização política e administrativa, esteve assentada sobre duas diretrizes básicas: a integralidade e a participação com vistas a equidade e a universalização.

\subsection{A opinião dos coordenadores do nível regional}

Num momento posterior, em continuidade a nossa pesquisa de campo, passamos a colher dados junto aos profissionais que estiveram envolvidos diretamente com o desenvolvimento dos cursos e, também com outros, que de alguma forma contribuíram para a sua realização.

A primeira profissional entrevistada nessa ocasião, prestou serviço na área hospitalar, na equipe de recursos humanos e, passou então, a coordenar o curso de formação de auxiliar de enfermagem do DS. O seu envolvimento com o curso deu-se de uma forma bastante incisiva, logo após a capacitação pedagógica. Até aquele 
momento, essa profissional nunca havia se dedicado ao ensino, declarando ter se interessado pela metodologia do curso e ter decidido "assumir" a formação dos atendentes que prestavam serviço naquele hospital. À medida que foi desenvolvendo as suas funções e avaliando os resultados, o seu envolvimento tornou-se significativamente maior,

deixou de ser só um compromisso com o trabalho, mas um envolvimento pessoal mesmo, cabeça, corpo e alma, (DEPOIMENTO 3,1999).

Esse tipo de "adesão" ao processo de formação também foi referido por TORRES (1994) ao confirmar que "foi o fenômeno metodológico, o processo ensino-aprendizagem por ele preconizado,[o PLE] o que efetivamente atraiu muitos de nós", situação essa, também confirmada por CORTEZ (1993) citada por TORRES (1994, p.16) que disse que ficou "fascinada pela proposta pedagógica ... mágica, mas que não tinha à época a compreensão daquela dimensão" (a dimensão política).

A entrevistada seguinte pertencia à mesma região de saúde que a anterior. Também trabalhava na unidade hospitalar, teve um primeiro contato com o projeto através de um curso de sensibilização desenvolvido sob coordenação do CEFOR na sede da ARS, foi encaminhada para fazer a capacitação pedagógica, fez em seguida uma capacitação técnica e decidiu dedicar-se ao PLE, dispensando, inclusive, uma proposta de encarregatura de serviço que lhe haviam feito na mesma ocasião. De acordo com o seu relato, a opção pelo projeto foi uma "coisa traumática" porque a sua chefia tinha uma outra expectativa para o seu desenvolvimento profissional e, apesar disto, o seu sentimento é de ter feito a escolha certa:

era um trabalho que dava muito prazer pra gente, a gente dava muita risada, brincava muito! (....) eu nunca trabalhei num lugar assim de uma forma tão prazerosa como nessa época (DEPOIMENTO 4, 1999).

A entrevistada do DEPOIMENTO 5, também prestava serviço na área assistencial hospitalar e, foi convidada para ser a Instrutora responsável pelo desenvolvimento da turma de alunos pois, já tinha feito a capacitação pedagógica através do INAMPS. A exemplo das profissionais anteriores, esta não tinha tido ainda nenhuma experiência com ensino e desenvolveu o PLE coordenando outras três enfermeiras. 
A entrevistada do DEPOIMENTO 6 pertencia inicialmente, à equipe de recursos humanos da região de saúde e depois, fixou-se no DS onde desempenhou a função de facilitadora da implantação do PLE. Teve ela a oportunidade de fazer a capacitação pedagógica na SES em 1985, com a equipe do MS e da OPAS e, além disso, desenvolveu a função de monitora de um outro curso de capacitação de enfermeiros envolvidos com as ações de atenção às DST/AIDS em outro município do Estado de São Paulo, curso esse, baseado na mesma proposta metodológica do PLE. Além disso, essa profissional desempenhou o papel de "apoio técnico" para algumas discussões desenvolvidas pelos alunos durante o curso de formação.

A última entrevistada DEPOIMENTO 7 desempenhou a função de Supervisora Técnica de Enfermagem de um hospital terciário de grande porte. Nesse nível gerencial, o seu envolvimento com o PLE foi o de propiciar as condições locais para que ele fosse desenvolvido. Havia um entendimento de que era um projeto da SMS; no quadro de pessoal do hospital quatrocentos atendentes de enfermagem necessitavam de formação, diante das exigências da nova Lei do Exercício Profissional que determinava prazo para a profissionalização daqueles trabalhadores. Essa profissional também representava a administração, na composição tripartite ${ }^{11}$ do conselho gestor daquele serviço.

\subsubsection{Quanto aos princípios e diretrizes do SUS}

As questões relativas às diretrizes descentralização e participação foram citadas com relevância em comparação às demais, por todas as entrevistadas dessa fase. As características das citações variaram desde a referência direta a uma destas categorias, até a exposição de sentimentos experimentados pelos profissionais instrutores e./ou alunos, como resultantes de experiências, da história daquela gestão, e/ou das estratégias metodológicas utilizadas no decorrer dos cursos.

A análise dos depoimentos também nos possibilitou compreender que a utilização de algumas estratégias metodológicas do PLE contribuíram de forma

\footnotetext{
${ }^{11}$ A composição tripartite era a forma de constituição dos conselhos populares, na saúde dos conselhos gestores das unidades, os quais tinham a representação dos usuários (50\%), os trabalhadores (25\%) e da administração (25\%).
} 
contundente para o desenvolvimento de práticas educativas na direção da integralidade da atenção à saúde da população, tendo por referência o seu contexto sócio-econômico e cultural.

\section{Descentralização}

A reorganização da SMS com a criação das ARS(s), dos DS(s) e hospitais de referência foi entendida, por quatro das entrevistadas, como uma questão de descentralização da gestão da saúde tanto política e administrativa, quanto assistencial.

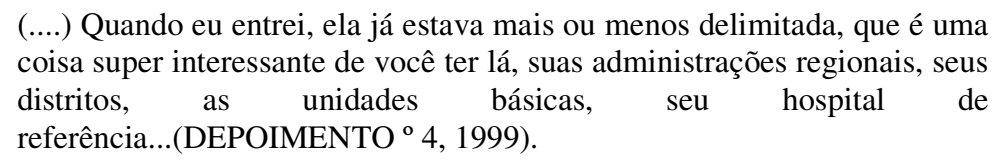

A municipalização dos serviços foi citada por uma das entrevistadas, como sendo a grande discussão política daquela gestão, e que representou, na opinião de uma outra profissional, o cumprimento do compromisso com a implantação do Sistema Único de Saúde no município de São Paulo.

O PLE foi entendido e citado, por três entrevistadas, como sendo uma decisão a ser implementada pelo nível regional portanto, de forma descentralizada.

Estavam tentando descentralizar o atendimento e a formação (DEPOIMENTO 5, 1999)

O projeto de formação de recursos humanos - na modalidade PLE - se configurou como uma das várias propostas implementadas com vistas à descentralização isto é, como uma proposta comprometida com a capacitação das equipes de trabalho, afim de viabilizar uma nova gestão em saúde. Ou seja, concordamos com a conceituação apresentada por Vieira $(1979$, p.67) citado por SAMPAIO e col. (1987, p.24) na qual a descentralização "consistiria num processo de natureza político-comportamental, pelo qual ocorrem redefinições nas relações 
entre centro e periferia, através da transferência significativa de poder, e cujo significado seria dar competência aos pontos mais afastados do centro, ampliando suas áreas de atuação através de iniciativas próprias locais".

Ao analisarmos os dados que retrataram o contexto em que o PLE se desenvolveu constatamos que duas das entrevistadas tiveram o entendimento de que havia uma política de RH estabelecida para valorizar o trabalhador e, portanto, o projeto de formação proposto no interior dessa política, teria essa finalidade e na opinião de uma delas,

contribuiria para a mudança de modelo, da visão de saúde (DEPOIMENTO 6, 1999).

Uma das citações explicita que o objetivo da formação era melhorar as condições para o trabalhador desenvolver o seu trabalho, de tal forma que ele pudesse ter uma visão real desse trabalho, pautada na diversidade da realidade em saúde, cujo entendimento excederia os limites daquelas tarefas que ele estava acostumado a desempenhar automaticamente propiciando-lhe então, uma consciência ampliada dessa prática.

O PLE era um instrumento para melhorar a qualidade do serviço em benefício dos usuários, da população. (....) eles passaram a ter uma outra visão, da própria comunidade, da importância da saúde pública (....) (DEPOMENTO 3, 1999).

Nossos resultados reforçam os dados obtidos no trabalho de TORRES (1994, p.126-7), cuja equipe de instrutores envolvida com a formação através do "Larga Escala" no município do Rio de Janeiro a partir de 1985, expôs o seu entendimento sobre a proposta de qualificação "que seria mais abrangente do que simplesmente ensinar a técnica mas, que exigia qualificar para o desempenho, para atender às necessidades do paciente". Ao considerar-se as "concepções e práticas, tanto o sujeito quanto o objeto parecem ter crescido de importância, ganharam abrangência, mais autonomia e algum nível de contextualização. Havia um desejo de que o servidor ao passar pelo processo tivesse uma 'visão ampliada', efetivo conhecimento da sua prática profissional o que lhe proporcionaria crescimento como ser humano: tanto o sujeito quanto o objeto humanizaram-se”. 
Naquele contexto político outras referências foram feitas na tentativa de resgatar os fatos isto é, houve quem se referiu a tantas coisas que aconteceram, houve quem se referiu a ocorrência de várias mudanças, vários projetos novos e houve quem pudesse citar as diversas mudanças referindo-se: ao atendimento préhospitalar; ao hospital aberto; ao grupo de combate à mortalidade materna e às lesões ao nascer; a vinda da cooperação italiana e ao estabelecimento dos territórios de saúde; ao diagnóstico de saúde; aos grupos de orientação (hipertensos, diabéticos). Todas essas questões integraram o desenvolvimento do projeto de formação porque diziam respeito a novas formas de trabalhar em saúde. Em todas as regiões de saúde, com algumas particularidades no desenvolvimento, essas novas práticas foram introduzidas e incorporadas aos conteúdos dos cursos de formação.

A incorporação dessas novas práticas de saúde nos conteúdos dos cursos de formação mostrou-se coerente com o projeto político de $\mathrm{RH}$ apresentado na pesquisa de MATTOS (1996, p.17) que reconheceu como uma das prioridades daquele projeto, "a formação do trabalhador aliada à realização do trabalho cotidiano em saúde. O trabalho é entendido enquanto processo de aprendizagem, de formação de sujeitos".

\section{Participação popular}

Todas as entrevistadas fizeram alguma referência à possibilidade de participar efetivamente de todos os processos de trabalho em saúde, naquele período em que os cursos de formação foram desenvolvidos.

Quando questionamos em relação ao contexto político, houve em uma das respostas uma valorização ao sentimento de liberdadel possibilidade de participação na condução do seu trabalho além, de reconhecer aquele contexto como sendo favorável e estimulante à participação dos profissionais de uma maneira geral, tanto a sua propriamente dita, quanto dos funcionários seus alunos, assim como da população usuária dos serviços. 
(....) e o que mais me impressionou assim, me deu mais vontade de trabalhar, abraçar a causa mesmo, foi a liberdade que a gente tinha de expressão, de trabalho, (....) com respeito...

foi uma abertura maior ...a própria população, uma participação maior da população, da comunidade...

a nossa grande conquista é o envolvimento da população, o envolvimento dos nossos alunos, dos nossos funcionários, a equipe que a gente estava trabalhando, eu acho que foi a melhor coisa na época... (DEPOIMENTO $3,1999)$.

Consideramos importante destacar o relato de uma outra entrevistada que reconheceu ser a municipalização a grande discussão política daquela gestão, tendo inclusive levado os alunos para participar de uma passeata.

A possibilidade de definir os critérios para a formação das turmas de alunos foi outro aspecto citado por duas das entrevistadas, como sendo uma decisão que contou com a participação de todos os envolvidos. A depoente de $n^{\circ} 4$ relatou-nos as dificuldades encontradas no seu local de trabalho para desenvolver o curso, apesar do consenso de que o PLE era uma decisão da SMS e portanto, não se justificaria a presença de tantos obstáculos. Foi necessário "brigar" para a adequação do local, para obtenção de materiais e equipamentos, entre outras coisas. Essa mesma profissional resgatou a decisão daquele distrito, de realizar uma visita das gestantes à maternidade do hospital de referência, promovendo dessa forma o reconhecimento do serviço que teriam o direito de usar.

A depoente $n^{\circ} 7$ também explicitou a sua preocupação, enquanto Supervisora Técnica,

em fazer com que todos os profissionais daquele local participassem das mudanças que estavam ocorrendo, dos projetos novos;

referiu-se a sua participação no conselho gestor daquele serviço, representando a administração e lembrou ainda, que os atendentes/alunos, num dado momento do curso, iam até as unidades básicas para observar o funcionamento das mesmas.

Quatro das entrevistadas referiram-se às estratégias metodológicas utilizadas nos cursos como instigantes para provocar um comportamento participativo mediante: a oportunidade da discussão, a possibilidade de apreensão por parte dos alunos das condições de vida e trabalho da população usuária, a consciência sobre as reais necessidades de saúde da comunidade e a importância da participação na 
busca da resolução dos problemas. A participação dos alunos, favorecida por essas estratégias (discussões, dramatizações, entrevistas com a população, visitas a campo, a apresentação do vídeo - Ilha das flores), concorreria para sedimentar a visão crítica da realidade, o compromisso com o trabalho e o respeito ao usuário.

(....) Então a proposta é que ele se relacionasse com a comunidade como ele participante daquele meio, aquela comunidade era dele também e, através disso, ele tomando essa consciência, ele passou a tratar melhor o usuário, a se sentir dentro daquele contexto porque o comum, era ele não se sentir dentro daquele contexto.

Esse conhecimento da realidade! (....) essa consciência a gente começou a ver, formando os alunos a gente começou a ver essa importância deles... estar passando para um vizinho que devia manter o ambiente limpo, os maridos se juntando em grupos para estar cuidando do local em que eles viviam, toda essa gente começou a ver, através do curso, que ..., a gente convidava os familiares para participar de determinadas discussões, para se ver o meio ambiente, para se ver o lugar limpo, para se ver o lugar sujo, então, para se ver os locais de lazer daquela comunidade, daquela região, e aí desenvolveu uma consciência de muitos! (DEPOIMENTO 6, 1999).

Segundo uma das entrevistadas, a oportunidade de discutir alguns temas no curso de formação tais como,

políticas de saúde, as condições de vida da população, a questão do controle social, a participação social, a implementação dos conselhos gestores e a possibilidade de fazer relações com o diagnóstico de saúde, a própria questão da territorialização,

questões que caminhavam paralelas ao PLE, assegurava a esses profissionais, alunos e instrutores, a condição de protagonistas desse processo no seu local de trabalho.

(....) Se eu tenho um atendente que ele está discutindo a importância de conhecer a área, a realidade local e tudo mais, quando chega esta questão pra ele, lá na unidade dele, ele fala "é isso aí mesmo gente" porque eu aprendi lá no curso que isso é importante, então assim, dele ser o protagonista desta história também, e ao mesmo tempo ele estar contribuindo mesmo que não tivesse essa percepção muito clara naquele momento, que o quê estava fazendo ele até ter essa contribuição diferenciada, era o fato dele estar lá fazendo o curso...(DEPOIMENTO 6, 1999).

A discussão efetuada por TORRES (1994, p.108-10) a respeito da proposta pedagógica do PLE, reconhece os "sujeitos do processo de trabalho, inseridos na geração de serviços de saúde, - realidade que articulava o ensino e a prática - como 
seres que necessitam que a qualificação profissional recupere a total organização e estrutura desse processo cujo objetivo é a construção de uma relação contextualizada entre sujeito e objeto, gerando a politização do conteúdo, sujeito e prática". As estratégias que utilizam discussões, teorizações, sistematização de princípios, concepções técnicas "promoverão a reflexão através do diálogo instrutor-aluno, aluno-aluno, aluno-instrutor-usuário, articulando o movimento do pensamento com a realidade, gerando um novo conhecimento e prática, tanto em termos do aluno, quanto do instrutor".

Assim posto, podemos reconhecer que a diretriz da participação teve estreita vinculação com os conteúdos e/ou estratégias dos cursos do PLE, ora estimulando a reflexão sobre vários aspectos da questão da saúde ora, verificando informações, condições de vida da população, ora analisando as condições dos serviços de saúde e/ou a postura dos profissionais. Concordamos com TELESI JUNIOR (1996, p.58) sobre o reconhecimento de que aquela gestão, “empreendeu inúmeros esforços para ampliar a consciência sanitária de cidadãos e funcionários dentro de um projeto maior de promoção da cidadania que possibilitaria aos funcionários e à população, interferir nos rumos da política de saúde do município”.

Além disso, podemos ainda reconhecer que o "projeto de formação enquanto um dos componentes do projeto político de $\mathrm{RH}$, colocava a necessidade do trabalhador participar de todo o processo de trabalho, desde o seu planejamento até a sua execução" apontando dessa forma para a perspectiva de emancipação do trabalhador (MATTOS 1996, p.17).

\section{口 Integralidade}

$\mathrm{Na}$ fase da coleta de dados, obtivemos quatro citações nas quais a questão da integralidade foi vinculada ao PLE. Duas das entrevistadas, quando expuseram o seu entendimento sobre a finalidade do projeto de formação, relacionaram-no com a proposta política que estava sendo implantada no município. Dessa forma, a formação nos moldes do PLE, significou 
ter uma visão de todo o sistema e de atendimento integral com participação, e para a outra, significou preparar para o novo sistema através da integração à comunidade (DEPOIMENTOS 3 e 5, 1999).

Numa outra citação, a entrevistada foi explícita ao referir-se ao PLE como tendo sido responsável por dar um salto na direção da integralidade, propondo uma assistência integral, humanizada e equânime. No momento em que procurou relacionar os conteúdos e estratégias metodológicas com as diretrizes, essa mesma profissional afirmou que o curso propiciou ao grupo, alunos e instrutores, conhecer a realidade de saúde-doença (morbi-mortalidade) da população. Complementou os dados referindo-se a participação de uma médica sanitarista, que fez o papel de "apoio técnico" na síntese das discussões realizadas pelo grupo de alunos a respeito de como vivem, adoecem e morrem as pessoas.

Uma outra profissional compartilha desse entendimento ao referir-se às estratégias metodológicas que levavam os alunos para dentro da realidade da comunidade, a qual, coincidentemente, era a mesma de muitos servidores. Então, conhecer essa realidade, de convivência do próprio aluno despertou a consciência de muitos para a importância da colaboração e, no nosso entender, propiciou-lhes um retrato mais fiel dos problemas e das necessidades de saúde da população a ser atendida.

As informações coletadas e que descreveremos a seguir nos permitiram ousar interpretações do material das entrevistas, para além do que eles diretamente puderam referir: 1) uma das instrutoras comentou que para a formação da turma de alunos, reuniu-se os atendentes do hospital e dos postos de saúde; 2) o curso ganhou reconhecimento dentro do local de trabalho, e por conseqüência, houve o envolvimento de outros profissionais da equipe de saúde - médicos, assistente social, psicologia - além, daqueles diretamente relacionados com as áreas em formação - a enfermagem e posteriormente a odontologia; 3) a visita propiciada às gestantes à maternidade na qual viriam a ter os seus filhos; 4) a visita dos alunos do hospital às unidades básicas de saúde para acompanhar o seu funcionamento.

Assim, pudemos compreender que houve um compromisso dos trabalhadores (Instrutores e Coordenadores) com a integralidade das ações, através da reunião das experiências dos alunos que procediam de unidades prestadoras de atenção primária, com um enfoque mais coletivo, e da unidade terciária cuja atenção é, 
preponderantemente, individual e, também, por utilizar os conhecimentos de vários profissionais da equipe de saúde, numa perspectiva multidisciplinar. Além disso, as estratégias metodológicas utilizadas no curso possibilitavam aos alunos raciocinar a partir de determinantes sociais como as condições de moradia, condições de higiene, de saneamento básico e não só através de um raciocínio unicausal e linear. Esta visão ampla segundo a entrevistada, possibilita ao aluno uma visão crítica do seu trabalho e solidária ao direito à saúde da população.

"Relações de solidariedade deveriam nortear o desenvolvimento das ações em saúde" (MATTOS 1996, p.18).

TELESI JUNIOR (1996, p.87-90) reconheceu na opinião de parte dos dirigentes entrevistados, que apesar do trabalho integrado ser diretriz de governo, a integração ficou resumida a ações episódicas e pontuais. Porém, no interior da Secretaria, parte dos entrevistados reconheceu a integração enquanto promotora do trabalho interdisciplinar. Para esse autor, "o trabalho coletivo, em equipe, fortalece a tese da integração, uma vez que são reforçadas as possibilidades de integração entre os diferentes saberes no vasto campo da saúde coletiva”.

Na análise realizada por TORRES (1994, p.142) quanto aos impactos do PLE sobre os atores envolvidos, as dificuldades e possibilidades desse processo 'em construção' a autora ressalta o fato de que, tradicionalmente, os processos de qualificação levam prioritariamente em consideração os profissionais de nível superior, enquanto que o PLE tem provocado igual impacto tanto nos níveis elementar e médio, quanto no superior envolvidos no programa, o que provoca um efeito maior sobre a "qualificação dos recursos humanos em saúde, aproximando os profissionais das diversas áreas, que normalmente trabalham de forma isolada".

\section{口 Equidade}

Apenas em uma das entrevistas, foi possível verificar a ocorrência de citações que vinculasse o princípio da equidade ao PLE. Uma das profissionais ao analisar a proposta de formação e a definição do seu público alvo, reconheceu que o PLE representou uma conquista das atendentes que até então nunca tinham sido contempladas com treinamentos ou cursos de capacitação ou formação profissional. 
(....) quando vinha papel de curso no nosso posto ou era pra médico, ou pra assistente social, ou psicólogo, nunca vinha nada pro atendente, a gente sempre foi colocada de lado, nunca teve curso de reciclagem nada! (DEPOIMENTO 4, 1999).

MATTOS (1996, p.127) ao contar a história da unidade de saúde através dos trabalhadores pesquisados, reitera essa opinião de que a "SMS não investia na capacitação profissional, voltada para as categorias de nível médio e auxiliar. No geral, as atividades de formação, desvinculadas da atuação em serviço, eram dirigidas para os trabalhadores de nível universitário".

Aquela mesma profissional, a depoente $n^{\circ} 4$, ao analisar o PLE e o contexto político no qual esteve inserido, afirma que aquele avançou ao propor assistência integral e equânime no sentido de não tratar todo mundo igual porque ninguém é igual.

Quando analisamos os dados, pudemos apreender pelo menos dois outros entendimentos a respeito da vinculação do desenvolvimento do projeto de formação ao princípio da equidade. Segundo a depoente $\mathrm{n}^{\mathrm{o}} 3$, a melhoria da qualidade do trabalho seria atingida através da formação, devido a coexistência no curso de algumas condições facilitadoras: a sua realização dentro do próprio horário de trabalho do aluno; a utilização das próprias unidades de serviço como locais de prática, evitando-se dessa forma o deslocamento do aluno para locais diferentes; o reconhecimento das suas experiências como ponto de partida para as suas reflexões, etc.

Numa outra entrevista, houve um relato a respeito do estranhamento que o desenvolvimento do curso provocou no próprio grupo de alunas. Elas questionavam quando iriam aprender (reaprender) as técnicas básicas da enfermagem, pois ficavam o tempo todo dedicando-se apenas à discussão. Apesar desse tipo de sentimento, o grupo gostava dessas experiências que permitiam um espaço de discussão pois, segundo a instrutora nunca tinha tido a oportunidade de estar discutindo....

No nosso entender, tais condições estabeleceram-se afim de garantir algum padrão de equidade ao propiciar uma formação efetiva aos alunos, que dificilmente teriam a oportunidade de se qualificar de uma outra forma. Significou reconhecer as diferenças estabelecidas nas relações de trabalho, que até então não haviam permitido a qualificação profissional para esse grupo. A estratégia metodológica 
adotada no projeto e reconhecida pela instrutora, valorizou as experiências que aquelas alunas traziam consigo para as salas de aula e reconheceu o direito delas em opinar, refletir, participar, deixando então de ser "simples executor[es] de tarefas".

\section{Universalidade}

Nos dados coletados, houve somente uma citação onde o PLE foi relacionado ao princípio da universalidade. A entrevistada em questão estava avaliando a efetividade do PLE, quando reconheceu o caráter democrático do processo de formação das turmas, o espírito de justiça ao priorizar quem não tinha tido a oportunidade de qualificação anterior e, a intenção universalizadora da proposta isto é, estava iniciando-se a formação de algumas pessoas mas, seria dada a oportunidade a todas.

(....) Mas acontece que a escolha das pessoas tinha sido um processo conjunto, bastante democrático, tinha sido decisão delas de se dar oportunidade pra quem não tinha tido nenhuma até então... E o nosso entendimento, que nós íamos começar com essas pessoas, que elas próprias escolheram para formar, e depois, em outro momento, formaríamos outras, até chegar a formar todo mundo. Todo mundo ia ter a mesma oportunidade, em outro momento...(DEPOIMENTO 4, 1999).

\section{CONSIDERAÇÕES FINAIS: MAIS PARA TÉCNICO DO QUE PARA POLÍTICO}

\subsection{Os princípios, as diretrizes do SUS e o PLE para o nível central}

A decisão política de formar as auxiliares de enfermagem configurou-se como um componente importante de uma política de recursos humanos para viabilizar o novo modelo de atenção à saúde, implantado no município de São Paulo, no período de 1989 - 1992.

A implementação do Sistema Único de Saúde no município exigiu a descentralização do gerenciamento das ações de saúde. O projeto de formação em 
larga escala, na condição de um forte componente desta política de RH, foi uma das atividades descentralizadas.

Desenvolver o PLE de uma maneira descentralizada significou capacitar as atendentes de enfermagem a desenvolver a prestação de serviços de saúde dirigidos para uma determinada realidade local, constituída pelas condições de vida e saúde de uma dada população e pela reordenação dos serviços de saúde que buscavam mudanças, incorporando profissionais e ações na perspectiva da atenção integral.

Um dos princípios desse projeto de formação foi o de considerar a prática profissional como a essência para a aprendizagem. Portanto, enfrentou o desafio de reconstruir o conhecimento - até então baseado apenas em técnicas assistenciais isoladas do contexto de trabalho no qual as atendentes se inseriam - para adotar um conhecimento baseado tanto na realidade das condições de vida da população quanto nas reformulações dos processos de trabalho. Tal processo demandou das alunas uma postura reflexiva, permeada pela observação, discernimento, ponderação, identificação e por fim, pela participação.

Essas características ou condições, é o que TORRES (1994, p.40), denominou na sua pesquisa de desenvolvimento da dimensão política do Programa de formação de trabalhadores de nível médio: significa preparar as pessoas que irão reconstruir a prática, tendo por norte os princípios que orientam o projeto político para o setor e por referência a reforma processual das condições sanitárias do país.

Assim posto, este projeto de formação, intermediado pelo contexto de diversas mudanças políticas e organizacionais, configurou-se como um instrumento, uma estratégia no sentido de buscar mudanças nas práticas dos serviços de saúde, em resposta aos requerimentos estabelecidos pelos princípios da reforma sanitária.

O PLE esteve portanto, vinculado às diretrizes do SUS, pois desenvolveu-se sustentado por práticas democráticas e comprometido com a qualificação de um contingente de pessoal apartado dessa condição. A capacitação resultante deste processo configurou-se como condição fundamental para o gerenciamento da saúde, na perspectiva da integralidade das ações, da universalidade do acesso da população e da qualidade da atenção à saúde da população. 


\subsection{Os princípios, as diretrizes do SUS e o PLE para o nível regional}

A compreensão das entrevistadas de que o PLE tratou-se da implementação de uma política de formação de recursos humanos para uma nova concepção em saúde, o novo modelo de atenção à saúde que se buscava implantar para o Sistema Único de Saúde, foi majoritária. Assim, a formação de pessoal auxiliar de enfermagem através do PLE configurou-se num instrumento para alcançar a melhoria da qualidade do serviço.

Quando analisamos o material por referência às diretrizes, especificamente, nota-se, no entanto, diferentes apreensões. Por referência à descentralização, observa-se que: ainda que, no nível central, o PLE tenha sido concebido no seu duplo caráter - técnico e político, no nível regional, ele foi entendido como sendo uma decisão de caráter técnico que requeria sua implementação descentralizadamente porém, o mesmo não foi entendido no seu caráter político, como sendo, ele próprio, uma atividade que deveria refletir a descentralização, advogando e disseminando o significado dessa diretriz.

\footnotetext{
(....) a gente estava mais envolvido com a parte da formação do profissional, do acompanhamento dele, da supervisão nos setores, então a parte mais geral, ficava mais distante, ficava mais a nível de outro profissional (....) (DEPOIMENTO 5, 1999).
}

TORRES (1994, p.16) ao discutir a dimensão política do Larga Escala, reconhece que em decorrência da "pouca politização", os atores separam o ponto de vista técnico do político, o que explica a visão de que a uma enfermeira-educadora caberia a "ação técnica" nesse processo, ficando a "ação política" para os cargos com tal perfil.

No contexto político no qual o PLE se desenvolveu, várias outras reformulações de caráter técnico-gerenciais foram implementadas. Essas propostas compreendiam uma rede complexa de decisões e inovações, que viriam a capacitar as equipes do nível local a gerir a assistência à saúde da população. Todas essas inovações foram incorporadas aos conteúdos dos cursos de formação. No entanto, somente a minoria das entrevistadas pode reconhecê-las como propostas de efetivação da descentralização. 
A diretriz da participação foi a que se mostrou mais relevante frente ao desenvolvimento do projeto de formação. Todas as entrevistadas reconhecem no desenvolvimento do PLE, a perspectiva da participação, que foi enfatizada, desde o processo de inserção dos alunos até a escolha das estratégias metodológicas que possibilitaram a reflexão, a identificação e a colaboração na perspectiva da realização de mudanças.

A segunda diretriz, fortemente relacionada aos conteúdos dos cursos do PLE, foi a da integralidade. De fato, houve um entendimento de que a associação de determinados conhecimentos à utilização de algumas estratégias metodológicas propiciariam uma visão ampliada da atenção à saúde e adequada às mudanças esperadas.

Particularmente, com relação a essas duas diretrizes, é possível constatar uma diferenciação de compreensão: de um lado, um entendimento predominantemente técnico e restrito e, de outro, uma compreensão ampliada no sentido de incoporar também o componente político. Nos pareceu então, que, para a maioria das entrevistadas deste estudo, não houve uma associação clara entre a proposta política do SUS - discriminada nas suas diretrizes - e o processo educativo escolhido para a formação das auxiliares. Em outras palavras, participar do processo educativo, das decisões de uma comunidade para resolver problemas de saúde ou ainda, dos projetos novos para entender as mudanças, não se configuraram como interesses políticos daquela gestão, expressos em termos das práticas democráticas e do incentivo ao controle social, no sentido de operacionalizar as diretrizes do SUS -.

Uma parcela significativamente menor das entrevistadas vinculou o princípio da equidade ao desenvolvimento do curso, reconhecendo como qualidade nesse projeto a proposição de tratamento desigual porque ninguém é igual e como justiça, a escolha das atendentes como público alvo, uma vez que elas jamais haviam tido oportunidade para qualificação antes do PLE.

A relação do PLE ao princípio da universalidade foi, minoritariamente, reconhecida pelo grupo das entrevistadas, apontando apenas, que o desenvolvimento dos cursos deveria assegurar o acesso de todas as atendentes ao longo do tempo. Não tivemos outra oportunidade no decorrer da coleta e/ou da análise dos dados, de 
constatar alguma referência a esse princípio frente ao objetivo final das mudanças na perspectiva da ampliação da cobertura assistencial da rede de serviços municipal.

As mudanças incorporadas aos processos de trabalho, estabelecidas naquela gestão, subsidiaram o desenvolvimento dos cursos de formação para a maioria das entrevistadas no entanto, ainda se considerarmos que as apreensões sobre o contexto político no qual o PLE foi implementado, mostraram-se diferentes para cada uma delas nesse nível regional, nem sempre foi possível estabelecer a correlação dessas propostas às diretrizes do SUS. Ousamos afirmar que a oportunidade de atuação direta no PLE possibilitou às instrutoras e coordenadoras um reconhecimento dessas mudanças que sustentavam a nova visão em saúde porém, foram pontuais as correlações entre as referidas mudanças, o projeto político da gestão e, particularmente, as características do projeto de formação na condição de instrumento a serviço da implantação do SUS.

Como limitação desta pesquisa, é preciso considerar as condições que possam ter prejudicado a coleta de dados: 1) a própria inexperiência da pesquisadora; 2) o tempo decorrido entre a implantação do PLE e a coleta de dados (cerca de dez anos).

Apesar dessas condições, acreditamos que a implantação do PLE no município de São Paulo, configurou-se como uma estratégia efetiva de formação de pessoal para o SUS em total consonância com as suas diretrizes políticas.

O estudo, sem dúvida nenhuma, acaba suscitando questões que podem ser objeto de novas pesquisas, na tentativa de explicar porque existiu um distanciamento entre o entendimento do nível central e o do nível regional. Pareceu-nos, evidente, que as capacitações pedagógicas e técnicas realizadas junto a esse quadro de profissionais, não foram suficientes para proporcionar - lhes a compreensão da dimensão política desse processo.

Os nossos resultados mostram-se muito semelhantes à análise efetuada por TORRES (1994, p.18) quando revela a "fascinação" experimentada pelo quadro de instrutores na Escola Técnica do Rio de Janeiro, com relação a "alternativa metodológica” proposta pelo Larga Escala. Ainda que a compreensão dessa proposta metodológica refira-se à prática profissional concreta - que envolve um projeto político de sociedade - "ocorre majoritariamente, [ uma redução ]da ação pedagógica aos meios isolando-a da sua ' dimensão política"'. 
Assim como TORRES (1994) temos que nos perguntar:

"Como contribuir efetivamente para as mudanças requeridas por um projeto político de construção de um sistema de saúde, sem termos clareza da dimensão política da ação pedagógica que desenvolvemos”?

Nesse processo de qualificação profissional os instrumentos pedagógicos contribuem para a construção de uma ação transformadora mediante a explicitação das contradições e o estímulo à reflexão (AZEVEDO 1992). A implementação da proposta pedagógica mediatizada pela prática profissional do setor saúde configurase como um elemento sinérgico para a instalação das mudanças necessárias ao projeto desse setor.

A vivência construída por esses agentes - trabalhadores do setor saúde possibilita a inter-relação de duas práticas sociais com grande potencial de transformação: a educação e a saúde (TORRES 1994; OLIVEIRA 1996).

A reorganização dos serviços de saúde só poderá ocorrer se houver uma efetiva participação dos diversos atores sociais. Esses atores - trabalhadores de saúde - deverão como cidadãos, estarem conscientes da prática social na qual estão inseridos, tanto aqueles de nível médio quanto os de nível superior. 


\section{REFERÊNCIAS BIBLIOGRÁFICAS}

Almeida ES. Contribuição à implantação do SUS: estudo do processo com a estratégia norma operacional básica 01/93. São Paulo; 1995. [ Tese de livre docência - Faculdade de Saúde Pública da USP ].

Almeida MCP. A situação da enfermagem nos anos 80. In: Anais do $41^{\circ}$ Congresso Brasileiro e Enfermagem; 1989 set 2-7; Florianópolis (SC):Universidade Federal de Santa Catarina; 1989.

Associação Paulista de Saúde Pública Debate A propósito da Reforma Sanitária; 1986 set 16; São Paulo.

Azevedo ML. Educação de trabalhadores da enfermagem com enfoque na pedagogia da problematização: avaliação de uma experiência no Rio de Janeiro. Rio de Janeiro; 1992. [ Dissertação de mestrado - Faculdade de Educação da UFRJ].

Bardin L. Análise de conteúdo. Trad. de LA Reto, A Pinheiro. Lisboa: Presses Universitaires de France /Edições 70; 1977.

Barreto Junior IF. Reforma do estado: uma análise do sistema único de saúde em São Paulo. São Paulo; 1999. [ Dissertação de mestrado - Pontifícia Universidade Católica].

Bertolozzi MR, Greco RM. As políticas de saúde no Brasil: reconstrução histórica e perspectivas atuais. Rev Esc Enf USP.1996;30: 380-98.

Bittar J organizador. O modo petista de governar. Teoria \& Debate 1992; (Caderno especial).

Bógus CM. A reforma sanitária e a educação continuada: a importância do investimento nos recursos humanos dos serviços locais de saúde. São Paulo; 1992. [Dissertação de mestrado - Faculdade de Saúde Pública da USP].

Bógus CM. A formação política e o fortalecimento da participação popular em saúde: o caso dos cursos de formação política de conselheiros de saúde do movimento de saúde da zona leste de São Paulo. São Paulo; 1997. [Tese de doutorado - Faculdade de Saúde Pública da USP].

Bordenave JED. A opção pedagógica pode ter conseqüências individuais e sociais importantes. Rev Educ AEC 1981; ( 41).

Brasil. Constituição: República Federativa do Brasil Brasília: DF, Centro Gráfico do Senado Federal; 1988. Cap. II: da Saúde. 
Brasil. Lei $\mathrm{n}^{\mathrm{o}}$ 7.498, de 25 de junho de 1986. Dispõe sobre a regulamentação do exercício da Enfermagem e dá outras providências. Documentos Básicos de Enfermagem, Conselho Regional de Enfermagem do Estado de São Paulo São Paulo, s/d.

Capistrano Filho D, Merhy EE, Campos WG, Bonfim JRA. O município e a saúde. São Paulo: Hucitec; 1992.

Carvalho GI, Santos L. Sistema Único de Saúde: comentários à lei orgânica da saúde (Leis 8080/90 e 8142/90). São Paulo: Hucitec; 1992.

Carvalho MR. Modelos assistenciais de unidades básicas de saúde e integralidade. Rio de Janeiro; 1991. [Dissertação de mestrado - Escola Nacional de Saúde Pública da FIOCRUZ].

Chiesa AM. A equidade como princípio norteador da identificação de necessidades relativas ao controle dos agravos respiratórios na infância. São Paulo; 1999.[ Tese de doutorado - Faculdade de Saúde Pública da USP].

Christófaro MAC. A organização do sistema educacional brasileiro e a formação na área de saúde. [ Documento elaborado através de consultoria ao Programa de Recursos Humanos da Representação da OPAS no Brasil]. Brasília, 1992.

Coêlho ABSR. Política de proteção à infância e adolescência e descentralização. Serv Soc Soc 1999;60:92-104.

Cohn A, Nunes E, Jacobi PR, Karsch US. A saúde como direito e como serviço. São Paulo: Cortez; 1991.

Cohn A. Descentralização, cidadania e saúde. São Paulo Perspect 1992; 6(4): 70-6.

Cohn A, Elias P, Jacobi P. Participação popular e gestão de serviços de saúde: um olhar sobre a experiência do município de São Paulo. Saúde Debate 1993; (38): 903.

Conselho Federal de Enfermagem / Associação Brasileira de Enfermagem. O exercício da enfermagem nas instituições de saúde do Brasil - 1982 - 1983 - 2 vols. Rio de Janeiro (RJ):COREn /ABEn; 1985.

Corvino MPF. A educação continuada de médicos nos serviços públicos de atenção primária a saúde. São Paulo; 1991. [Dissertação de mestrado - Faculdade de Saúde Pública da USP].

Coutinho CN. Representação de interesses, formulação de políticas e hegemonia. In: Teixeira SF, organizadora. Reforma sanitária em busca de uma teoria. São Paulo: Cortez; 1989. p.46-60. 
Coutinho, CN. Contra a corrente: ensaios sobre democracia e socialismo. São Paulo: Cortez; 2000.

Dâmaso R. Saber e práxis na reforma sanitária avaliação da prática científica no movimento sanitário. In: Teixeira SF, organizador. Reforma sanitária em busca de uma teoria. São Paulo: Cortez; 1989. p. 61-90.

Demo P. Participação é conquista: noções de política social participativa. São Paulo: Cortez; 1988.

Donato AF. Algumas considerações sobre as atuais tendências pedagógicas. São Paulo; s/d.

Elias PEM. Das propostas de descentralização da saúde ao SUS: as dimensões técnica e político-institucional. São Paulo; 1996. [ Tese de doutorado - Faculdade de Saúde Pública da USP].

Escola Nacional de Saúde Pública da Fundação Oswaldo Cruz. A política de recursos humanos em saúde no Brasil nos anos recentes. In: Médici AC, organizador. Recursos humanos em saúde. Rio de Janeiro: PEC/ENSP/ABRASCO; 1987. p.2436. (Textos de Apoio Planejamento, 1).

Escorel S. Saúde: uma questão nacional. In: Teixeira SF, organizador. Reforma sanitária em busca de uma teoria. São Paulo: Cortez; 1989. p. 181-92.

Gadotti M. Educação e compromissso. 2a ed. Campinas (SP): Papirus; 1986.

Gerschman S. A democracia inconclusa: um estudo da reforma sanitária brasileira. Rio de Janeiro: FIOCRUZ; 1995.

Giovanella L, Fleury S. Universalidade da atenção à saúde: acesso como categoria de análise. In: Eibenschutz C, organizador. Política de saúde: o público e o privado. Rio de Janeiro: FIOCRUZ; 1996. p.177-98.

Gomes R. A análise de dados em pesquisa qualitativa. In: Minayo MCS, organizadora, Delandes SF, Cruz Neto O, Gomes R. Pesquisa social: teoria, método e criatividade. Petrópolis (RJ): Vozes; 1994. p.67-80.

Heimann L, Carvalheiro JR, Donato AF, Ibanhes LC, Lobo EF, Pessoto UC. O município e a saúde. São Paulo: Hucitec; 1992.

Jacobi P. Políticas públicas e alternativas de inovação da gestão municipal: o complexo caso da cidade de São Paulo. São Paulo Perspect 1991; 5(2): 31-7.

Jacobi P. Estudo capitalista: transformações na dinâmica de intervenção e o papel das burocracias. In: Movimentos sociais e políticas públicas. São Paulo: Cortez; 1989.

Kadt E, Tasca R. Promovendo a equidade: um novo enfoque com base no setor da saúde. Trad. de AM Tijiwa. São Paulo: Hucitec; 1993.

Kowarick L, Singer A. A experiência do partido dos trabalhadores na prefeitura de São Paulo. Novos Estud CEBRAP 1993;(35): 195-216. 
Laurell AC, organizador. Estado e políticas sociais no neoliberalismo. São Paulo: Cortez; 1995.

Libâneo JC. Tendências Pedagógicas na prática escolar. Rev ANDES 1983; (6): 119.

Lucchesi G. Burocracia e política de saúde: arena ou ator? In: Teixeira SF, organizador. Reforma sanitária em busca de uma teoria. São Paulo: Cortez; 1989. p.157-79.

Ludke M, André MEDA. Pesquisa em educação: abordagens qualitativas. São Paulo: EPU; 1986. (Temas básicos de Educação e Ensino).

Luz MT. As Conferências Nacionais de Saúde e as políticas de saúde da década de 80. In: Guimarães R, Tavares RAW, organizadores. Saúde e sociedade no Brasil: anos 80. Rio de Janeiro: Relume Dumará; 1994. p. 130-52.

Mattos ML. Recursos humanos e o novo trabalhador em saúde: a experiência da Secretaria Municipal de Saúde na cidade de São Paulo durante a gestão do partido dos trabalhadores (1989 - 1992). Campinas; 1996. [ Dissertação de mestrado - Faculdade de Ciências Médicas da UNICAMP].

Médici AC, organizador. Recursos humanos em saúde. Rio de Janeiro: PEC/ENSP/ABRASCO; 1987. (Textos de Apoio Planejamento, I).

Melo C. Divisão social do trabalho e enfermagem. São Paulo: Cortez; 1986.

Mendes EV. Distrito sanitário: o processo social de mudança das práticas sanitárias do Sistema Único de Saúde. São Paulo: Hucitec/Rio de Janeiro: ABRASCO; 1993.

Minayo MC de S. O desafio do conhecimento: pesquisa qualitativa em saúde. $3^{\text {a }}$ ed. São Paulo: Hucitec / Rio de Janeiro: - ABRASCO; 1994.

Ministério da Saúde. RH SUS política de recursos humanos para o SUS: prioridades e diretrizes para a ação do Ministério da Saúde. Brasília: (DF) Coordenação Geral de Desenvolvimento de Recursos Humanos para o SUS; s/d.

Ministério da Saúde Recursos humanos para serviços básicos de saúde: formação de pessoal de níveis médio e elementar pelas instituições de saúde. Brasília: (DF) Centro de Documentação do Ministério da Saúde; 1982.

Ministério da Saúde. Responsabilidades institucionais no desenvolvimento do Projeto “Larga Escala”. Brasília: (DF) Grupo Assessor Principal; 1983.

Ministério da Saúde. Sistema Único de Saúde Diretrizes para formulação de política de recursos humanos. Brasília: (DF) Secretaria Geral; 1989.

Ministério da Saúde. Projeto de profissionalização dos trabalhadores da área de enfermagem - PROFAE. [ Guia online] 2000; Disponível em < URL: http.//www.saúde.gov.br/profae/guia. htm. [2000 ago]. 
Noca CRS. O atendente e o processo de profissionalização da enfermagem: um estudo nos hospitais no município de São Paulo. São Paulo, 1999. [Dissertação de mestrado - Faculdade de Saúde Pública da USP].

Oliveira Junior M. Administração de recursos humanos um obstáculo à municipalização dos serviços de saúde? Saúde Debate 1990; (28): p.41-5.

Oliveira LSS. A profissionalização dos trabalhadores de enfermagem nos serviços de saúde: uma experiência de construção do Projeto Larga Escala na cidade de São Paulo. São Paulo; 1996. [Dissertação de mestrado - Faculdade de Saúde Pública da USP].

Paim JS. Recursos humanos em saúde no Brasil: problemas crônicos e desafios agudos. São Paulo: Faculdade de Saúde Pública/USP; 1994.

Paiva MS, coordenadora, Oliveira IRS, Araújo MJS, Carvalho V, Santos I. Enfermagem brasileira: contribuição da ABEn. Brasília: ABEn Nacional; 1999.

Parlett M, Hamilton D. Avaliação iluminativa: uma nova abordagem no estudo de programas inovadores. In: Goldberg, MAA, Souza CP de, organizadoras. Avaliação de programas educacionais: vicissitudes, controvérsias e desafios. São Paulo: EPU; 1982. p.38-49.

Payne SL. The art of asking questions. Princeton University Press Princeton. New Jersey EUA; 1951.

Peduzzi M. Capacitação de pessoal auxiliar em saúde mental: reflexões a partir da experiência de um Centro de Saúde Escola. Saúde Debate 1992; (36): 67-72.

Pelicioni MCF. Serviços de saúde: utilização e opinião dos usuários. São Paulo; 1989.[ Dissertação de mestrado - Faculdade de Saúde Pública da USP]

Pinto JB. Ação educativa através de um método participativo no setor saúde. Recife; Universidade Federal de Pernambuco; s/d.

Poulantzas N. O Estado, o poder e o socialismo. Rio de Janeiro: Graal; 1980.

Poz MR Dal, Varella TC. Recursos humanos em saúde no Brasil: política e problemas. In: Guimarães R, Tavares RAW, organizadores. Saúde e sociedade no Brasil: anos 80. Rio de Janeiro: Relume Dumará; 1994. p.193-207.

Rosas EJ. A extensão de cobertura dos serviços de saúde no Brasil: PIASS, análise de uma experiência. Rio de Janeiro; 1981. [Dissertação de mestrado Escola Nacional de Saúde Pública da FIOCRUZ].

Sader E. Governar para todos um avaliação da gestão Luiza Erundina. São Paulo: Página Aberta; 1992.

Sampaio GM, Parente LI, Wohland M. Uma experiência de descentralização em administração pública. Cad FUNDAP 1987; (13): 23-6.

Santana JP. Formulação de políticas de RH nos serviços de saúde. Saúde Debate 1990; (28): 66-71. 
Santos I, Souza AA, Vieira TCV. Preparação de pessoal pelas instituições de saúde. Brasília (DF); 1987.

Santos I, Souza AA. Formação de pessoal de nível médio pelas instituição de saúde: projeto larga escala, uma experiência em construção. Saúde Debate 1989: 61-4.

Santos I, Souza AMA, Galvão EA. Subsídios para a formulação de uma política de profissionalização para o pessoal de enfermagem, sem qualificação específica, empregado no setor saúde - Brasil. Educ Med Salud 1988; 22: 201-10.

São Paulo (Cidade). Decreto n.28.625, de 30 de março de 1990. Cria o Centro de Formação dos Trabalhadores da Saúde - CEFOR, e dá outras providências. Diário oficial do Município de São Paulo, São Paulo, mar. 1990. p.1.

Saviani D. Escola e democracia: teorias da educação, curvatura da vara, onze teses sobre educação e política. 31 ed. Campinas (SP): Autores Associados; 1997. (Coleção polêmicas do nosso tempo; v.5).

Schraiber LB; Peduzzi M. Tendências e possibilidades da investigação de recursos humanos em saúde no Brasil. Educ Med Salud 1993; 27 (3): 295-313.

Secretaria Municipal da Saúde. Proposta de formação de pessoal de níveis elementares e médio na Secretaria Municipal de Saúde. São Paulo: 1989.

Secretaria Municipal de Saúde. Formação de pessoal de nível médio na SMS de São Paulo o período de 1989 - 1992. São Paulo: Centro de Recursos Humanos Centro de Formação dos trabalhadores da saúde; 1993.

Silva JA. Coordenação Geral de Desenvolvimento de Recursos Humanos para o SUS. Ministério da Saúde. Ofício Circular CGDRH/SUS/MS/ n 061, 1992

Silva JA. Desarrollo de recursos humanos para los sistemas locales de salude: Brasil. Educ Med Salud 1993; 27:32-49.

Silva ZP. O município e a descentralização da saúde. São Paulo Perspec 1996; ( $\left.1^{\circ}\right): 81-7$.

Simioni AMC, Atique N. Recursos humanos e municipalização: notas sobre o panorama legal. Saúde Soc 1993; 2: 75-91.

Singer P. Um governo de esquerda para todos: Luiza Erundina na prefeitura de São Paulo (1989 - 1992). São Paulo: Brasiliense; 1996.

Síntese do Relatório Final da $\mathbf{1}^{a}$ Conferência Nacional de Recursos Humanos 1986; Brasília (DF).

Sposati A, organizadora. Que cidade é esta? Mapa da exclusão/inclusão da Cidade de São Paulo, Região Leste 1. São Paulo: Núcleo de Estudos e Pesquisas sobre Seguridade e Assistência Social - PUC-SP; s/d.

Teixeira CF. Formação de recursos humanos para o SUS desafios na perspectiva da mudança do modelo de gestão e atenção à saúde. Saúde Debate 1993; (41): 20-3. 
Teixeira SF, Mendonça MH. Reformas sanitárias na Itália e no Brasil: comparações. In: Teixeira SF, organizador. Reforma sanitária: em busca de uma teoria. São Paulo: Cortez; 1989. p.193-232.

Teixeira SF, organizador. Reforma sanitária em busca de uma teoria. São Paulo: Cortez; 1989.

Teixeira SMF. Política de saúde na transição conservadora. Saúde Debate 1989; (26): 42-53.

Telesi Junior E. Reflexões sobre a política de saúde do Município de São Paulo (1989 - 1992). São Paulo; 1998. [ Tese de doutorado - Faculdade de Saúde Pública da USP].

Torres MNFB. Qualificação e trabalho em saúde o desafio de "ir além" na formação dos “trabalhadores” de nível médio. Rio de Janeiro; 1994. [Dissertação de mestrado - Faculdade de Educação da UFRJ].

Valla VV, Stotz EN. Participação popular e saúde. Petrópolis: CDDH/CEPEL;1989.

Vieira ALS. Formação do atendente de enfermagem no Brasil: um desafio. Cad Saúde Pública 1990; 6: 62-73.

Vieira TCV, Scucato R. Formação de pessoal auxiliar para enfermagem nos serviços de saúde: Brasil. Educ Med Salud 1988; 22:35-46.

Universidade de São Paulo - Faculdade de Saúde Pública. Biblioteca /CIR. Guia de apresentação de teses. São Paulo; A Biblioteca; 1998.

Westphal MF, PELICIONI MCF. Contribuição da educação em saúde para a reforma sanitária. Saúde Debate 1991; (33): 68-73. 
ANEXOS 


\section{ANEXO 1 \\ CONTEÚDO CURRICULAR DO CURSO DE AUXILIAR DE ENFERMAGEM \\ PLE - CEFOR \\ 1989-1992 \\ ÁREA I \\ Unidades I,II,III,IV,IV}

A análise dos documentos e das entrevistas (nível central e regional) seguiram os encaminhamentos de uma análise temática. A análise temática foi realizada de acordo com as orientações de (BARDIN 1977, p.105) que vê o tema 